\title{
Quiring in Manuscripts of the Late Middle Ages
}

\section{Introduction}

Over the last few decades, ever increasing attention has been paid to the codex's various material characteristics. Codicology, which is to say 'la discipline qui étudie le livre manuscrit en tant qu'objet matériel', has produced noteworthy results in a number of areas. ${ }^{1}$ In the present contribution, we would like to address a particular aspect, namely the structure of the quire, ${ }^{2}$ whose importance in the domain of the archaeology of the book should not be overlooked. Indeed, every codex is the product of an ensemble of elements which are closely correlated, and therefore the choice of a particular type of quire is inevitably linked to other constituent parts of the manuscript-the writing support being the most obvious one.

In reality, the study of quiring can be pursued in order to fulfil a number of different aims. These may lie within the ambit of wide-ranging research and be focused on the history of the codex in general, or instead on a certain type of manuscript. ${ }^{3}$ Alternatively, the study of quiring may constitute the subject of an ad hoc analysis aimed at investigating the composition of quires in specific

Translated from the Italian into English by Mark Livesey. Original published as Busonero, Paola (1999), 'La fascicolazione del manoscritto nel basso medioevo', in Busonero, Paola / Casagrande Mazzoli, Maria Antonietta / Devoti, Luciana / Ornato, Ezio, La fabbrica del codice. Materiali per la storia del libro nel tardo medioevo, Roma: Viella (I libri di Viella, 14), 31-139.

This research was originally envisaged as a specialisation thesis at the 'Scuola di specializzazione per conservatori di beni archivistici e librari della civiltà monastica' at the University of Cassino (April 1995). Particular thanks are due to Ezio Ornato, who oversaw the planning and preparation of this work, and to Marco Palma, who inspired its conception and followed its realisation at every step of the way.

1 For a status quaestionis on codicological studies, see Derolez 1995, passim.

2 Here, we do not wish to enter into the lively debate as to whether the bifolium or the quire represents the basic 'building block' of the codex. For an overview of the topic, see Zappella 1994, 17-54 passim.

3 Turner 1997, 55-71; Derolez 1984, I, 33-39.

Ә Open Access. (c) 2022 Paola Busonero, published by De Gruyter. (c))BY-NC-ND This work is licensed under the Creative Commons Attribution-NonCommercial-NoDerivatives 4.0 International License. https://doi.org/10.1515/9783110743838-008 
manuscripts whose origin and date are known; on the other hand, it may be part of research focused on the construction of the quire itself. ${ }^{4}$ In many instances, the structure of a codex is studied primarily with the aim of solving problems in relation to textual tradition.

Before providing some basic information on the development of quiring from the birth of the codex up until the $12^{\text {th }}$ century, so as to acquaint ourselves with the period that will be the focus of this contribution, it will be useful to mention some works dedicated to the quire viewed as a material product, and therefore as a manufactured object which came into being as a result of a series of carefully considered technical choices. The first research initiatives carried out in this area are closely associated with Léon Gilissen, who proposed a theoretical quire construction technique consisting in the folding of skins. Simply stated, the scholar held the opinion that the quaternion, which is the gathering most commonly observed in parchment codices, derives from a single skin folded thrice so as to create an in-octavo format, or from two skins each folded twice to create an in-quarto format. ${ }^{5}$ Providing evidence for the initial solidarity of the skin were, supposedly, various irregularities (also present in non-contiguous leaves), such as striations and holes, etc., the observation of which should make it possible to ascertain the way in which the skins were worked and folded so as to create the quire.

As Bozzolo and Ornato have shown, such a hypothesis regarding the prefolding of skins is not only logical but also entirely compatible with the trend in size and proportion seen in Latin codices, ${ }^{6}$ which 'vary in such a way so as to present average values that largely speaking correspond to the variations in height and width produced in the original unit of writing support after successive folding'?

The sequence of steps by means of which one can produce a quire according to Gilissen's reconstruction was subjected to scientific verification by Piero Bozzacchi and Marco Palma, ${ }^{8}$ who in it exposed a number of weaknesses. Assuming to be valid the fundamental proposition that a quire is formed from a

4 Bozzolo / Ornato 1980, 123-212 ('La constitution des cahiers dans les manuscrits en papier d'origine française et le problème de imposition'); Gilissen 1977, passim; Bozzacchi / Palma 1985.

5 Gilissen outlines four folding possibilities for the in-octavo types, to which an equal number of formulas correspond, and two for the in-quarto types, formulas $\mathrm{A}^{2}$ and $\mathrm{C}^{2}$.

6 Bozzolo / Ornato 1980, 215-351 passim.

7 Bozzacchi / Palma 1985, 328.

8 Bozzacchi / Palma 1985, 325-336. 
pair of skins, ${ }^{9}$ the two scholars hypothesised that the sequence of steps deemed to be the most natural with respect to those imagined by Gilissen was preceded by the cutting of the parchment ${ }^{10}$-in a perpendicular direction along its main axis-so as to immediately obtain two bifolia. This expedient, whilst respecting the formula proposed by Gilissen, would also make it possible to carry out with greater ease the steps required to prepare the quire to receive script (i.e. ruling and pricking).

A series of studies by Frank M. Bischoff ${ }^{11}$, which will be discussed in due course in the current contribution, is dedicated to parchment as a constituent element of the quire; as such, parchment is closely linked to the qualitative choices made during the manufacture of a volume. These choices will also be examined in the present contribution. Bischoff, in collaboration with Marilena Maniaci, has also recently undertaken an investigation of the dimensions of skins and the formats derived from them, and of the folding methods which lead to the formation of quires. ${ }^{12}$

Up to this point, we have spoken of the archaeology of the quire from an experimental perspective, but in order to set the study of quiring within a historical context we will have to refer to the research carried out by Bozzolo and Ornato, who were the first scholars to examine the variability of quire formation from a quantitative perspective by linking it to other parameters. We have already mentioned their contribution to the validation of the hypothesis as regards skin folding for the construction of quires, but it should be added that the same verification procedure was also applied to paper manuscripts. ${ }^{13}$ Indeed, the two scholars carried out an ad hoc study of the making of quires in French paper codices, the results of which will be examined later on in the section dedicated to the relationship between quire formation and book format. ${ }^{14}$

An attempt to form an overview of the development of quiring from the birth of the codex up until the Late Middle Ages can certainly adopt as its starting point, with respect to the first centuries of manuscript production, Eric Turner's observations. It is to him that we owe, as part of the vast amount of

9 The verification was carried out using Gilissen's formula $\mathrm{A}^{2}$, which relates to the in-quarto types.

10 According to Gilissen, the leaves were delivered to the scribe either one at a time or progressively, depending on his need for them during the copying process, or even at the time of binding, if the quire was copied using the 'imposition' method. See Gilissen 1977, 15-41.

11 Bischoff 1991; Bischoff 1994; Bischoff 1993.

12 Bischoff / Maniaci 1995.

13 Bozzolo / Ornato 1980, 254-263.

14 Bozzolo / Ornato 1980, 123-212. 
research on the oldest papyrus and parchment codices, a picture of the various types of quiring employed in the period extending from the $2^{\text {nd }}$ to $6^{\text {th }}$ centuries CE.

From this overall picture one can infer the extent to which the choice of quaternions was favoured from the earliest times. We can count 14 examples in papyrus and 8 in parchment, even if quinions 'are in the early period a strong rival to fours', ${ }^{15}$ with 8 examples in papyrus, and 3 in parchment, whilst senions start to appear from the $3^{\text {rd }}$ century CE onwards. According to Turner, at a certain point in time the quaternion became the standard structure in the manufacture of codices $^{16}$, to the extent that almost all the codices dating from the $4^{\text {th }}$ to $6^{\text {th }}$ centuries included in the CLA (Codices Latini Antiquiores) ${ }^{17}$ lists are composed of quaternions. However, this predominance manifests itself over an extended period of time: in fact, based on Turner's data, no codex structured entirely in quaternions emerges before the $4^{\text {th }}$ century CE.

In actual fact, Lowe, in the introduction to the first volume of the $C L A,{ }^{18}$ where he provides some information on the categories that appear in the descriptions of codices, affirms that, for the period he studied, the quaternion represents the rule. The quinion is seen in only a few very ancient classical codices, ${ }^{19}$ and in codices originating from insular production centres. ${ }^{20}$

For our part, we carried out a perusal of the CLA listings, with the aim of determining the number of codices that present with structures other than the quaternion: 36 examples formed from quinions were found, and 6 from senions.

To these we can add 23 codices which are mostly formed of quaternions, but in which quinions and senions also appear (or both), and 20 codices that do not contain a predominant type of quire structure, but which in the bulk of cases contain both quaternions and quinions. As is plain to see, apart from a certain number of instances in which quinions present in the majority (as has already been mentioned), and except for some very ancient codices, or ones which originate from the insular context, the overall picture is rather uniform, with a struc-

15 Turner 1977, 62. According to Colette Sirat, a link may exist between the use of papyrus and the structuring of codices in quinions. On this subject, see Sirat 1998, passim.

16 In fact, the word quaternion would be assigned the generic definition 'quire'. In the $15^{\text {th }}$ century, on the other hand, the humanists used the terms quaternion, quaternus, quinternio, quinternus and sexternus indiscriminately to mean 'quire'. See Rizzo 1973, 42-47.

17 An overview of the exceptions to quiring in quaternions that appear in the CLA will be provided in due course.

18 Lowe, CLA I, p. X.

19 Lowe, CLA I 12, 74, 115.

20 Lowe, CLA I 78, 87. 
ture based on quaternions proving overwhelmingly to be the most widely adopted one.

Jean Vézin's observations, which can be read in his essay of 1978 on La réalisation matérielle des manuscrits latins pendant le haut Moyen Âge, are largely speaking in agreement with what has been stated up to this point. In particular, regarding senions, the scholar makes it clear that this type of quire was frequently adopted from the $13^{\text {th }}$ century onwards, attributing the increase in the number of leaves per quire-reaching twenty-four, in the case of Bibles-to the use of parchment which was thinner and less rigid. ${ }^{21}$ Quaternions, on the other hand, would continue to be used even in the printed book.

The history of the manufacture of the codex from the $9^{\text {th }}$ to $11^{\text {th }}$ centuries - at least with respect to the question of quiring-does not seem to present any radical changes. As regards the end of Early Middle Ages, we can adopt as a foundation the information that emerged in La structure matérielle du codex dans les principales aires culturelles de l'Italie $d u X^{e}$ siècle, a research initiative aimed at investigating the material characteristics of codices produced in Italy in the $11^{\text {th }}$ century. In a sample composed of 326 codices (11 Atlantic Bibles, 100 Beneventan manuscripts, 94 Carolingian, 61 Greek, and 60 volumes in so-called 'romanesca' script), the quaternion proves to be the rule in $95.06 \%$ of cases, with no appreciable differences between one group and another, or within sub-groupscreated by subdividing the overall sample based on certain characteristics, such as size, thickness, and so on. ${ }^{22}$

In order to obtain a further glimpse of the situation as it was in the $11^{\text {th }}$ and $12^{\text {th }}$ centuries, the latter being the so-called 'Renaissance century', ${ }^{23}$ still in relation to the manufacturing choices that prevailed in codex production, it will be useful to refer to Birger Munk Olsen's well-known work L'étude des auteurs classiques latins aux $X I^{e}$ et $X I I^{e}$ siècles for the period in question. His review, besides offering a highly pertinent reference point for those wishing to carry out philological studies, enables one to gather information about the physical characteristics of the codices, since each of them-either fully or partially, as the case may be-is provided with a codicological description. In the present con-

21 These notions were briefly revisited in Vézin 1998, 99-100.

22 Bianchi et al. 1993b, 412-413.

23 Haskins 1972, passim. In the $12^{\text {th }}$ century, among the large number and multifarious aspects that characterised the flowering of culture were the revival and development of an interest in the Latin classics (though it should be acknowledged here that the true rediscovery of classical heritage occurred in the $11^{\text {th }}$ century), resulting in a remarkably high production of manuscripts, which Munk Olsen provides a detailed panorama of in his work (Munk Olsen 1982-1989). 
text, we should emphasise the fact that the vast majority of manuscripts described are composed of quaternions.

Now that these initial observations have been made, we have almost arrived at the threshold of what will be the domain of the present contribution. The overall picture of manufacturing techniques used in books appears to be fairly uniform throughout the entire $12^{\text {th }}$ century, even if the said period is particularly rich in cultural stimuli and presents new facies with respect to the institutions involved in the oversight of high culture. In fact, over the course of the $12^{\text {th }}$ century, a revolution in education and the organisation of knowledge took place which saw the emergence of the first universities, and therefore the shifting-so to speak-of the scriptoria from the monasteries to the cities. This change saw its most tangible results in the $13^{\text {th }}$ century, the moment a decisive crossroads was reached in the production and use of knowledge. Also seen were considerable changes in the preparation and manufacturing techniques used in the codex: one has only to think of the pecia system to get an idea of the innovations that occurred. The book increasingly became an indispensable work tool; hence it was produced using methods that were very different from those employed in the Early Middle Ages.

The new significance taken on by the codex and the modifications that this brought to its various components-be they textual, graphic or material ${ }^{24}$-have been amply studied from many different points of view. During the course of the present contribution, we shall seek to deepen our knowledge of quiring, a rather particular aspect of the codex which is perhaps somewhat peripheral, but not entirely secondary, inasmuch as it exerts an impact on the way the manufactured object-book presents. Anyone with an interest in the archaeology of the book will certainly be aware of how, in the $13^{\text {th }}$ and $14^{\text {th }}$ centuries, the structure of the codex underwent various changes. Indeed, side-by-side with quaternions, different types of quire appear, such as quinions and senions-although the quinion proves to be indissolubly linked to the humanistic codex of the $15^{\text {th }}$ century. ${ }^{25}$ Other forms appear too. In fact, in various studies-not least in those which we have just taken a look at-it is possible to find some indications regarding the manufacture of codices in the Late Middle Ages or, more particularly, the quiring of a certain type of manuscript. However, what appears to be lacking is an overall picture of the phenomenon that takes into account the evolution of quiring in relation to the various countries of Europe, ${ }^{26}$ and also in

24 Le Goff 1979, 87-90.

25 Derolez 1984, I, 33-39.

26 The investigation chiefly covered England, France, Italy, Germany and the Low Countries. 
relation to the codex's other components. Therefore, starting out from these observations, we have posed the following questions:

a. What was the make-up of the quiring 'landscape' in Europe starting from the end of the $12^{\text {th }}$ century and extending up until the end of the $15^{\text {th }}$ ?

b. When and where-in other words, in which countries-did the shift from quaternions to other types of quires occur? And why did it occur? ${ }^{27}$

c. What was the role played by some widely employed typologies, such as quinions and senions?

d. Does quiring interact-and to what extent-with specific variables, such as the support, textual typology, and others?

To answer such questions, it was necessary to base our research on a rather large sample of manuscripts-indeed, the largest sample possible, so as to be able to obtain a sufficiently broad view of the situation, both synchronically and diachronically. Accordingly, the method that seemed most appropriate to employ in order to fulfil the requirements of the present contribution was the quantitative one, given its particular degree of adaptability when working with large corpora, even if the subject of the present research is best known from the qualitative standpoint. ${ }^{28}$ In fact, the analysis that will be carried out here does not call for the use of well-known statistical parameters, ${ }^{29}$ which broadly speaking form the basis of quantitative analyses. ${ }^{30}$

\subsection{Description of the corpus. Choice of variables. Database design}

Given the broad scope of the investigation, it is obvious that the corpus of manuscripts to be examined would potentially have to include all the parchment or paper codices produced in England, France, Italy, Germany and the Low Countries between the mid- $12^{\text {th }}$ and $15^{\text {th }}$ centuries. ${ }^{31}$ Such a sample-which can only

27 Concerning this issue, see Derolez 1995, 377.

28 Even if one is still dealing with a quantity: in other words, the number of bifolia that make up a quire.

29 The distribution of the frequency, the average, the variance, etc.

30 In fact, in order to work in the field of quantitative codicology it is not sufficient merely to apply statistical methods or to use particularly large samples. Regarding the notion of quantitative codicology, the purposes to which it is put, and the methods employed, see Ornato 1997, passim.

31 This topic has already been addressed by Busonero in Busonero 1995, passim. 
be conceived of in theory-is out of the reach of an individual researcher who wishes to carry out his or her inquiry within an acceptable length of time. Therefore, in order to combine the need to provide answers to the questions posed above (without renouncing the possibility of working on a sufficiently large and representative corpus, since only one of this kind is suitable for our purposes), and to make it possible to contain the work within a reasonable timeframe, it was necessary to make use of 'second-hand' data-that is to say information gleaned from manuscript catalogues.

In truth, foregoing the possibility of scrutinising the relevant material was not easy to accept without feeling a certain amount of regret, since only a de visu examination of the codices would make it possible to guarantee the disclosure of 'all the variables considered pertinent to the research, based on an unambiguous surveying protocol established in advance', ${ }^{32}$ so as to obtain a sample of uniform and compatible data. Therefore, in this initial phase of the study the decision was made to forego investigating the phenomenon in the most complete and exhaustive way. Instead, it was decided to collect all the details which seemed, at the outset, to be noteworthy, with the goal of building a comprehensive overview of the situation to serve as a background for all further hypotheses or in-depth analyses.

Once the 'catalogue' option had been embraced as the only feasible way of identifying and analysing a sufficiently large, and at the same time accessible sample of manuscripts, the second step consisted in the selection of the sources to sort through. The sorting process was based on the prerequisite of identifying the variables that were considered indispensable-or at least useful-to the research, since the choice could only be based on the presence or absence of these.

The discriminating criterion initially applied to identify useable material was, needless to say, information on quiring, either expressed in a complete form (i.e. through the provision of information on each constituent quire type present in the codex), or by specifying the predominant quire type.

Following an initial survey carried out on a few hundred volumes, approximately 190 catalogues emerged which met the aforementioned essential prerequisite. ${ }^{33}$ How, then, could this number be further whittled down to arrive at a

32 See Busonero 1995, 13.

33 The reader should note that since 1994 (the year in which data collection was completed) the number of available printed catalogues has greatly increased, and therefore also the possibility of identifying suitable material for this type of research. To provide an example, we can cite Clairvaux's catalogue, in which it was possible to consult, in draft form, the codicological descriptions of volumes listed under the letters, C, F, I, thanks to the acquiescence of the authors. 
definitive corpus to focus on? Clearly, the basic precept for achieving this goal consisted exclusively in assessing the richness (greater or lesser) of the catalogue descriptions with respect to the information considered indispensable, or at least relevant, to the present investigation-in other words, with respect to the variables it was presumed might usefully be correlated to quiring.

This consideration naturally implies the need to devise a survey form to gather all the variables in question, and the drafting of an examination protocol which determines the way in which data is collected. As we have already pointed out, a codex represents a combination of elements which are intimately connected to each other, and therefore one should not-in the first place, at leastneglect or omit any parameter, given that all of them could potentially interact with a volume's quiring. Therefore, it was decided to include in the datasheet the largest possible number of variables, compatible, of course, with the type of information that one can reasonably expect to find in a catalogue (in the sense that a characteristic like pricking might seem to be of great interest, but the possibility of investigating it in the absence of a first-hand examination of the item would be virtually nil).

Needless to say, among the variables there exists a hierarchy of importance. Therefore, along with information on quiring, it was considered indispensable that the catalogues should furnish information on both the codex's country of origin and a dating accurate to within, at minimum, half a century. ${ }^{34}$

In theory, the development of a survey form and an appropriate surveying protocol might on first consideration seem like a task that should not present many problems. However, in our case it turned out to be a rather complicated proposition, to the extent that, despite having attempted to foresee all the possible scenarios, it proved necessary to make adjustments and revisions as the work progressed.

Here, we present a summarised version of the variables covered by the survey form (the reader can find a completed specimen form and the surveying protocol in the Appendices attached to this contribution). ${ }^{35}$

34 Initially, it was thought that it would be enough to date works to within a century, but it was soon realised that this would make it impossible to track the evolution of quiring in a sufficiently precise way. On the other hand, one obviously cannot expect that all datings in a catalogue be accurate to within half a century; rather, the basic criterion should be to indicate datings as accurately as possible. At the time of the data collection, datings that fulfil this prerequisite were taken into consideration (apart from a few exceptions which, indeed, relate to the initial phase of the research).

35 See Appendices II and III. 
a. General information on the codex (shelf mark, catalogue, writing support, size).

b. Information useful for locating the volume in time and space (dating, place of production, scribe).

c. Information regarding the text and language (text typology, principal author, principal text, language of the text, prose or verse form).

d. Material characteristics (number of leaves, dimensions of the leaf and written area, layout type, number of lines, quiring, catchwords, quire signatures, ruling technique).

e. Information on the type of script employed and on decorations (presence of initials, illustrations, framing etc.).

f. The codex's 'life history' (patron, client, first owner).

g. Observations.

The definitive corpus of the catalogues to be employed is therefore composed of the elements that best match the parameters summarised above. As we have previously stressed, ${ }^{36}$ included among the criteria that guided the choices we made was a balanced representation of all the countries taken into consideration, a variety of manuscript typologies, and a good representation of the entire period examined-i.e. from the middle of the $12^{\text {th }}$ century up to and including the entire $15^{\text {th }}$ century.

Given that we obviously could not demand that each individual catalogue should conform to all the requirements, an effort was made to ensure that the sample as a whole met them. ${ }^{37}$

Once the corpus to be examined has been identified and the survey data form transferred into a database, ${ }^{38}$ one might reasonably expect that the next step-the acquisition of data-would be an essentially mechanical process, in that it consists in simply applying, with due diligence, the observation protocol. In reality, though, the process of extrapolating data from catalogues is subject to limitations arising from the initial premise, namely the decision to utilise second-hand information that originates from very different sources and was obtained using a different set of criteria and collection methods.

36 Busonero 1995, 14-15.

37 See Appendix I.

38 The survey form was computerised using the Dbase IV program to create a database. Once they had been collected, the data were transferred on to a spreadsheet using Excel 5.0 software. Further data processing was carried out using the same software. 


\subsection{Variables}

The difficulties that one may encounter are roughly speaking three:

- Variables that are very seldom encountered (e.g. the leaf format-in folio, in quarto, etc.-or ruling).

- Variables identified though uneven descriptive criteria (e.g. script type, decoration, catchwords, quire signatures).

- Non-systematically surveyed variables within one and the same catalogue (e.g. catchwords, quire signatures, ruling).

This classification is intended only for illustrative purposes, given that the various issues frequently appear interspersed among each other.

In order to clarify what has been said above, we can briefly focus on the description of ruling as a concrete example. In some catalogues, this parameter is entirely absent, ${ }^{39}$ whilst in others, even if it is mentioned, it is not always specified, in cases where two different techniques are indicated, which technique refers to the horizontal ruling, and which to the vertical justification. In Ker's four catalogues, which without doubt figure among the most important sources of information for this research, the ruling technique is regularly indicated only for the period when the shift from 'blind ruling' to 'colour ruling' occurs. Catchwords and quire signatures are also only referred to by Ker in certain cases: catchwords only get mentioned in the period when they were introduced, which occurred roughly between 1100 and 1150. From then on, according to the scholar, their use became so generalised that their possible absence can be attributed to a mechanical blunder, such as excessive trimming..$^{40}$

Quire signatures are recorded by Ker mainly for the period spanning the mid-12 $12^{\text {th }}$ up to the $14^{\text {th }}$ century. It is obvious that in both this and the previous case (i.e. catchwords) the choices made by the author were determined by unquestionably valid historical and palaeographical considerations, but unfortunately they are not applicable (or at least not usable) in a systematic study of the phenomena based on statistical methods that call for comparable information which is consistently and 'aseptically' surveyed-i.e. without making an a priori selection.

By and large, neither catchwords nor signatures are included among the data present in catalogues. When they are indicated, this is done in several ways:

39 For example, ruling does not appear in Mynors, Balliol, and in Thurn, Würzburg II-1-2, whilst in Kuttner I and II it is not indicated in a systematic way.

40 See Ker I, IX-X. 
these range from a simple mention of their existence-in Mynors, Balliol, one sees the terms 'catchwords and signatures'-to more accurate descriptions, such as those which appear in the M.C.L.P.D.F., where not only the presence but also the absence of such parameters is noted. In order to be able to study the phenomena and their development by applying the appropriate distinctions-both synchronically and diachronically-it would be necessary to know, in the case of catchwords, at least their position in the margin, ${ }^{41}$ whilst for signatures their type would have to be specified (quire signatures, quire and leaf signatures, and so on). ${ }^{42}$

The approach to illumination-which will be taken up again later on in the data analysis section-merits its own discussion: in fact, the decorative apparatus of a codex, whenever it is endowed with one, is described in practically all catalogues. Unfortunately, though, it is not easy to obtain readily comparable data from such descriptions, because not only is the lexicon not unambiguous, but it is also possible that one and the same definition-for example, 'illuminated initial', often employed in concise descriptions-can refer to two very different situations. ${ }^{43}$ Better characterised typologies, too, such as historiated initials, can be referred to in different ways, but even where descriptions are very precise, it is still difficult to establish, beforehand, valid criteria to group them into typologies. In fact, depending on what one wishes to learn from decorationssuch as, for example, an assessment of the greater or lesser quality of a codexit is advisable to define case-by-case comparison parameters, whose application would obviously necessitate a hands-on examination of the sample under consideration. ${ }^{44}$ In the present research, given that we had to deal with a very wide range of situations-which cannot, moreover, be confronted directly-it became necessary, as can be seen by looking at the observations protocol, to create drastically simplified groups, both with respect to initials ${ }^{45}$ and to the other parameters relating to the decorative apparatus, so as to avoid losing information (in the acquisition phase, at any rate).

41 See Kuttner I and II.

42 Sufficiently precise descriptions of signatures can be found in: Frioli, Aldersbach; M.C.L.B.P.F.; Leonardi, Vaticani; Wilmart, Vaticani.

43 For a definition of the term 'ornamental initial', see Maniaci $1996\left(1998^{2}\right), 320$. One finds this term used in a generic way for initials executed with differing degrees of graphic complexity, and sometimes for those which can be given a more specific definition.

44 This is also the case when one wishes to use more detailed records of ornamental initials, but ones which have already been codified-see Maniaci $1996\left(1998^{2}\right), 317-322$. A direct examination of the codex is necessary, in any event.

45 Rubricated, pen-flourished, illuminated and historiated initials. 


\subsection{Data analysis}

The fundamental condition that any kind of quantitative analysis requires, namely to be based on data that are uniform and which can readily be compared, makes it necessary to homogenise information (so that it 'fits' into the fields on the survey form) when the data prove not to be immediately usable in the form in which they are provided in catalogues.

In other words, there are a several variables, such as the size of leaves and of the written area which, when they appear, are readily usable in the form in which they present, ${ }^{46}$ whilst others, such as those discussed above, have to undergo a simplification process.

As an example, we can again use the subject of ruling: the captions 'leadpoint', 'pencil lead', 'graphite' or 'pencil' are all included under the all-encompassing entry lead.

Once the collection of the relevant material has been completed, at the point where one moves on to the next phase of data analysis, which is to say the discovery of the relationships that link the individual variables to one another, and in particular to quiring, it is necessary to make a further effort to rationalise the data in order to render them comparable and therefore analysable.

For our research, then, the main expedients adopted were as follows:

a. Datings, straddling two centuries, were always placed in the last quarter of the earlier of the two. ${ }^{47}$ This was chiefly done to avoid introducing excessive deviations in the overall sample, with respect to the $12^{\text {th }}$ century. For the $13^{\text {th }}$ and $14^{\text {th }}$ centuries the problem does not arise, since, as we shall see, the last decades of the former and early part of the latter are frequently comparable in terms of quantity and modes of production. Needless to say, when the earlier century is chosen, one runs the risk of ante-dating certain manu-

46 Mynors', Balliol, measurements in inches have (obviously) been converted to millimetres. 47 In the case of codices straddling the two centuries, four possible strategies can be adopted: The exclusion of this type of manuscript. In this way one can eliminate at source any possibility of committing an error, although a large number of volumes would be overlooked. Choosing by coin toss the century to date the manuscript to. From the statistical point of view, this is the ideal solution, since it guarantees a success rate of 50\%, and above all eliminates the possibility of systematic distortions occurring. The inclusion of the manuscripts in the sample twice (for each century). Needless to say, this solution would create problems when processing the data, chiefly when surveying each century, since the same manuscript will always appear twice. Choosing, consistently, one of the two centuries. This was the solution settled on: in fact, it results in the same probability of success as the second option (i.e. 50\%). See Bozzolo / Ornato $1980,234-235$. 
scripts, and potentially, as a consequence, some of the phenomena, but this does not invalidate the results obtained. ${ }^{48}$

b. The geographic areas considered in the present research are: England, France, Italy, Germany and the Low Countries. In effect, we also inserted codices produced in other countries, but which in any event can be included in same area of origin so as not to create an excessively fragmented corpus and to always generate sub-groups of a certain size.

The countries were grouped together in the following way:

$\mathrm{e}=$ England, Wales and Scotland

$\mathrm{f}=$ France

$\mathrm{i}=$ Italy

pb (Paesi Bassi, i.e the Low Countries) = Belgium (broadly speaking, i.e.

without distinguishing between Flanders and Wallonia), Flanders,

Holland and Wallonia

pg $=($ Paesi germanici, i.e. Germanic countries $)=$ Austria, Bohemia, Moravia, Germany, Slovakia, Switzerland. ${ }^{49}$

c. The textual typology was limited to the few classes listed in the surveying protocol. Some choices were made at the outset, such as including among the theological manuscripts only university scholastic works, since these are very well characterised from both textual and codicological standpoints in the strict sense-e.g. parchment, size, mise en texte, mise en page-or by placing a work such as the Legenda aurea within the sacred literature category rather than within theology lato sensu, for the reasons stated above. Thus, all the works, and hence all the codices, which could not be defined as scholastic, were listed among the sacred literature.

d. An effort was made to standardise the given name and surname of the author/authors by recording them, wherever possible, in their Latin form (e.g. Torquemada becomes Turrecremada, and so on).

e. With respect to quiring, in cases where there was no predominant quire type-i.e. half the volume plus one element-the decision was made to consider the most represented type of quire the predominant one. This was done because at the data analysis stage it is in any event useful to have a

48 See Bozzolo / Ornato 1980, 235. However, it should be borne in mind that the break between the two centuries is artificial, and furthermore that the manuscripts produced in the early years of the century would broadly speaking exhibit the same codicological characteristics and manufacturing techniques of the previous century.

49 Throughout the contribution, we shall adopt the terms 'German area' and 'Germany' when referring to the relevant geographical area. 
benchmark that represents the favoured type of quire, even if it is not in the majority. In the case of codices presenting with large and irregular quires (generally those made from paper), the decision was made to indicate them as -1 .

f. Concerning the script, a sort of merging strategy was adopted which could potentially raise serious doubts. However, this approach did not remotely presume to represent a script classification model; rather, it was merely intended as a way of rendering the collected data comparable by starting out from a few assumptions. It seemed appropriate to unite within a single group-generically named textualis-all the varieties of 'slow' testuales (textualis posata) encountered (that appear in the catalogues in various wordings), with the exception of rotunda. On the other hand, the group named textualis corsiva includes all the scripts that share a cursive ductus, apart from mercantesca, which is considered separately. The humanist scripts are collected into two large categories, namely umanistica rotunda and umanistica corsiva.

Accordingly, the following categories were adopted:

$\mathrm{t}=$ textualis, which includes: Gothic, gotica libraria, French Gothic, Italian Gothic, Parisiensis.

rot $=$ rotunda, which includes Bononiensis, ${ }^{50}$ textualis rotunda.

tc $\quad=$ textualis corsiva, which includes anglican $a,{ }^{51}$ bastarda, business hands, chancery hand, cursive, library cursive, textualis cursiva, secretary hands. ${ }^{52}$

$\mathrm{umr}=$ umanistica rotunda, which includes antiqua, proto-humanistic script, humanistic, umanistica libraria

umc $=$ humanistic cursive.

mer $=$ mercantesca.

50 Concerning the possibility (or impossibility) of characterising the littera Bononiensis in the context of the rotunda, see Tomiello 1992-1993, passim.

51 Concerning the definition of anglicana, see Ker I, XI. This cursive script originated in the $12^{\text {th }}$ century as 'the ordinary hand of correspondence' and does not exhibit, at least initially, any characteristic which could justify calling it 'English'. However, with the passage of time it became more uniform and developed some peculiar characteristics. In the $14^{\text {th }}$ and $15^{\text {th }}$ centuries, in its model forms, it was adopted in place of Gothic script to lay down texts in codices: it is precisely this form, the so-called non-current anglicana', that Ker refers to using the generic term anglicana. To learn more about the history of this kind of script, see Parkes $1979^{2}$.

52 Business hands and secretary hands are definitions that appear in Ker's catalogues I-IV. 
Before examining the results obtained, it should be made clear that not all the information collected has been used in the present research, and that not all the analysed data will be taken into account. ${ }^{53}$

Harvested but unused information includes specifics on the origin of the manuscript-in fact, in addition to its country of origin, details concerning its geographical zone (e.g. northern, southern, etc.), region of origin, city and associated institution are sought-as well as data relating to its history, which is to say details on the scribe, patron, client, owner, etc. Such data were not directly used in the current phase of the research, but could serve as a useful foundation in the future to develop and conduct a closer and more in-depth investigation, once an overall picture has been drawn.

Catchwords are an example of a feature which has been analysed, but will not be discussed in this contribution. In fact, merely their presence or absence was noted; any statistic that locates them within a margin would not be significant, since there are too few cases in which their position is explicitly specified. Thus, such a generic parameter was not considered particularly relevant in relation to quiring.

In the case of quire signatures, too, we were unable to make any comparisons because the collected data proved to be too patchy and lacking in uniformity.

Concerning the script, notwithstanding the groups created, it was not possible to identify any sufficiently clear trends, because in spite of the large number of manuscripts considered, this parameter is only furnished in a few catalogues, and therefore the number of instances surveyed was not sufficient to identify meaningful divisions that were not due to structural effects. ${ }^{54}$ Additionally, one should always bear in mind that the script can depend on the type of text, which in turnas we shall see-seems to be more directly correlated to quiring than to the writing itself.

Decoration, too, does not appear to be a parameter that can immediately be correlated to quiring, in that it seems to be (and in fact is) linked, above all, to the type of text. Practically speaking, in order to ascertain whether or not links exist between quiring and the decorative apparatus, it would be necessary to isolate all the other variables which could potentially-or explicitly-interact with quiring, so as to be able to demonstrate the extent to which the two parameters exert a

53 Data which do not reveal sufficiently significant trends are not closely analysed.

54 The differences observed could stem from the composition of the sample in its subdivisions. For example, in the $15^{\text {th }}$ century quinions made from paper and quinions made from parchment written in Humanistic script. 
direct reciprocal influence. This is a task that would cause us to stray too far from our stated objective.

\section{The evolution of quiring}

\subsection{The corpus}

The corpus of manuscripts upon which our investigation is based is composed of some 3,410 individual codicological units. Specifically, the items representing each century number as follows:

$$
\begin{aligned}
& -12^{\text {th }} \text { century }=386 \text { manuscripts } \\
& -\quad 13^{\text {th }} \text { century }=637 \text { manuscripts } \\
& -\quad 14^{\text {th }} \text { century }=620 \text { manuscripts } \\
& -\quad 15^{\text {th }} \text { century }=1,767 \text { manuscripts }
\end{aligned}
$$

It should be borne in mind that in these total numbers are included a number of codices-albeit very few-dated to within a century, rather than to within half a century. ${ }^{55}$ It can therefore happen that in the analysis phase when, for example, the items from the $15^{\text {th }} .1$ and $15^{\text {th }} .2$ centuries are added together, a total of 1,767 is not reached, but instead a slightly lower number.

It can also happen that for a given century a number of units lower than the one listed above can appear. This may occur in instances where only certain variables are considered rather than all of them-for example, codices formed exclusively from quaternions, quinions or senions, excluding the presence of other types of quire.

\subsection{The overall diachronic picture}

The picture that emerges from the analysis of the collected data relating to the $12^{\text {th }}$ century largely confirms what we had expected, namely that this period, despite being replete with cultural turmoil and harbingers of great changes in relation to the institutional oversight of cultural activities, did not produce any particularly noteworthy innovations with respect to the material structure of the codex. The predominance of the quaternion over other types of quire is over-

55 See what has previously been stated regarding the variables. 
whelming (see Chart 1), even if a small presence of quinions appears, representing $3 \%$ of the total sample.

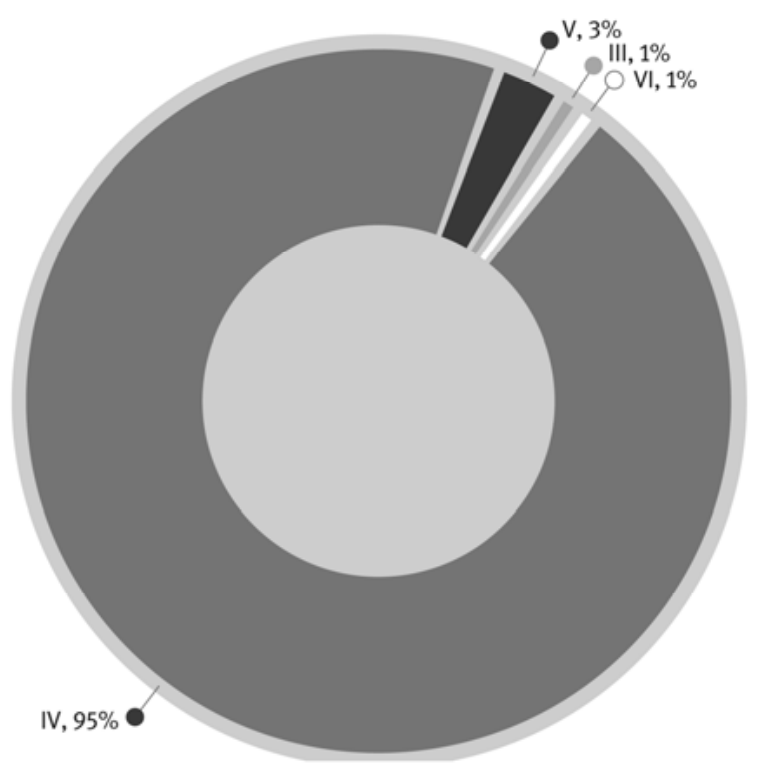

Chart 1: Quiring distribution in the $12^{\text {th }}$ century

By contrast, the $13^{\text {th }}$ century introduces a clear change in the choices that guide the manufacture of the codex. The situation appears very different in comparison to the previous century: indeed, one is struck by both the clear decline in the use of the quaternion, which falls from $95 \%$ to less than $40 \%$, and the appearance of new types of quire (see Chart 2). One notes, in particular, a strong presence of senions-whose usage rate proves to be greater than that of quaternions-together with a certain quota of quinions, representing $10 \%$ of the total sample. The remainder of the output centres on other types of quire, among which particularly thick ones stand out (these are formed from eight, ten or twelve bifolia). 


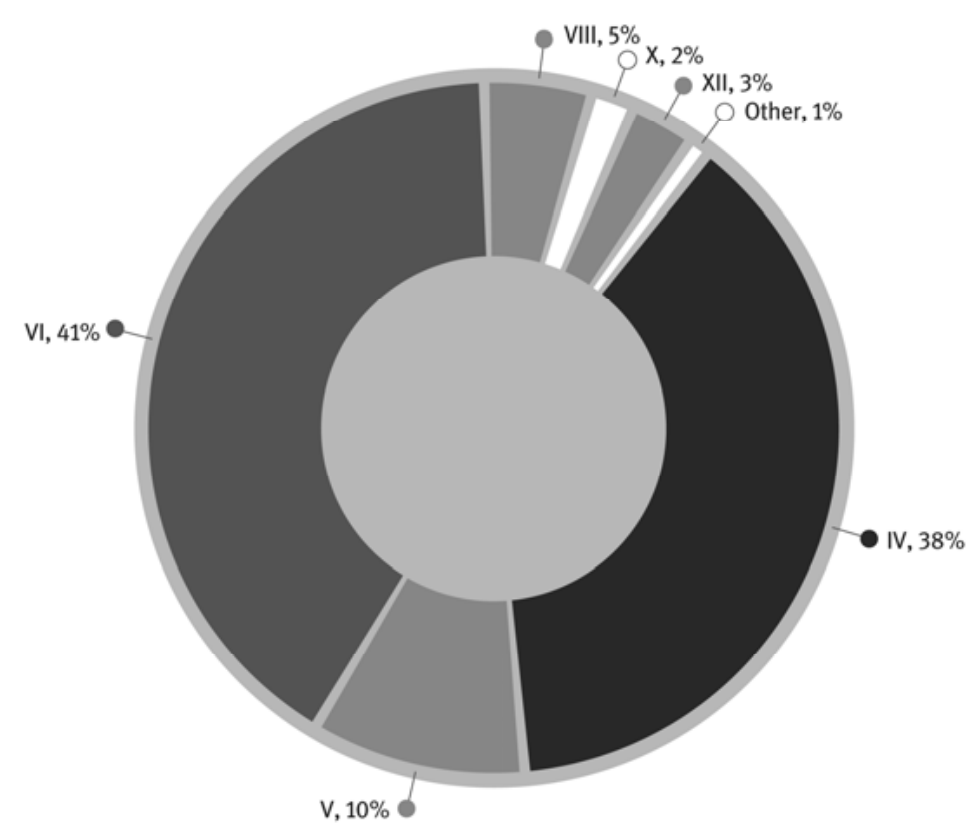

Chart 2: Quiring distribution in the $13^{\text {th }}$ century

Clearly, we find ourselves in the presence of a sort of 'revolution' in the techniques used to manufacture codices: in fact, one passes from an absolute predominance-in the $12^{\text {th }}$ century-of the quaternion, to a clear propensity in favour of the senion, a type of quire which, based on testimony dating from antiquity onwards, had not been used up until then, if not in a rather sporadic way.

In the $14^{\text {th }}$ century, the diffusion of quaternions and senions appears to be almost unchanged with respect to the $13^{\text {th }}$ century. In fact, the distribution of the two types of quire within the sample represents about $40 \%$ of the total production (see Chart 3). Therefore, a situation where the use of each type of quire is equal emerges. However, a strong increase in the use of quinions should be noted; this proves to be almost double that seen in the preceding century. A closer analysis of this period, carried out by creating subdivisions in centuries and regions, will allow us to better illustrate the phenomenon in due course. 


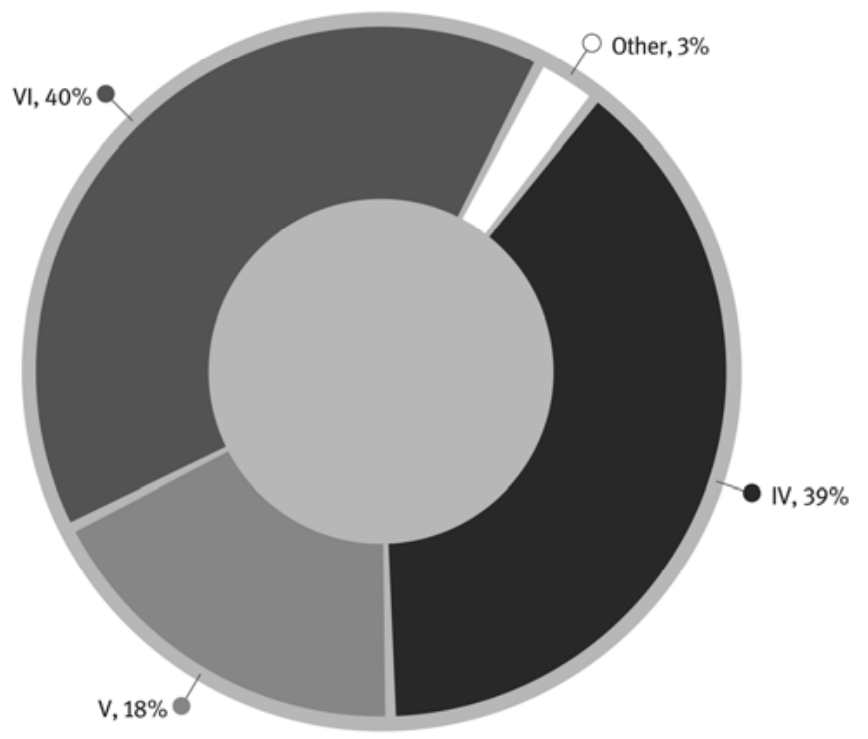

Chart 3: Quiring distribution un the $14^{\text {th }}$ century

From an examination of the data relating to the $15^{\text {th }}$ century (see Chart 4), the following characteristics emerge quite clearly:

a. The level of diffusion of quaternions is the same as that seen in the preceding century.

b. Quinions show an ever-increasing rate of production, so much so that it moves from $18 \%$ in the $14^{\text {th }}$ century to some $31 \%$ in the $15^{\text {th }}$.

c. Senions show a visible decline, decreasing to a level of $26 \%$.

d. One notes a minimal presence of other types of quire, among which stand out octonions, which account for $2 \%$ of the output. 


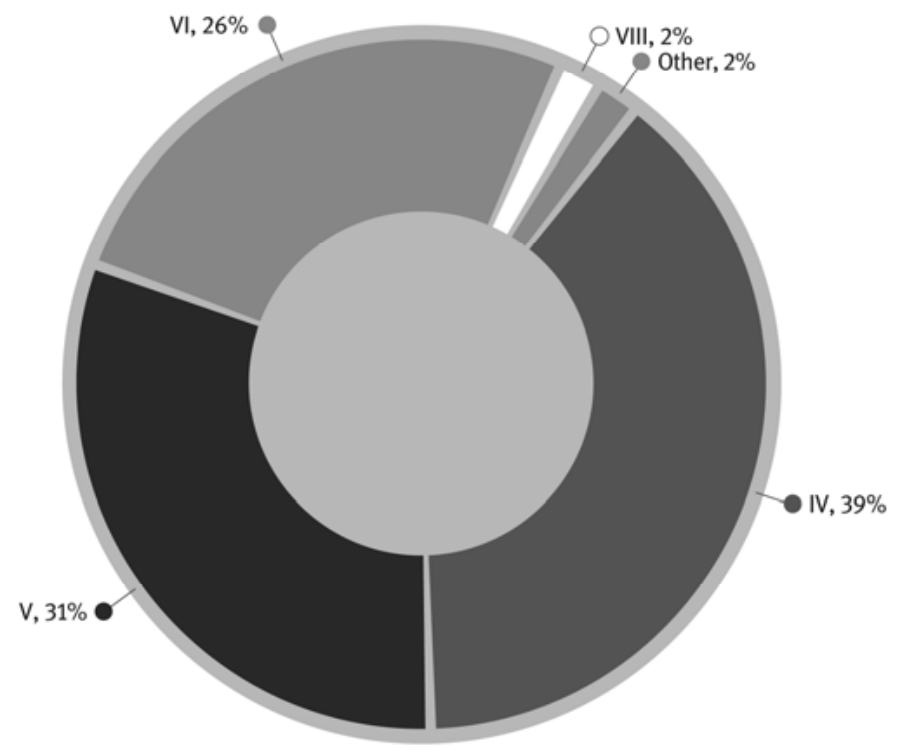

Chart 4: Quiring distribution in the $15^{\text {th }}$ century

Needless to say, with respect to the $15^{\text {th }}$ century-and to a certain extent also the $14^{\text {th }}$-one should not speak of manuscript production in general without distinguishing between parchment and paper. ${ }^{56}$ However, we have decided to dedicate a separate discussion to the writing support and its influence on quiring, when addressing the parameters that are more clearly correlated to quiring.

At this point, then, we have at our disposal a picture of the diachronic development of quiring based on an initial perusal of the data. It is a very broad picture, since it represents several centuries and encompasses the entire output of the countries included in the research. In fact, in order to verify where, when, and possibly why specific phenomena occurred, it is necessary to carry out a more detailed analysis of our corpus. This entails an examination of each country by subdividing production into shorter time spans, namely fifty-year intervals.

56 Along with parchment and paper manuscripts, we must also consider 'mixed' ones-i.e. manuscripts composed of paper quires in which either the external or internal bifolium (or both) are made from parchment-and those made using partly parchment and partly paper quires. 


\subsection{Country-by-country specific pictures}

\subsubsection{England}

In the $12^{\text {th }}$ century, manuscripts in England were mostly structured in quaternions, even if it should be pointed out that quinions were also used to a certain extent-in fact, quinions are present in about $9 \%$ of the total number of manuscripts-whilst only two codices are structured in senions. In effect, the portion of codices made using quires other than quaternions is extremely low, but in any event consistent with the numbers recorded in the other countries examined (see the column that relates to England in Tab. 1).

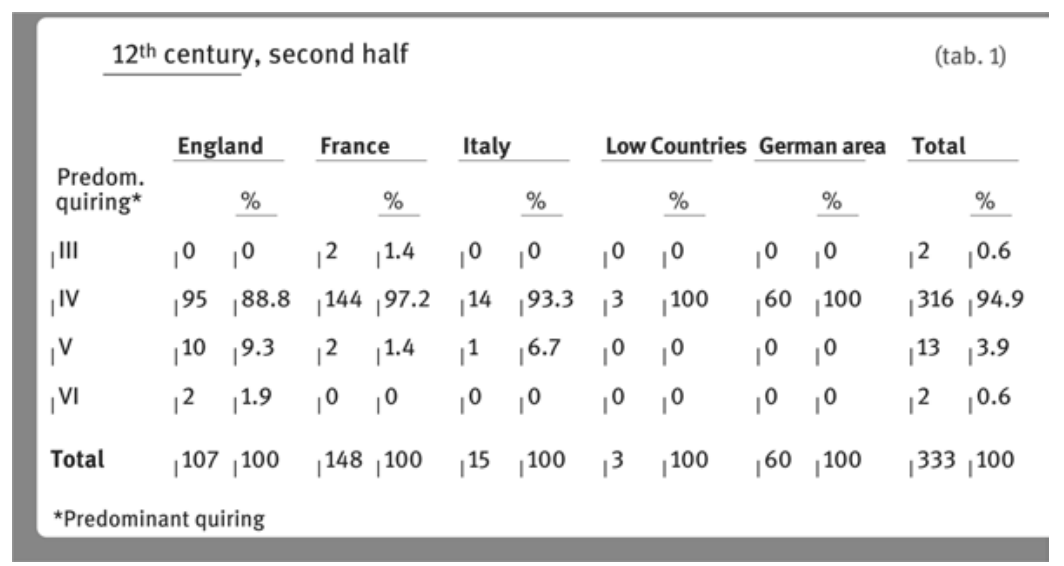

Tab. 1: Quiring $12^{\text {th }}$ century, second half

In the first part of the $13^{\text {th }}$ century a shift is already beginning to be seen: quaternions are still predominant, in that they represent well over half of the total number of items (56.7\%), but quinions and senions start to become a significant alternative, to the extent that they appear at a rate in excess of $20 \%$.

On the other hand, production in the second half of the century is entirely orientated in favour of senions, which reach a $64 \%$ level of diffusion. The rate at which quaternions are used descends sharply to $14 \%$, but quinions also register a considerable contraction and represent only $8.2 \%$ of the total number of units.

In the meantime-as revealed through the analysis of data relating to the $13^{\text {th }}$ century-new types of quire composed of ten and twelve bifolia start to appear (see Tab. 2). 


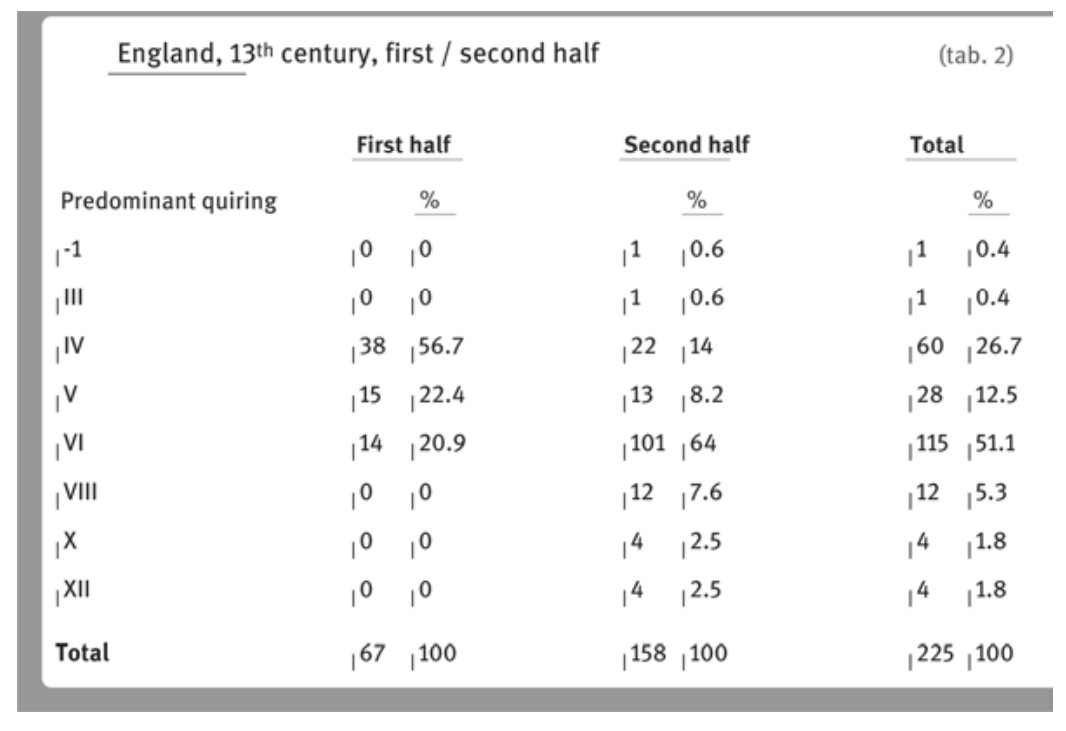

Tab. 2: Quiring England, $13^{\text {th }}$ century, first / second half

It is plain to see, then, that already in the first half of the century a certain tendency to employ thicker quire types is observed, but this choice seems to involve in equal measure both quinions and senions. Later on, however, senions become the indisputable quire of choice, not only in relation to the quaternion but also with respect to the quinion.

In the first half of the $14^{\text {th }}$ century one can immediately see some differences in comparison to the preceding fifty-year period: the senion still represents the prevailing quire type, accounting for almost $60 \%$ of the total output, but at the same time a clear revival of the quaternion emerges-indeed, its diffusion triples to about $36 \%$-whilst there is a further reduction in the use of the quinion.

Conversely, in the second half of the century, a complete inversion of the trend is observed: the quaternion once again becomes the quire of choice, so much so that it accounts for $56.5 \%$ of production, whilst the senion declines by some 23 points, clearly to the advantage of the quaternion, given that the rate of the quinion's diffusion shows no change, and that the other types of quire certainly do not achieve levels worthy of note (see Tab. 3). 
England, $14^{\text {th }}$ century, first / second half

(tab. 3)

\begin{tabular}{|c|c|c|c|c|c|c|}
\hline \multirow[b]{2}{*}{ Predominant quiring } & \multicolumn{2}{|c|}{ First half } & \multicolumn{2}{|c|}{ Second half } & \multicolumn{2}{|c|}{ Total } \\
\hline & & $\%$ & & $\%$ & & $\%$ \\
\hline $1^{-1}$ & $\left.\right|^{1}$ & 1.5 & $1^{2}$ & |1.3 & $1^{3}$ & | 1.4 \\
\hline |'I' & 10 & 10 & $1^{2}$ & |1.3 & $1^{2}$ & 0.9 \\
\hline IV & $1^{24}$ & |36.4 & 87 & ,56.5 & |111 & |50.4 \\
\hline , V & $1^{2}$ & $1^{3}$ & $1^{6}$ & |3.9 & 8 & |3.6 \\
\hline |VI & 139 & ן 59.1 & ,56 & | 36.4 & 95 & | 43.2 \\
\hline |VIII & 10 & $1^{0}$ & $\left.\right|^{1}$ & |0.6 & $\left.\right|^{1}$ & 0.5 \\
\hline Total & ,66 & 100 & 15 & 100 & 220 & 100 \\
\hline
\end{tabular}

Tab. 3: Quiring England, $14^{\text {th }}$ century, first / second half

England, $15^{\text {th }}$ century, first / second half

(tab. 4)

\begin{tabular}{|c|c|c|c|}
\hline & First half & Second half & Total \\
\hline Predominant quiring & $\%$ & $\%$ & $\%$ \\
\hline-1 & $1^{0} \quad ।^{0}$ & $1^{2} \quad ।^{0.9}$ & $1^{2} \quad ।^{0.5}$ \\
\hline |III & $\left.\right|^{1} \quad ।^{0.7}$ & $\perp^{0} \quad ।^{0}$ & $\left.\left.\right|^{1} \quad\right|^{0.3}$ \\
\hline IV & 113, 74.8 & | $151,69.9$ & | 264.9 \\
\hline V & $\left.1^{4} \quad\right|^{2.6}$ & $\left.\right|^{10}, 4.6$ & $\left.\left.\right|^{14} \quad\right|^{3.8}$ \\
\hline $\mathrm{VI}$ & | $28 \quad$ 18.6 & |35 , 16.2 & |63 17.2 \\
\hline VII & $1^{0} \quad ।^{0}$ & $1^{4} \quad ।^{1.9}$ & $।^{4} \quad ।^{1.1}$ \\
\hline VIIII & $1^{3} \quad 1^{2}$ & $\left.\left.\right|^{8} \quad\right|^{3.7}$ & $\left.\left.\right|^{11} \quad\right|^{3}$ \\
\hline$x$ & $1^{0} \quad ।^{0}$ & $\left.\left.\right|^{3} \quad\right|^{1.4}$ & $\left.\left.\right|^{3} \quad\right|^{0.8}$ \\
\hline XII & $\left.\left.\right|^{2} \quad\right|^{1.3}$ & $\left.\left.\right|^{3} \quad\right|^{1.4}$ & $\left.\left.\right|^{5} \quad\right|^{1.4}$ \\
\hline otal & |151, 100 & |216 100 & 100 167, \\
\hline
\end{tabular}

Tab. 4: Quiring England, $15^{\text {th }}$ century, first / second half

The first part of the $15^{\text {th }}$ century shows a marked preference for the quaternion, which presents a rate of diffusion equivalent to almost three quarters of the total production. The balance of the sample is composed of senions, which appear at a rate of $18.6 \%$, and other types of quire, including quinions and 
octonions. In the second half of the century the range of choices that prevails in the manufacture of codices remains, largely speaking, almost unchanged: one observes a decline in both quaternions and senions, and a slight increase in quinions, whilst other types of quire composed of more than six bifolia reappear in a more substantial way (see Tab. 4).

\subsubsection{France}

Twelfth-century France shows a clear preference for the quaternion, which accounts for over $97 \%$ of the total production, accompanied by a small percentage of ternions and quinions (see the column that relates to France in Tab. 1).

In the first half of the $12^{\text {th }}$ century the quaternion is still the predominant quire of choice, accounting for more than three quarters of the total production, even if the senion begins to appear in a significant way-above all in relation to its total absence in the previous century-accounting for more than $15 \%$ of the total. The minimal presence of quinions and octonions should be noted.

During the second half of the century in France one also sees, albeit to a lesser extent, a decisive establishment of the senion, which achieves a rate of dissemination in excess of $38 \%$. In France, the phenomenon is certainly less pronounced than in England during the same period, but in any event one cannot fail to notice a rather marked preference for this type of quire. The rate of production of codices structured in quaternions falls to $31.6 \%$, whereas very substantial quires composed of eight, ten, or twelve bifolia appear, whose presence has already been pointed out when we sketched an overall picture of the $13^{\text {th }}$ century (see Tab. 5 and Chart 2). 
France, $13^{\text {th }}$ century, first / second half

(tab. 5)

\begin{tabular}{|c|c|c|c|c|c|}
\hline \multirow{3}{*}{$\begin{array}{l}\text { Predominant quiring } \\
\text { IV }\end{array}$} & \multicolumn{2}{|c|}{ First half } & Second half & \multicolumn{2}{|c|}{ Total } \\
\hline & & $\%$ & $\%$ & & $\%$ \\
\hline & $1^{44}$ & |75.9 & $1^{49}, 31.6$ & 93 & 143.7 \\
\hline ।V & $1^{2}$ & 3.4 & $\left.\left.\right|^{9} \quad\right|^{5.8}$ & $\left.\right|^{11}$ & $1^{5.1}$ \\
\hline , $\mathrm{VI}$ & $1^{9}$ & 15.5 & |60 38.7 & 169 & |32.4 \\
\hline |VIII & $1^{2}$ & 3.5 & 14 & |16 & 1.5 \\
\hline${ }_{1}^{x}$ & $\left.\right|^{1}$ & $\left.\right|^{1.7}$ & $\left.\left.\right|^{6} \quad\right|^{3.9}$ & $1^{7}$ & 1.3 \\
\hline${ }_{1} \mathrm{XI}$ & $1^{0}$ & $1^{0}$ & $\left.\left.\right|^{1} \quad\right|^{0.7}$ & $\left.\right|^{1}$ & 0.5 \\
\hline |XII & $1^{2}$ & $1^{0}$ & $\left.\left.\right|^{16}\right|^{10.3}$ & 16 & I.5 \\
\hline Total & $1^{58}$ & |100 & 100 155 & $\left.\right|^{213}$ & 100 \\
\hline
\end{tabular}

Tab. 5: Quiring France, $13^{\text {th }}$ century, first / second half

France, $14^{\text {th }}$ century, first / second half

\begin{tabular}{|c|c|c|c|c|c|c|}
\hline \multirow[b]{2}{*}{ Predominant quiring } & \multicolumn{2}{|c|}{ First half } & \multicolumn{2}{|c|}{ Second half } & \multicolumn{2}{|c|}{ Total } \\
\hline & & $\%$ & & $\%$ & & $\%$ \\
\hline ,IV & |10 & |26.3 & $\left.\right|^{41}$ & |54.7 & $\left.\right|^{51}$ & | 45.1 \\
\hline ।V & & |13.2 & $1^{3}$ & $1^{4}$ & | 8 & $\left.\right|^{7.1}$ \\
\hline , $\mathrm{VI}$ & $1^{23}$ & 160.5 & $1^{30}$ & $1^{40}$ & $1^{53}$ & | 46.9 \\
\hline |XII & $1^{0}$ & $1^{0}$ & $\left.\right|^{1}$ & |1.3 & |1 & | 0.9 \\
\hline Total & $\left.\right|^{38}$ & 100 & $\left.\right|^{75}$ & 100 & 113 & 100 \\
\hline
\end{tabular}

Tab. 6: Quiring France, $14^{\text {th }}$ century, first / second half

The first half of the $14^{\text {th }}$ century sees a reversion to the predominant choice of the senion for the manufacture of codices. Indeed, the senion becomes the most commonly used quire, appearing in more than $60 \%$ of the total production. The number of quaternions shows a further decline-of about 5 percentage points-in comparison to the preceding period, whilst the number of quinions reaches $13.2 \%$. Compared with the second half of the $13^{\text {th }}$ century, one 
sees the disappearance of quires made from eight or more bifolia, which overall accounted for almost a quarter of the total French production (23.9\%), and well over a tenth of English (12.6\%), where, indeed, one observes the same phenomenon (see Tab. 6; for England Tab. 2 and 3).

In France, too, in the second half of the century one sees an inversion of the trend: the quaternion's presence increases by about 28 percentage points (54.7\%) compared with the preceding half-century, whilst the senion decreases to $40 \%$ of the total production (see Tab. 6).

If one compares this trend with the one seen in England during the same period, it becomes clear that in reality there are no great differences between the two countries: the percentages of codices composed of quaternions, quinions and senions register values that are on the whole comparable in both areas of production (see Tab. 3 and 6).

In the first half of the $15^{\text {th }}$ century, too, we observe a considerable convergence of the choices made in the two countries. In fact, broadly speaking, French manuscript production breaks down into the same figures for quaternions and quinions as those we have identified in the English manuscript, with the former representing $74 \%$ of the total and the latter $20 \%$. There are no quinions in the sample of French manuscripts of this period, whereas we find some quires composed of more than six bifolia-among which octonions in particular.

In the second half of the century the 'balance of power', so to speak, between the various types of quiring remains almost unchanged, apart from the reappearance of a small percentage of quinions and a decline in the number of 'heftier' quires (see Tab. 7). 
France, $15^{\text {th }}$ century, first / second half

(tab. 7)

\begin{tabular}{|c|c|c|c|c|c|}
\hline \multirow[b]{2}{*}{ Predominant quiring } & \multicolumn{2}{|c|}{ First half } & Second half & \multicolumn{2}{|c|}{ Total } \\
\hline & & $\%$ & $\%$ & & $\%$ \\
\hline $1^{-1}$ & $1^{0}$ & 10 & $\left.\left.\right|^{3} \quad\right|^{1.6}$ & $1^{3}$ & |1.1 \\
\hline IV & 52 & $1^{74.3}$ & | 134 70.1 & |186 & | 71.3 \\
\hline ।V & $1^{0}$ & $1^{0}$ & $\left.1^{7} \quad\right|^{3.7}$ & $1^{7}$ & $1^{2.7}$ \\
\hline , $\mathrm{Vl}$ & $\left.\right|^{14}$ & $1^{20}$ & $\left.\left.\right|^{41}\right|^{21.5}$ & $1^{55}$ & $\left.\right|^{21.1}$ \\
\hline ।VII & $\left.\right|^{1}$ & 1.4 & $\left.\left.\right|^{1} \quad\right|^{0.5}$ & $1^{2}$ & $\left.\right|^{0.8}$ \\
\hline ,VIII & $1^{2}$ & $\left.\right|^{2.9}$ & $1^{4} \quad 1^{2.1}$ & $1^{6}$ & $1^{2.3}$ \\
\hline${ }_{1} \mathrm{x}$ & $\left.\right|^{1}$ & 1.4 & $\left.\left.\right|^{1} \quad\right|^{0.5}$ & $1^{2}$ & $1^{0.7}$ \\
\hline Total & 10 & 100 & 1900 191 100 & 261 & 100 \\
\hline
\end{tabular}

Tab. 7: Quiring France, $15^{\text {th }}$ century, first / second half

\subsubsection{Italy}

With respect to Italian production in the $12^{\text {th }}$ century and in the first half of the $13^{\text {th }}$, our sample is extremely limited,,$^{57}$ but a preference for the quaternion seems unquestionable.

In the second half of the $13^{\text {th }}$ century, however, a rather singular picture emerges in which quaternions, quinions and senions are abundantly represented. Or rather, the last-mentioned account for a $41 \%$ rate of production, whilst quaternions account for $34.5 \%$. In fact, one could hypothesise that Italy, too, during the $13^{\text {th }}$ century, was affected-perhaps following an influx from beyond the Alps-by the widespread 'vogue' for senions in England and France. The percentage of quinions, however, should not be underestimated (21.3\%), since they are used far more than in the other European countries (see Tab. 8).

57 In actual fact, Italian manuscript production in the first half of the $13^{\text {th }}$ century is not at all sparse; rather, the number of catalogued codices is low, and among these the number of explicitly localised and dated to the half century is commensurately low. 
Italy, $13^{\text {th }}$ century, second half

(tab. 8)

\begin{tabular}{|c|c|c|}
\hline \multirow[b]{2}{*}{ Predominant quiring } & \multicolumn{2}{|c|}{ Second half } \\
\hline & & $\%$ \\
\hline |'II & $\left.\right|^{1}$ & |1.6 \\
\hline IV & 21 & 34.5 \\
\hline । $v$ & $\left.\right|^{13}$ & $\left.\right|^{21.3}$ \\
\hline , VI & $1^{25}$ & $1^{41}$ \\
\hline ।VII & $\left.\right|^{1}$ & $\left.\right|^{1.6}$ \\
\hline Total & |61 & 100 \\
\hline
\end{tabular}

Tab. 8: Quiring Italy, $13^{\text {th }}$ century, second half

A few comments about the first half of the $14^{\text {th }}$ century, despite the rather small size of the sample, may be of some value. The numbers of codices composed of quaternions, quinions and senions in the sample are roughly equal: ${ }^{58}$ in fact, in comparison to the preceding half-century, one sees a reduction of both the percentage of quaternions and, above all, of senions, whilst at the same time the percentage of codices composed of quinions increases.

In the second half of the $14^{\text {th }}$ century the leading role played by the quinion by now becomes clear, to the extent that it is employed in some $46 \%$ of Italian production, whereas the quaternion is seen in about $29 \%$ of volumes, and the senion's presence declines to $19.4 \%$ of the total. Quires composed of eight or more bifolia also appear, even if their overall percentage is of no great significance (see Tab. 9).

58 In fact, the quaternions' score is about $28 \%$, whilst the senions and quinions each score roughly $33 \%$. 
Italy, $14^{\text {th }}$ century, first / second half

(tab. 9)

\begin{tabular}{|c|c|c|c|c|c|}
\hline \multirow[b]{2}{*}{ Predominant quiring } & \multicolumn{2}{|c|}{ First half } & Second half & \multicolumn{2}{|c|}{ Total } \\
\hline & & $\%$ & $\%$ & & $\%$ \\
\hline ।" & $\left.\right|^{1}$ & $\left.\right|^{2.8}$ & $\left.\left.\right|^{1} \quad\right|^{0.8}$ & $1^{2}$ & $\left.\right|^{1.2}$ \\
\hline ।III & $1^{0}$ & 10 & $\left.\left.\right|^{1} \quad\right|^{0.8}$ & $\left.\right|^{1}$ & । 0.6 \\
\hline , IV & $\left.\right|^{10}$ & |27.8 & $\left.\right|^{37} \quad$ |28.7 & 147 & 28.5 \\
\hline ।V & $\left.\right|^{12}$ & |33.3 & |60, 46.5 & $\mathrm{I}^{72}$ & | 43.7 \\
\hline ।VI & |12 & |33.3 & $\left.\left.\right|^{25} \quad\right|^{19.4}$ & $1^{37}$ & $\left.\right|^{22.4}$ \\
\hline ।VII & $\left.\right|^{1}$ & $\left.\right|^{2.8}$ & $1^{0} \quad 1^{0}$ & $\left.\right|^{1}$ & । 0.6 \\
\hline ।VIII & 10 & 10 & $\left.\left.\right|^{2} \quad\right|^{1.5}$ & $1^{2}$ & $\left.\right|^{1.2}$ \\
\hline ।IX & $1^{0}$ & $1^{0}$ & $\mathbb{L}_{1}^{1} \mid 0.8$ & $\left.\right|^{1}$ & |0.6 \\
\hline${ }_{1}^{x}$ & 0 & $1^{0}$ & $\left.\left.\right|^{2} \quad\right|^{1.5}$ & $1^{2}$ & $\left.\right|^{1.2}$ \\
\hline Total & 36 & 100 & 100 129 & |165 & |100 \\
\hline
\end{tabular}

Tab. 9: Quiring Italy, $14^{\text {th }}$ century, first / second half

Production in the first half of the $15^{\text {th }}$ century is mostly centred on the quinion, which accounts for $64 \%$ of the total. In contrast to England and France, where the quaternion showed a robust resurgence, in Italy we see the quinion fully embraced, where it not only consolidates itself as the technical solution of choice, but even increases its dissemination in the second half of the $15^{\text {th }}$ century, and ultimately reaches a level of $72.2 \%$.

As far as other types of quire are concerned in the first half of the $15^{\text {th }}$ century, quaternions represent $17 \%$ of the total production and senions $15 \%$, whereas in the second half of the century they descend to around $14 \%$ and $9 \%$, respectively. The percentages of the other types of quire-disregarding octonions, which top $2 \%$ in both halves of the century-are virtually irrelevant (see Tab. 10). 


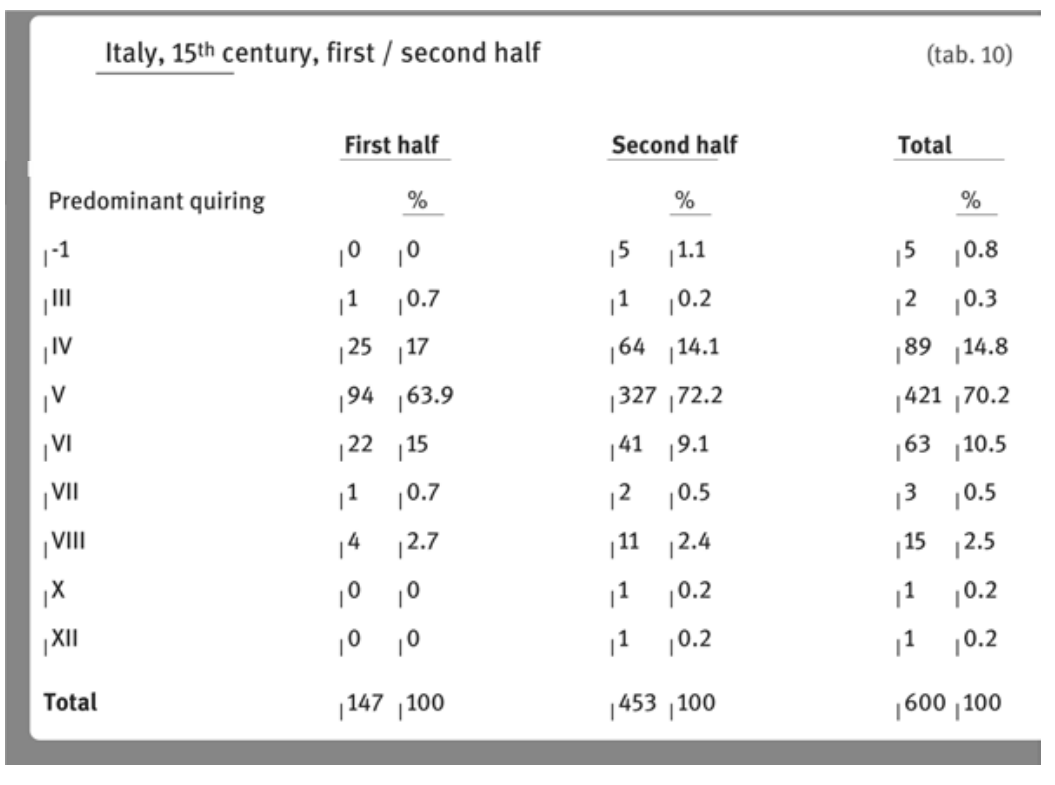

Tab. 10: Quiring Italy, $15^{\text {th }}$ century, first / second half

\subsubsection{Germany}

$12^{\text {th }}$-century Germany seems to be entirely oriented towards the quaternion-at least with respect to the sample at our disposal (see the column that relates to Germany in Tab. 1). For the $13^{\text {th }}$ and $14^{\text {th }}$ centuries we have too few codices at our disposal $^{59}$ to allow us to draw any hard and fast conclusions. A mere glance at the data allows one to see that, in the first half of the $13^{\text {th }}$ century, the quaternion is the most frequently employed quire type, to the extent that it is present in 10 of the 11 attested manuscripts. ${ }^{60}$ In the second half of the century one still sees a predominance of quaternions: in fact, of 14 manuscripts attributed to this period 7 are composed of quaternions, 2 of quinions, 4 of senions, and 1 of octonions.

The available sample of codices for the $14^{\text {th }}$ century is also very limited: for the first half of the century we can only report that 2 of the 5 codices that date from this time span are composed of quaternions, 2 of quinions, and one of octonions,

59 A very small number of manuscripts dating from the $13^{\text {th }}$ and $14^{\text {th }}$ centuries emerged from a perusal of catalogues in the first phase of this research.

60 A twelfth instance is represented by a codex structured in senions. 
whereas for the second half of the century, of the 16 representative codices, 5 are structured in quaternions, 4 in quinions, 6 in senions, and one is composed of thick and irregular quires.

As regards the $15^{\text {th }}$ century, thanks to a rather substantial sample, it is possible to identify some trends with a reasonable degree of accuracy. In fact, Germany presents, for the first half of the century, a totally different situation in comparison to that observed in England and France-where there was a resurgence of the quaternion-and in Italy, where the quinion prevailed. Indeed, one observes an absolute predominance of the senion, which accounts for some $71.2 \%$ of the total production, whereas the quaternion and quinion account for $9.1 \%$ and $15.2 \%$ of the output, respectively. ${ }^{61}$ It should also be pointed out that quires composed of more than six bifolia account for $4.5 \%$ of the total sample. Largely speaking, in the second half of the century the overall picture of the choices made remains unchanged, apart from a small growth in the number of manuscripts structured in quaternions, which increases by about $5 \%$, to reach $14.4 \%$, and a slight decline ( 2 points) in codices composed of quinions (see Tab. 11).

\begin{tabular}{|c|c|c|c|c|}
\hline \multicolumn{4}{|c|}{ German area, $15^{\text {th }}$ century, first / second half } & (tab. 11) \\
\hline & Firs & thalf & Second half & Total \\
\hline Predominant quiring & & $\%$ & $\%$ & $\%$ \\
\hline IV & $1^{6}$ & |9.1 & $\left.\right|^{34}, 14.4$ & $1^{40}, 13.2$ \\
\hline ।V & $\left.\right|^{10}$ & 15.2 & $\left.\right|^{31}, 13.2$ & , 131 13.6 \\
\hline । $\mathrm{VI}$ & $1^{47}$ & 171.2 & । 170 ,72 & | 217 ,71.9 \\
\hline |VIII & $1^{2}$ & $1^{3}$ & $\left.\perp^{0} \quad\right|^{0}$ & $।^{2} \quad ।^{0.7}$ \\
\hline $\mathrm{I}^{\mathrm{IX}}$ & $\left.\right|^{1}$ & 1.5 & $\left.\perp^{0} \quad\right|^{0}$ & $\left.\left.\right|^{1} \quad\right|^{0.3}$ \\
\hline${ }_{1} \mathrm{XII}$ & 10 & $1^{0}$ & $\left.\left.\right|^{1} \quad\right|^{0.4}$ & $।^{1} \quad ।^{0.3}$ \\
\hline Total & , 66 & 100 & |236,100 & |302,100 \\
\hline
\end{tabular}

Tab. 11: Quiring German area, $15^{\text {th }}$ century, first / second half

61 Rhineland production of the $15^{\text {th }}$ century exhibits a quiring distribution pattern which is essentially similar to that described here. See Bozzolo 1994, 232. 


\subsubsection{The Low Countries}

In our corpus, the number of codices produced in the Low Countries reaches a sufficient value only in the $15^{\text {th }}$ century, particularly in its second half. In the first half of the century manuscripts are predominantly composed of quaternions, which account for around $61 \%$ of the total output. A more modest number of codices structured in senions also appears (28.6\%), whilst about a tenth of the output opts for the quinion. In the second part of the century-for which we have a decidedly more representative sample-one meets with an almost identical situation to the one just described. There is a slight increase in the diffusion of quaternions (64.2\%), whilst the quinions and senions lose a some of their ground-2.3 and 6.5 points, respectively. A small number (2.1\%) of codices composed of ternions and octonions is also present (see Tab. 12).

\begin{tabular}{|c|c|c|c|c|c|c|}
\hline \multicolumn{5}{|c|}{ Low Countries, $15^{\text {th }}$ century, first / second half } & \multicolumn{2}{|c|}{ (tab. 12) } \\
\hline & Firs & half & Seco & ond half & Tota & \\
\hline Predominant quiring & & $\%$ & & $\%$ & & $\%$ \\
\hline $1^{-1}$ & $1^{0}$ & $1^{0}$ & $1^{1}$ & 1.1 & $\left.\right|^{1}$ & |0.8 \\
\hline ।III & $1^{0}$ & $1^{0}$ & $1^{2}$ & $\left.\right|^{2.1}$ & $1^{2}$ & 1.6 \\
\hline ,IV & |17 & |60.7 & |61 & |64.2 & 18 & |63.4 \\
\hline ।V & $1^{3}$ & 10.7 & 8 & 8.4 & $\left.\right|^{11}$ & 9 \\
\hline , $\mathrm{VI}$ & $1^{8}$ & |28.6 & $\left.\right|^{21}$ & $\left.\right|^{22.1}$ & $1^{29}$ & |23.6 \\
\hline , VIIII & $\left.\right|^{0}$ & 10 & $1^{2}$ & $\left.\right|^{2.1}$ & $1^{2}$ & |1.6 \\
\hline Total & $\left.\right|^{28}$ & 100 & 95 & 100 & |123 & 100 ן \\
\hline
\end{tabular}

Tab. 12: Quiring Low Countries, $15^{\text {th }}$ century, first / second half

\subsection{Conclusions}

Clearly, it is the $13^{\text {th }}$ century that introduces significant changes to the techniques used for the preparation of quires. The country on the cutting edge of innovation is England, whose production, already in the first half of the century, includes a noteworthy number of codices structured in quires other than quaternions, those being quinions and senions. This tendency to favour thicker quires becomes dominant in the second half of the $13^{\text {th }}$ century, but the preference-as we have already 
stressed-is mostly for the senion, whose rate of dissemination is overwhelming. In French production one initially notices the presence of quires other than quaternions in the first half of the century; it is in the second half of the century, however, that the number of codices composed of senions becomes more substantial and accounts for almost two fifths of the total output. However, a substantial establishment of the senion took place in France in the first half of the $14^{\text {th }}$ century-indeed, based on an examination of this trend, one can reasonably suppose that in adopting the technical innovation of the senion, France lagged behind England by a few decades. In fact, despite still being the quire of choice in English production, senions show a slight decline in the first half of the century, in contrast to an increase in the quaternion, whilst in France the use of the senion reaches its apogee.

In the second half of the $14^{\text {th }}$ century there is a change in the criteria employed for the manufacture of codices, due in all likelihood to changes that occurred in the concept of the book. The quaternion fully regains the upper hand, accounting for well over half of the items included in the sample-even if the percentage of codices composed of senions remains quite significant ${ }^{62}$-just as much in French production as in English which, as we have pointed out, largely speaking share (proportionately) the same percentages of codices composed of the various quire types. In the $15^{\text {th }}$ century the quaternion is the most widely used quire in both French and English codex production (more than 70\%), whilst the percentage of senions accounts for about a fifth of the total output.

By contrast, Italian production follows a distinctive course. Whilst in the second half of the $13^{\text {th }}$ century one observes a rather fluid situation (in that the percentage of codices composed of senions is slightly higher than those composed of quaternions), starting in the first half of the $14^{\text {th }}$ century, one sees a gradual establishment of the quinion, which was already well represented in the previous half century (when it accounted for more than a fifth of the total output), and it progressively consolidates its position. In fact, after a few decades, the quinion shows an increasing level of diffusion, until it accounts for almost three quarters of the total production in the second half of the $15^{\text {th }}$ century. It is therefore reasonable to suppose that the share of quinions in the overall diachronic picture mostly originated from Italy.

With regard to production originating from $13^{\text {th }}$ - and $14^{\text {th }}$-century German area, we are unable to offer anything other than a few basic observations. Quinions and senions only begin to appear in the second half of the $13^{\text {th }}$ century, but owing to the meagreness of the data we have at our disposal, we can only verify a mod-

62 The rate for senions in England is 36.4\%, whereas in France it is 40\%. 
erate predominance of senions during the second half of the $14^{\text {th }}$ century. On the other hand, the scenario seen in the first half of the $15^{\text {th }}$ century is entirely in favour of the senion-which at this point had progressively been abandoned in the other countries and relegated to a secondary role. The senion is in fact employed in the bulk of production, even if there is no lack of codices composed of quaternions and, above all, of quinions. In the second half of the century the overall distribution of quire types remains essentially unchanged, apart from a small increase in codices structured in quaternions.

In the Low Countries in the $15^{\text {th }}$ century production follows the same general pattern as that identified in France and England (in fact, the quaternion is the predominant choice), even if the percentage of codices composed of senions amounts to a little less than one quarter of the total.

At this point, then, we are in a position to provide answers to some of the questions we have posed. As regards the shift from quaternions to senions, we can say where and when it happened, but the reason why this great change in the manufacture of the codex occurred remains a mystery.

With respect to the quinion, the places and ways in which it spread are clear enough, despite the lack of an explanation for what spurred such a decisive orientation towards this type of quire in Italian production, whilst in the rest of Europe other choices were made.

The period when manuscripts composed of senions were at their peak stretches from about 1250 to 1350. The phenomenon first emerged in England and spread rapidly in France, subsequently reaching Italy and Germany. In the German area, the senion, even if it was introduced at a rather late date, would never be abandoned, whereas in Italy quinions began their ascent from the $14^{\text {th }}$ century onwards.

Clearly, a change in a manufacturing solution that led to the rejection of a choice consolidated for centuries, namely the construction of codices in quaternions, was not merely the product of chance; rather, it was undoubtedly determined by specific causes, both economic and cultural, which provided an impetus for change. As regards the phenomenon that interests us here, the period in which the spread of the senion reaches its peak coincides roughly with the maximum growth of the university, therefore the relationship between the senion and the university environment appears to be altogether plausible. Additionally, the link between the Italian quinion and higher culture also seems to be undeniable. ${ }^{63}$ Unfortunately, the university statutes studied up till now-those of the universi-

63 We will revisit the discussion regarding the birth of the senion in England when we address the link that exists between quiring and textual typology. 
ties of Paris and Bologna in particular-have not yielded any information on norms relating to the composition of codices, whereas, in the case of Bologna at least, the regulation of manuscript production through the pecia system is very well documented. In fact, as recent studies on Bolognese writing contracts have shown, ${ }^{64}$ the terms pecia and quaternus were employed to refer to units employed to measure text-the term quaternus in particular is used as a unit of measurement, both in agreements drawn up between scribes and patrons and in tax schedules ${ }^{65}$-but the connection between the said terms and the manufactured object that derives from the copying process, or better to say with its material structure, is unknown. To be sure, a pecia does not correspond exactly to a specific part of a quire (for example, half of one, in the case of a quaternion). Indeed, in manuscripts produced by the system, pecia markings can be found at the halfway point or three quarters of the way through a quire. Therefore, all suppositions about the relationship which might exist between pecia and quinion or between pecia and senion remain purely hypothetical.

With respect to the French area, information about the remuneration of scribes is sparse and difficult to interpret. In many instances, it is impossible to discern a relationship between fees and the number of leaves and/or lines copied. Additionally, when the unit of measurement is a quire, one is often unable to apprehend its thickness. A few attestations of copying fees exist that point to a certain type of quire-quaternions or senions, as the case may be-but they are very limited in number and relate to the end of the $14^{\text {th }}$ century, ${ }^{66}$ and therefore do not help to shed much light on the matter.

In fact, it is likely that the use of a different quire structure-a thicker one-is rooted in the new role that was assigned to it: 'the university book is an entirely different object from the book of the Early Middle Ages. It forms part of a completely new technical, social and economic whole, an expression of an elevated civilisation'. ${ }^{67}$ With these words, Jacques Le Goff introduces the new facies of the late medieval book, which at this point had become a study tool and a vehicle for the transmission of new ideas. The book's format changes and becomes smaller and more manageable. It also becomes 'poorer', with a more restrained decorative apparatus, as in the case of philosophical and theological codices, whilst juridical manuscripts remained rather lavish on account of their wealthier readership.

64 For an examination of the problem relating to Bolognese book production and an up-todate bibliography on the subject, see Devoti 1994, passim.

65 See Devoti 1994, 89.

66 Bozzolo / Ornato 1980, 37-40.

67 Le Goff 1979, 86-90. 
One possible hypothesis that could be put forward to explain the change has to do with a technical factor, namely the capacity to produce thinner parchment, ${ }^{68}$ and a need that might have arisen from the growth in university studies, namely the necessity to enclose a given text within a more compact unit. At the same script density, a quire made up from six bifolia contains a larger amount of content, making it possible to collect a higher number of texts in a lower number of units, and therefore perhaps easier to handle and carry around. ${ }^{69}$ It is also likely that the labour required to assemble a codex would be less costly, since the same number of texts would call for fewer quires if a volume were composed of senions rather than quaternions. It is quite possible that ready-made quires were sold that were composed of a larger number of bifolia as a response to this particular need; a need arose from the spread of many works that became an indispensable "package' for university studies.

Needless to say, these are merely suppositions which could, perhaps, be confirmed only after a first-hand examination of a large number of codices, which would make it possible to evaluate and correlate, wherever possible, the textual and material characteristics of the various pieces of evidence. With respect to the latter, among the most obvious changes observed we can include the starting of a quire with the flesh side of the parchment, a phenomenon which is seen consistently from 1250 onwards-and therefore in concomitance with the appearance of the senion-as well as writing below the first line, which appears to occur contemporaneously with the aforementioned phenomenon. ${ }^{70}$ A direct analysis of the material would also make it possible to focus attention not only on all the variables that we have classed as being potentially correlated to quiring, but also, and in particular, on the thickness of the parchment.

Recent studies have shown how a parameter such as thickness, which at first glance might not seem to be particularly significant in the context of the medieval book, is actually of considerable archaeological interest. Indeed, an investigation carried out on four corpora of manuscripts and documents of very different da-

68 In the $13^{\text {th }}$ century parchment became a lot thinner compared to that seen in the previous century. For information on the evolution of parchment thickness over the centuries, see Bianchi et al. 1993, 152, and Bischoff 1993, 72-77, although in reference to documents of the Papal Chancellery.

69 It has been noted that the university environment not only generated a great demand for texts, but also resulted in a heavy circulation of works both in loco and between one university and another. The figure of a teacher or travelling student is a commonly seen topos.

70 See Palma 1988, passim. 
tings and origins ${ }^{71}$ demonstrated that, by starting out from a knowledge of leaf thickness, it is possible to verify-by processing data using established statistical parameters-the uniformity of both the component bifolia within a quire and of one and the same bifolium internally. Additionally, by analysing such data, it becomes possible to ascertain the different manufacturing techniques employedsuch as the arrangement of quires of similar thickness; the criteria applied for placing bifolia in order in relation to their thickness; skin folding methods used for the making of quires, and so on-which lie at the heart of the objects produced in different places and at different times. ${ }^{72}$

The fact that the thickness of parchment was not an entirely irrelevant parameter for the medieval artisan has been amply demonstrated by Frank Bischoff in various studies, ${ }^{73}$ among which a contribution on a sample of evangelaries dating from the $11^{\text {th }}$ and $12^{\text {th }}$ centuries, where he identifies a clear preference for thicker parchment for the creation of quires destined to host miniatures (illustrations, decorated initials, and so on) so as to prevent colours from bleeding through from one side of a leaf to the other. ${ }^{74}$ Clearly, the structuring of a codex in this way represents the outcome of a specific choice which on the one hand can result in obvious disturbances in the arrangement of the text within the quires (if the structure of the volume is not planned with sufficient foresight), ${ }^{75}$ and on the other, more simply, a modification of the typical structure of the quire, which generally seems to entail positioning thicker bifolia on the outside and thinner ones on the inside. ${ }^{76}$

Needless to say, the points clarified above represent overall trends that are worthy of closer investigation, and which certainly present exceptions: for exam-

71 Fifty-six Italian juridical manuscripts dating from the $14^{\text {th }}$ century; 121 codices produced for Malatesta Novello around the middle of the $15^{\text {th }}$ century; 20 in-quarto codices dating from the $9^{\text {th }}$ to $15^{\text {th }}$ centuries; a sample of charters from Lucca ( 292 items) dating from the $13^{\text {th }}$ to $14^{\text {th }}$ centuries, together with the Lucca 490 codex, of the same period. See Bianchi et al. 1993b, 99-104.

72 See Bianchi et al. 1993a, passim. In particular, see p. 183 of the same title. It should also be emphasised that with respect to the Lucca charters, the thickness seems to be closely linked not only to factors of a material nature (dimensions and script type), but also to geographic (city, rural area) and social factors (the social status of authors and writers). Regarding the significance of the subscriptions on the documents from Lucca, see also the opinion of Supino Martini 1992.

73 Bischoff 1991; Bischoff 1993.

74 Bischoff 1991, 127-129; Bischoff 1993, 77-82.

75 Bischoff 1994, 92.

76 Bischoff 1991, 129-133; Bischoff 1993, 86-89. 
ple, Casin. 132, ${ }^{77}$ the noted Cassinese exemplar of Rabanus Maurus, strays very far from the general standards known to us up to now, since it contains exceedingly thin parchment ${ }^{78}$-much thinner, indeed, than its majestic decorative apparatus would lead one to suppose, and a far cry from the average value recorded in many codices dating from the same period. Indeed, the parchment of the Rabanus Maurus codex is thinner not only than the average gauge recorded in a group of about 300 manuscripts (during an investigation of Italian production of the $11^{\text {th }}$ century), ${ }^{79}$ but also than that of Beneventan codices of the same size ${ }^{80}$ studied in the same research project. ${ }^{81}$ We are not yet in a position to provide a comprehensive picture of $11^{\text {th }}$-century Cassinese production, but through the study of a particular type of object-the liturgical rolls of the Exultet, which are typical products of the Beneventan area-we have certainly learnt how the good quality of a product of this type does not depend on its greater or lesser thinness, as much as on the average degree of uniformity of the various parts it is composed of, whether these be considered individually or as a whole. ${ }^{82}$

This brief overview of the potential that the study of a variable such as thickness holds is intended simply to encourage an investigation into the various quiring types and, above all, to provide us with another key that may contribute to explaining the shift from employing quaternions to the use of thicker quires.

\section{Quiring and other parameters}

One of the questions that we posed when planning our research concerns the way and extent to which quiring interacts with other variables. In the present contribution, it seems sensible to limit our discussion to those parameters which have shown themselves to be of the most significance in relation to quiring, or at least indicative enough to enable us to identify sufficiently clear trends. Such parameters include the manuscript's support, format, text typology and layout. Size will also be considered, since it may be helpful and of some interest to report the re-

77 The particular conditions under which this example was studied, as well as the use of a magnetic induction micrometer made it possible to carry out a very detailed archaeological investigation. See Di Majo et al. 1994, passim.

78 The average thickness is 174.01 thousandths of a millimetre. See Di Majo et al. 1994, 91.

79 Bianchi et al. 1993b, 390.

80 The size of a manuscript is determined by its semi-perimeter $(\mathrm{L}+\mathrm{H})$.

81 Bianchi et al. 1993b, 393.

82 Palma 1994, passim. 
sults obtained, even if our attempt to compare this parameter with quiring did not turn out to be particularly fruitful.

\subsection{Quiring and the writing support}

Among the characteristics that appear to be directly correlatable to quiring is the writing support. Indeed, we have already stressed its importance when we outlined a picture of the development of quiring in the $14^{\text {th }}$ and $15^{\text {th }}$ centuries.

If we create a sub-category of codices that date to the $14^{\text {th }}$ century based on the material they are composed of, in parchment ones-given the prevalence of this support in the sample-we observe exactly the same quiring trend as the one that emerged from the overall picture. In fact, in the first half of the century the senion was still used in well over half of the total output, whereas in the second half its use declined drastically (29.4\%) in the face of an increase in the use of the quaternion, which rose from $30.2 \%$ to $50.1 \%$ (see Tab. 13).

\begin{tabular}{|c|c|c|c|c|}
\hline \multicolumn{4}{|c|}{ Parchment, $15^{\text {th }}$ century, first / second half } & (tab. 13) \\
\hline & Firs & thalf & Second half & Total \\
\hline Predominant quiring & & $\%$ & $\%$ & $\%$ \\
\hline $1^{-1}$ & $\left.\right|^{1}$ & |0.6 & $\left.1^{1} \quad\right|^{0.3}$ & $\left.\left.\right|^{2} \quad\right|^{0.4}$ \\
\hline ।" & $\left.\right|^{1}$ & |0.6 & $\left.\left.\right|^{1} \quad\right|^{0.3}$ & $\left.\left.\right|^{2} \quad\right|^{0.4}$ \\
\hline |III & 0 & 0 & $\left.\left.\right|^{2} \quad\right|^{0.6}$ & $\left.\left.\right|^{2} \quad\right|^{0.4}$ \\
\hline , IV & 154 & |30.2 & |179,50.1 & |233,43.5 \\
\hline ।V & $1^{22}$ & |12.3 & |65 18.2 & $\left.\right|^{87}, 16.2$ \\
\hline , VI & 99 & |55.3 & |105, 29.4 & |204 38 \\
\hline , VII & $\left.\right|^{1}$ & 0.5 & $\left.1^{0} \quad\right|^{0}$ & $\left.\left.\right|^{1} \quad\right|^{0.2}$ \\
\hline ,VIII & & 10.5 & $1^{3} \quad 1^{0.8}$ & $\left.\left.\right|^{4} \quad\right|^{0.7}$ \\
\hline |XII & $1^{0}$ & $1^{0}$ & $\left.\left.\right|^{1} \quad\right|^{0.3}$ & $\left.\left.\right|^{1} \quad\right|^{0.2}$ \\
\hline Total & 179 & 100 & |357, 100 & 100 1036 \\
\hline
\end{tabular}

Tab. 13: Parchment, $15^{\text {th }}$ century, first / second half 
The landscape with respect to paper manuscripts looks very different in the second half of the century. ${ }^{83}$ The adoption of paper as a writing support involved manufacturing solutions based on manifestly different thinking from that applied during the same period for parchment manuscripts. In fact, an incontrovertible tendency to favour thicker quires emerges, to the extent that senions are employed in $46.4 \%$ of overall production, whilst quinions account for $32 \%$, whereas quaternions do not even amount to $9 \%$ of the total output. Quires composed of nine or more bifolia also appear (see Tab. 14).

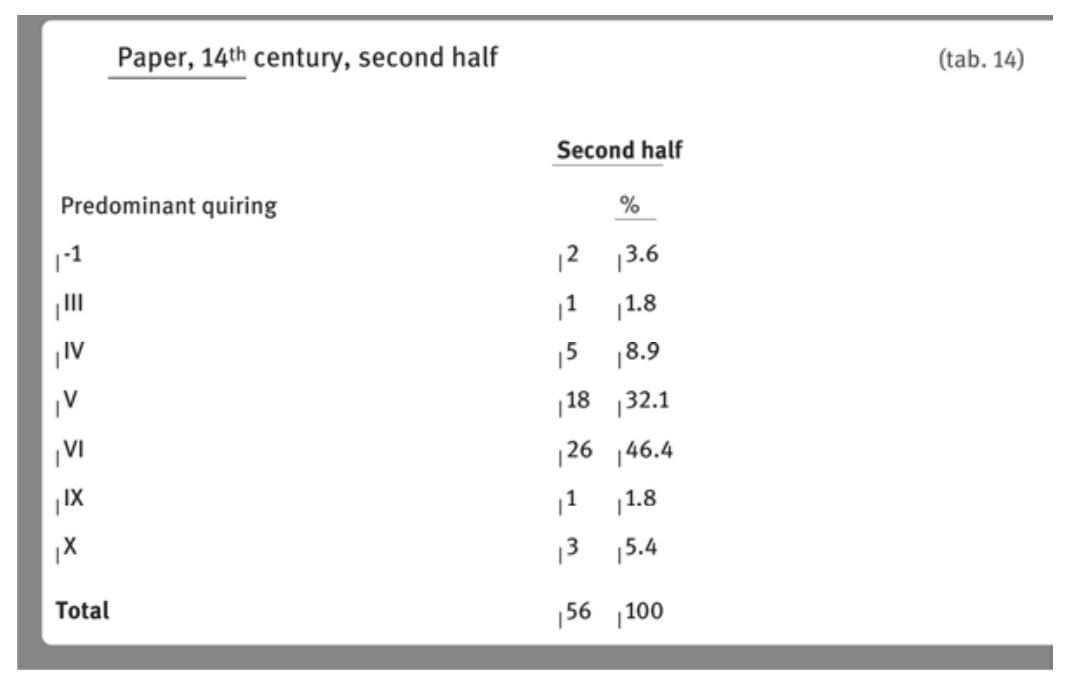

Tab. 14: Paper, $14^{\text {th }}$ century, second half

In the first half of the $15^{\text {th }}$ century the phenomenon becomes more apparent, inasmuch as parchment codices are mostly composed of quaternions (approximately 68\%), whilst quinions and senions are adopted in a little more than $18 \%$ and $13 \%$ of cases, respectively. The second half of the century sees a slight decrease (of about 10\%) of codices composed of quaternions in the face of a clear increase in the use of quinions, which, as we know, is chiefly owed to the Italian context. On the other hand, the senion assumes an ever more marginal position in the sphere of parchment production (see Tab. 15).

83 The number of items in the sample for the first half of the century is insufficient for the purposes of statistical analysis. 
Parchment, $15^{\text {th }}$ century, first / second half

(tab. 15)

\begin{tabular}{|c|c|c|c|}
\hline & First half & Second half & Total \\
\hline Predominant quiring & $\%$ & $\%$ & $\%$ \\
\hline |III & $\left.\left.\right|^{1} \quad\right|^{0.3}$ & $\left.\left.\right|^{2} \quad\right|^{0.3}$ & $\left.1^{3} \quad\right|^{0.3}$ \\
\hline ।IV & |207,68.1 & |412,58.3 & |619,61.2 \\
\hline । $\mathrm{v}$ & |55 |18.1 & |238 33.7 & |293 |29 \\
\hline ।VI & $1^{40}, 13.2$ & $\left.\left.\right|^{52} \quad\right|^{7.3}$ & |92 9.1 \\
\hline ।VII & $।^{0} \quad ।^{0}$ & $\left.\left.\right|^{1} \quad\right|^{0.1}$ & $\left.\left.\right|^{1} \quad\right|^{0.1}$ \\
\hline |VIII & $\left.\left.\right|^{1} \quad\right|^{0.3}$ & $\left.\left.\right|^{2} \quad\right|^{0.3}$ & $\left.1^{3} \quad\right|^{0.3}$ \\
\hline Total & |304,100 & |707 100 & |10:1,100 \\
\hline
\end{tabular}

Tab. 15: Parchment, $15^{\text {th }}$ century, first / second half

The distribution of quiring in paper codices shows the opposite trend. In the first half of the $15^{\text {th }}$ century the senion is employed in almost half of the total production (48.3\%). Quinions are also frequently used, accounting for $37.2 \%$, whilst quaternions represent just $7.1 \%$ of the total. In the second half of the century we see some variation in the numbers of the different kinds of quire (for example, quinions decrease from $37.2 \%$ to $32.3 \%$ ), but the overall trend remains unchanged (see Tab. 16).

To complete the picture of $15^{\text {th }}$-century production, we have only to consider the codices which present a mélange, more or less rationally structured, of two supports, which is to say manuscripts composed of mixed quires, ${ }^{84}$ and those with some quires made of paper and others of parchment. ${ }^{85}$ In our sample, the number of manuscripts assembled in one or the other way is not particularly significant in the first half of the century. ${ }^{86}$

84 In other words, paper codices with the outer and/or inner bifolium made from parchment. 85 For an in-depth analysis of the set of problems in relation to codices containing mixed quires, see Bianchi et al. 1994.

86 The use of mixed quires is exceedingly rare up until the last decades of the $14^{\text {th }}$ century. See Bianchi et al. 1994, 265. 


\begin{tabular}{|c|c|c|c|}
\hline \multicolumn{3}{|c|}{ Paper, $15^{\text {th }}$ century, first / second half } & (tab. 16) \\
\hline & First half & Second half & Total \\
\hline Predominant quiring & $\%$ & $\%$ & $\%$ \\
\hline $1^{-1}$ & $1^{0} \quad 1^{0}$ & $\left.\left.\right|^{11} \quad\right|^{2.3}$ & $\left.\left.\right|^{11} \quad\right|^{1.6}$ \\
\hline ।III & $\left.।^{1} \quad\right|^{0.6}$ & $\left.\left.\right|^{1} \quad\right|^{0.2}$ & $\left.1^{2} \quad\right|^{0.3}$ \\
\hline IV & $1^{13} \quad ।^{7.1}$ & $1^{34} \quad 1^{6.9}$ & $1^{47} \quad ।^{7}$ \\
\hline । & , 67 , 37.2 & , 159, 32.3 & |226,33.6 \\
\hline । $\mathrm{VI}$ & |87 $\quad 48.3$ & । $258,52.4$ & ।345,51.4 \\
\hline ¡VII & $।^{1} \quad ।^{0.6}$ & $\left.1^{4} \quad\right|^{0.8}$ & $\left.1^{5} \quad\right|^{0.8}$ \\
\hline ।VIII & $1^{9} \quad 1^{5}$ & $1^{17} \quad 3.5$ & $\mathbf{1}^{26}, 3.9$ \\
\hline${ }_{1} \mathrm{x}$ & $\left.\left.\right|^{1} \quad\right|^{0.6}$ & $\left.1^{4} \quad\right|^{0.8}$ & $\left.1^{5} \quad\right|^{0.7}$ \\
\hline XII & $\left.\left.\right|^{1} \quad\right|^{0.6}$ & $\left.।^{4} \quad\right|^{0.8}$ & $\left.1^{5} \quad\right|^{0.7}$ \\
\hline Total & |180, 100 & ।492,100 & |672, 100 \\
\hline
\end{tabular}

Tab. 16: Paper, $15^{\text {th }}$ century, first / second half

However, it should also be noted that in codices whose quires are made either from paper or from parchment, their composition ranges from quaternions to nonions, whereas in those composed of mixed quires there appears to be a preference for the senion. During the second half of the $15^{\text {th }}$ century the former are still made from a wide range of quire types-ranging from quaternions to octonions-whereas the latter continue to favour senions, and then octonions ${ }^{87}$ (see Tab. 17). Therefore, the codices formed from mixed quires follow the same pattern as that seen in the paper ones.

Once the overall trend in quiring in relation to the material has been examined, we shall attempt to discover the way in which the phenomenon manifested itself at a local, or rather, national level, by means of an analysis of each country's production in the $15^{\text {th }}$ century ${ }^{88}$ Production of parchment manuscripts in England mostly centres on the quaternion, whose diffusion increased in the second part of the century-shifting, in fact, from $78.1 \%$ in the first half of the $15^{\text {th }}$ century to $82.4 \%$ in the second-whilst the number of codices structured in senions decreased and accounts for around $10 \%$ of the overall sample (see Tab. 18).

87 To get an idea of the distribution of the various types of quires used in mixed Latin, Greek and Hebrew manuscripts, see Bianchi et al. 1994, 276-280.

88 For the $14^{\text {th }}$ century, the sample of paper manuscripts is too sparse, hence it is not possible to create subdivisions between countries. 
Parchment / paper and mixed, $15^{\text {th }}$ century, first / second half

(tab. 17)

\begin{tabular}{|c|c|c|c|c|c|c|c|c|c|c|c|c|c|c|}
\hline \multirow{2}{*}{$\begin{array}{l}\text { Predom. } \\
\text { quiring }\end{array}$} & \multicolumn{2}{|c|}{ First half } & \multirow[b]{2}{*}{$\mathrm{Mi}^{\star}$} & \multirow[b]{2}{*}{$\%$} & \multirow[b]{2}{*}{ Tot. } & \multirow[b]{2}{*}{$\%$} & \multicolumn{3}{|c|}{ Second half } & \multirow[b]{2}{*}{$\%$} & \multirow[b]{2}{*}{ Tot. } & \multirow[b]{2}{*}{$\%$} & \multicolumn{2}{|c|}{ Total } \\
\hline & $\mathrm{P}-\mathrm{P}$ & & & & & & $P-P^{-}$ & $\%$ & $\mathrm{Mi}^{\star}$ & & & & $15^{\text {th }}$ & $\%$ \\
\hline ,IV & $\left.\right|^{1}$ & 12.5ر & $\left.\right|^{0}$ & $1^{0}$ & $\left.\right|^{1}$ & |6.2 & $1^{4}$ & $\left.\right|^{25}$ & $\left.\right|^{1}$ & $1^{4}$ & $1^{5}$ & $\left.\right|^{12.2}$ & |6 & |0.5 \\
\hline$\left.\right|^{\vee}$ & $1^{2}$ & ,25 & $\left.\right|^{1}$ & 12.5 & $1^{3}$ & 18.8 & $1^{5}$ & |31.3 & $1^{2}$ & $\left.\right|^{8}$ & $1^{7}$ & | 17.1 & |10 & | 17.5 \\
\hline , VI & $1^{2}$ & $1^{25}$ & $1^{5}$ & |62.5 & $\mathrm{I}^{7}$ & $1^{43.8}$ & $1^{3}$ & | 18.7 & $1^{15}$ & 160 & |18 & |43.9 & |25 & | 43.9 \\
\hline |VII & $\left.\right|^{1}$ & 12.5ر & $1^{0}$ & $1^{0}$ & $\left.\right|^{1}$ & |6.2 & $\left.\right|^{1}$ & |6.3 & $\left.\right|^{1}$ & $1^{4}$ & $1^{2}$ & | 4.9 & $1^{3}$ & $1^{5.3}$ \\
\hline ,VIII & | 1 & 12.5 & $1^{0}$ & $1^{0}$ & $\left.\right|^{1}$ & |6.2 & $1^{3}$ & | 18.7 & $1^{4}$ & $\left.\right|^{16}$ & $1^{7}$ & |17.1 & $\left.\right|^{8}$ & $\left.\right|^{14}$ \\
\hline IX & $\left.\right|^{1}$ & 12.5ر & $\left.\right|^{1}$ & 12.5 & $1^{2}$ & 12.6 رן & $1^{0}$ & $1^{0}$ & $1^{0}$ & $1^{0}$ & $1^{0}$ & $1^{0}$ & $1^{2}$ & 3.5 \\
\hline${ }_{1} x$ & $1^{0}$ & $1^{0}$ & $1^{0}$ & $1^{0}$ & $1^{0}$ & $1^{0}$ & 10 & $1^{0}$ & $\left.\right|^{1}$ & $1^{4}$ & $\left.\right|^{1}$ & $\left.\right|^{2.4}$ & |1 & $\left.\right|^{1.8}$ \\
\hline${ }_{\mid} \mathrm{XII}$ & $1^{0}$ & $1^{0}$ & $\left.\right|^{1}$ & 12.5 & $\left.\right|^{1}$ & |6.2 & $1^{0}$ & $1^{0}$ & $\left.\right|^{1}$ & $1^{4}$ & $\left.\right|^{1}$ & |2.4 & $1^{2}$ & 3.5 \\
\hline Total & 8 & 100رן & 8 & 100ן & 16 & 100رן & |16 & 100 & $1^{25}$ & 100 & $1^{41}$ & 100 & , 57 & |100 \\
\hline
\end{tabular}

Tab. 17: Parchment / paper and mixed, $15^{\text {th }}$ century, first / second half

England. Parchment, 15th century, first / second half

(tab. 18)

\begin{tabular}{|c|c|c|c|c|}
\hline \multirow[b]{2}{*}{ Predominant quiring } & First half & Second half & \multicolumn{2}{|c|}{ Total } \\
\hline & $\%$ & $\%$ & & $\%$ \\
\hline |III & $\left.\left.\right|^{1} \quad\right|^{0.6}$ & $\left.\left.\right|^{0} \quad\right|^{0}$ & $\left.\right|^{1}$ & 0.3 \\
\hline IV & 107, 78.1 & |141 82.4 & |248 & ן 80.5 \\
\hline v & $\left.1^{3} \quad\right|^{2.2}$ & $\left.1^{9} \quad\right|^{5.3}$ & $\left.\right|^{12}$ & | 3.9 \\
\hline $\mathrm{VI}$ & | 18.3 & |19 & $1^{44}$ & 14.3 \\
\hline VII & $1^{0} \quad 1^{0}$ & $\left.\left.\right|^{1} \quad\right|^{0.6}$ & $\left.\right|^{1}$ & | 0.3 \\
\hline VIII & $\left.\right|^{1} \quad ।^{0.7}$ & $\left.\left.\right|^{1} \quad\right|^{0.6}$ & $1^{2}$ & | 0.7 \\
\hline Total & 100, 137ן & |100 171 & 308 & |100 \\
\hline
\end{tabular}

Tab. 18: England. Parchment, $15^{\text {th }}$ century, first / second half

The distribution of quires in paper codices certainly does not change in a radical way, since quaternions remain very well represented (this observation relates to the second half of the century, given that the sample for the first half of the 
century is of little statistical significance). ${ }^{89}$ Indeed, they account for almost one quarter of total production, but in any event it is possible to confirm that more than a third of the codices are composed of senions, and that about another third contain quires formed from seven or more bifolia (see Tab. 19).

\begin{tabular}{|c|c|c|c|c|c|c|}
\hline \multicolumn{5}{|c|}{ England. Paper, 15th century, first / second half } & \multicolumn{2}{|c|}{ (tab. 19) } \\
\hline & & thalf & Sec & ond half & Tota & \\
\hline Predominant quiring & & $\%$ & & $\%$ & & $\%$ \\
\hline $1^{-1}$ & $1^{0}$ & $1^{0}$ & $1^{2}$ & |6.1 & $1^{2}$ & $1^{4.8}$ \\
\hline IV & $1^{5}$ & 155.6 & 8 & 24.2 & $\left.\right|^{13}$ & | 30.9 \\
\hline , VI & $\left.\right|^{1}$ & |11.1 & $\left.\right|^{12}$ & |36.3 & $\left.\right|^{13}$ & | 30.9 \\
\hline ।VII & $1^{0}$ & $1^{0}$ & $1^{2}$ & 16.1 & $1^{2}$ & $1^{4.8}$ \\
\hline |VIII & $1^{2}$ & 22.2 & $1^{4}$ & |12.1 & 16 & $\left.\right|^{14.3}$ \\
\hline${ }_{1} x$ & $1^{0}$ & $1^{0}$ & $1^{2}$ & |6.1 & $\left.\right|^{2}$ & $1^{4.8}$ \\
\hline |XII & $\left.\right|^{1}$ & |11.1 & $1^{3}$ & |9.1 & $1^{4}$ & |9.5 \\
\hline Total & 9 & |100 & $\left.\right|^{33}$ & 100 & $1^{42}$ & 100 \\
\hline
\end{tabular}

Tab. 19: England. Paper, $15^{\text {th }}$ century, first / second half

In France, parchment codices are typically assembled from quaternions, whose level of diffusion exceeds $90 \%$ in the second half of the century, whereas the percentage of codices composed of different types of quire-senions includedis very limited (see Tab. 20). Production in paper is not represented in the first half of the century in our sample, which is rather poor in this respect. Nevertheless, one can identify a considerable preference for the senion, which is seen in 7 out of 12 cases. In the second half of the century the tendency to adopt the senion in paper is plain to see: indeed, the number of codices composed of senions exceeds $60 \%$ of the total, whilst manuscripts created from quaternions and quinions both account for a little under $12 \%$. Also seen are quires consisting of eight or more bifolia, and very thick and irregular quires which are typical of paper manuscripts (see Tab. 21).

89 Although of 9 paper codices dating to this period 5 (more than half, then) are composed of quaternions, one is composed of senions, 2 are composed of octonions, and one is composed of quires assembled from twelve bifolia. 
France. Parchment, 15th century, first / second half

\begin{tabular}{|c|c|c|c|c|c|}
\hline \multirow[b]{2}{*}{ Predominant quiring } & \multicolumn{2}{|c|}{ First half } & Second half & \multicolumn{2}{|c|}{ Total } \\
\hline & & $\%$ & $\%$ & & $\%$ \\
\hline , IV & $1^{50}$ & | 87.7 & 90.9 | 129 & 179 & ן90 \\
\hline ¡V & $1^{0}$ & $1^{0}$ & $\left.\left.\right|^{2} \quad\right|^{1.4}$ & $1^{2}$ & $\left.\right|^{1}$ \\
\hline ।VI & $1^{7}$ & |12.3 & $\left.\right|^{10} \quad ।^{7}$ & $\left.\right|^{17}$ & | 8.5 \\
\hline |VIII & $1^{0}$ & $1^{0}$ & $\left.\left.\right|^{1} \quad\right|^{0.7}$ & $\left.\right|^{1}$ & 0.5 \\
\hline Total & , 57 & |100 & |142, 100 & 199 & 100 \\
\hline
\end{tabular}

Tab. 20: France. Parchment, $15^{\text {th }}$ century, first / second half

France. Paper, $15^{\text {th }}$ century, first / second half

\begin{tabular}{|c|c|c|c|c|c|c|}
\hline \multirow[b]{2}{*}{ Predominant quiring } & \multicolumn{2}{|c|}{ First half } & \multicolumn{2}{|c|}{ Second half } & \multicolumn{2}{|c|}{ Total } \\
\hline & & $\%$ & & $\%$ & & $\%$ \\
\hline $1^{-1}$ & 10 & $1^{0}$ & $1^{3}$ & 17.1 & $1^{3}$ & $1^{5.5}$ \\
\hline IV & $1^{2}$ & |16.7 & $1^{5}$ & |11.9 & $1^{7}$ & 13 \\
\hline , v & 10 & 10 & $1^{5}$ & 11.9 & $1^{5}$ & |9.3 \\
\hline , VI & $1^{7}$ & |58.3 & $1^{26}$ & |61.9 & $1^{33}$ & |61.1 \\
\hline ,VIII & $1^{2}$ & |16.7 & $1^{2}$ & |4.8 & $1^{4}$ & 17.4 \\
\hline${ }_{1} x$ & $\left.\right|^{1}$ & 8.3 & $\left.\right|^{1}$ & $1^{2.4}$ & $1^{2}$ & 13.7 \\
\hline Total & 12 & 100 & 42 & 100 & $1^{54}$ & 100 \\
\hline
\end{tabular}

Tab. 21: France. Paper, $15^{\text {th }}$ century, first / second half

The situation outlined above, for both parchment and paper production, largely confirms what Bozzolo and Ornato illustrated in their essay La constitution des cahiers dans les manuscrits en papier d'origine française et le problème de l'imposition: ${ }^{90}$ in the section dedicated to an examination of various typologies of quire, the two scholars show how the senion is by far the predominant type in

90 Bozzolo / Ornato 1980, 124-211. 
paper manuscripts, whereas it is almost absent in parchment production, which remains dominated by the quaternions. ${ }^{91}$

Parchment codices originating from Italy are mostly composed of quinions, whose presence increases from $63.1 \%$ in the first half of the $15^{\text {th }}$ century to $78.2 \%$ in the second, obviously subtracting the share of quaternions, which decrease from a rate of $32.3 \%$ to one of just $19 \%$ (see Tab. 22). The preference for the quinion also manifests itself in paper codices: in fact, in the first half of the century $65 \%$ of these were made of quinions, and a little under $64 \%$ in the second half. However, the considerable difference between paper and parchment codices manifests itself in the type of quire that fills the share of production left free by the quinion: in fact, the number paper codices composed of quaternions proves to be markedly low, whilst those composed of senions reappear in both halves of the century, at rates of diffusion of $23.8 \%$ and $17.9 \%$, respectively. One can therefore reasonably suppose that the introduction of paper changed the quiring landscape in Italy as well: the quinion is certainly the preferred option for both parchment and paper, but in the former case it is flanked by the quaternion, whilst in the latter by the senion. Other types of thick quire are met with in paper manuscripts, such as octonions and those composed of an even greater number of bifolia, which were not utilised in parchment volumes.



Tab. 22: Italy. Parchment, $15^{\text {th }}$ century, first / second half

91 Bozzolo / Ornato 1980, 131-132. 


\begin{tabular}{|c|c|c|c|c|c|}
\hline \multirow[b]{2}{*}{ Predominant quiring } & \multicolumn{2}{|c|}{ First half } & Second half & \multicolumn{2}{|c|}{ Total } \\
\hline & & $\%$ & $\%$ & & $\%$ \\
\hline $1^{-1}$ & $1^{0}$ & $1^{0}$ & $\left.1^{5} \quad\right|^{2.7}$ & $1^{5}$ & $\left.\right|^{1.9}$ \\
\hline |'II & $\left.\right|^{1}$ & 1.2 & $\left.\left.\right|^{1} \quad\right|^{0.5}$ & $1^{2}$ & 0.8 \\
\hline IV & $1^{4}$ & $1^{5}$ & $\left.\left.\right|^{14} \quad\right|^{7.6}$ & |18 & 6.8 \\
\hline ।V & $1^{52}$ & 165 & | 118 , 63.8 & $\left.\right|^{170}$ & |64.1 \\
\hline , $\mathrm{VI}$ & $\left.\right|^{19}$ & 23.8 & $\left.\right|^{33} \quad$ 17.9 & $1^{52}$ & | 19.6 \\
\hline , VII & $\left.\right|^{1}$ & 1.2 & $\left.\left.\right|^{2} \quad\right|^{1.1}$ & $1^{3}$ & $\left.\right|^{1.1}$ \\
\hline |VIII & $1^{3}$ & |3.8 & $\left.\left.\right|^{10}\right|^{5.4}$ & 13 & $1^{4.9}$ \\
\hline${ }_{1} \mathrm{x}$ & 10 & 10 & $\left.\left.\right|^{1} \quad\right|^{0.5}$ & $\left.\right|^{1}$ & | 0.4 \\
\hline |XII & 10 & $1^{0}$ & $।^{1} \quad ।^{0.5}$ & $।^{1}$ & 0.4 \\
\hline Total & 80 & |100 & |185, 100 & 265 & |100 \\
\hline
\end{tabular}

Tab. 23: Italy. Paper, $15^{\text {th }}$ century, first / second half

A well-delineated situation emerges from our examination of the German area: manuscript production is centred on paper volumes, and these are largely structured in senions ${ }^{92}$ In the first half of the century manuscripts composed of senions account for $87 \%$ of production. Quaternions are almost completely absent, whilst quinions amount to almost $9 \%$ of production, and subsequently exceed $10 \%$ in the second half of the century (see Tab. 24). As soon as one turns one's attention away from paper and focuses on parchment, quaternions reappear. These prove to be the quire of choice both in the first half of the century, where they are seen in 6 out of 14 items, ${ }^{93}$ and in the second half, in which they account for $57 \%$ of the total production. Quinions are also well represented: we find 5 occurrences in 14 in the first half of the century, whereas they reach a rate of diffusion of about $22 \%$ in the second half (see Tab. 25). The strong presence of senions in the German area is therefore linked to the need to produce paper codices, because as the type of support changes, quaternions return and play a dominant role.

92 See Bozzolo 1994, 230-232.

93 The total number of parchment codices in the sample that date from this period is rather low, but the predominance of codices structured in quaternions and quinions in comparison to those composed of senions is indisputable. 
Germany. Paper, $15^{\text {th }}$ century, first / second half

(tab. 24)

\begin{tabular}{|c|c|c|c|c|}
\hline \multirow[b]{2}{*}{ Predominant quiring } & First half & Second half & \multicolumn{2}{|c|}{ Total } \\
\hline & $\%$ & $\%$ & & $\%$ \\
\hline |IV & $\left.\left.\right|^{0} \quad\right|^{0}$ & $\left.1^{5} \quad\right|^{2.8}$ & $1^{5}$ & 2.2 \\
\hline ।V & $\left.\right|^{4} \quad 8.7$ & $\left.\left.\right|^{20}\right|^{11}$ & $1^{24}$ & 10.6 \\
\hline , VI & $\left.\right|^{40} \quad 87$ & | 156 ,86.2 & |196 & 86.3 \\
\hline |VIII & $1^{2} \quad 1^{4.3}$ & $।^{0} \quad ।^{0}$ & $1^{2}$ & 0.9 \\
\hline Total & | 100 & |181,100 & 227 & 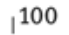 \\
\hline
\end{tabular}

Tab. 24: Germany. Paper, $15^{\text {th }}$ century, first / second half

Germany. Parchment, $15^{\text {th }}$ century, first / second half

\begin{tabular}{|c|c|c|c|c|c|}
\hline \multirow[b]{2}{*}{ Predominant quiring } & \multicolumn{2}{|c|}{ First half } & Second half & \multicolumn{2}{|c|}{ Total } \\
\hline & & $\%$ & $\%$ & & $\%$ \\
\hline IV & $1^{6}$ & 142.9 & $\left.\right|^{28} \quad$,57.1 & 34 & \rfloor$^{54}$ \\
\hline । $v$ & $1^{5}$ & |35.7 & |11 22.5 & 16 & 25.4 \\
\hline ।VI & $1^{3}$ & 21.4 & $\left.\left.\right|^{10} \quad\right|^{20.4}$ & $\left.\right|^{13}$ & $\left.\right|^{20.6}$ \\
\hline Total & 14 & |100 & |49,100 & 63 & 100 \\
\hline
\end{tabular}

Tab. 25: Germany. Parchment, $15^{\text {th }}$ century, first / second half

With respect to the Low Countries, our sample is mostly composed of parchment codices-paper codices are scantly represented-which, as in the rest of Europe, are mostly composed of quaternions (see Tab. 26). The number of paper codices in the sample is statistically insignificant in the first half of the century; however, we can confirm that the 8 volumes dating from this period are all composed of senions. In the second half of the century the bulk of codices are composed of senions (76.2\%), with the number of volumes structured in quinions amounting to $20 \% .^{94}$

94 The number of codices that represent this period is 29 . 
Low Countries. Parchment, $15^{\text {th }}$ century, first / second half

\begin{tabular}{|c|c|c|c|c|}
\hline \multirow{2}{*}{ Predominant quiring } & First half & Second half & \multicolumn{2}{|c|}{ Total } \\
\hline & $\%$ & $\%$ & & $\%$ \\
\hline |'II & $1^{0} \quad 1^{0}$ & $\left.1^{2}\right|^{3}$ & $1^{2}$ & $1^{2.3}$ \\
\hline ।IV & $\left.\left.\right|^{17} \quad\right|^{85}$ & |60 188.2 & $\mathrm{I}^{77}$ & 87.5 \\
\hline । $v$ & $\left.1^{3} \quad\right|^{15}$ & $1^{3} \quad 1^{4.4}$ & $1^{6}$ & 6.8 \\
\hline ।VI & $1^{0} \quad ।^{0}$ & $1^{3} \quad 1^{4.4}$ & $1^{3}$ & | 3.4 \\
\hline Total & $\left.\left.\right|^{20}\right|^{100}$ & |68 100 & 88 & |100 \\
\hline
\end{tabular}

Tab. 26: Low Countries. Parchment, $15^{\text {th }}$ century, first / second half

The fundamental role played by the type of support in determining the choices made in the manufacture of a codex has emerged very clearly from the analysis we have just carried out. The period of the senion's diffusion-as we have already highlighted-stretches from about 1250 to 1350 . In the second half of the century the quaternion again reaches an apogee (this type of quire was the most commonly used in codices made in the early centuries of the first millennium).

Needless to say, the observations that we shall now put forward relate to the manufacture of parchment codices, given that paper codices seem to have been conceived of based on a different way of thinking. Indeed, the tradition of structuring codices in quaternions was not embraced by the world of paper, which chiefly focused on thicker types of quire, such as senions and quinions, and eventually adopted truly substantial and irregular ones.

What, then, were the considerations which led to certain choices being made? Could it be-as Bozzolo and Ornato have shown at various times ${ }^{95}$-that paper was considered a second-rate material (and certainly less robust and much more perishable compared to parchment), and therefore the making of thicker quires might have fulfilled the need for greater durability and solidity?

In fact, if we observe this process through the eyes of the modern restorer, in relation to the solidity of the binding in particular, such a hypothesis does not appear to be altogether sustainable, given that the thicker the quires are, the harder it is to assemble them into a single block that will have a certain amount of strength. In actual fact, we are not able to establish with certainty the reasons

95 Bozzolo / Ornato 1980, 70-72, 133. 
that led to the preference for heftily constructed quires. One can hypothesise that a quire composed of multiple bifolia offered a guarantee-or at least, the impression-of greater stability and durability, regardless of the challenges presented by the binding process. ${ }^{96}$

However, we should not forget that the paper codex developed an entirely different appearance-one which was 'poorer' in comparison to its parchment cousin. Having its roots in the rough book or notebook, the paper codex enjoyed freedom from the laws that governed the production of the parchment manuscript, which had a more noble, and perhaps, precisely for this reason, more 'codified' use. For this reason, the paper codex was not affected by the traditional preference for quires structured as quaternions, and instead assumed forms that seemed better suited to the purpose to which it would be put, or, perhaps, to the status it held.

The remarks made above relate to Latin paper books, because, as we well know, the Greco-Byzantine world remained closely wed to the quaternion, also when it came to paper codices, even if the appearance of the new material contributed to generating an increased number of assembly techniques. In the Renaissance the panorama of Greek codices-which is predominantly populated by paper volumes-also presents other types of quire, although the quaternion remains the most widespread option. ${ }^{97}$ Jean Irigoin has noted how some Greek scribes who were active in Italy during the $15^{\text {th }}$ century adopted the quinion when they were writing on parchment, but reverted to the quaternion for paper manuscripts. ${ }^{98}$

A recent investigation of the characteristics and typologies of Islamic manuscripts $^{99}$ has revealed how Eastern and Western Muslims adopted different materials for the manufacture of books. ${ }^{100}$ In the context of this contribution, it should be pointed out that one of the most important differences between the two areas of production concerns the composition of quires in parchment manu-

96 Indeed, the application of parchment reinforcement along the fold in paper quires could support the hypothesis that little confidence was placed in the strength of paper. See Bozzolo / Ornato 1980, 133.

97 See Canart 1980-1981, 77; Bianchi et al. 1994, 105, relating to a survey of 100 Greek Vatican codices dating from the $13^{\text {th }}$ to $16^{\text {th }}$ centuries.

98 Irigoin 1998, 7. In this contribution, the scholar examines the way in which quires were arranged in Greek codices in relation to the support (parchment, paper, mixed).

99 Orsatti 1993, 325-326.

100 The West encompassed the areas lying to the west of Egypt extending as far as Spain. The East remains undifferentiated, although in this region, too, one can identify different codicological zones. See Orsatti 1993, 323-324. 
scripts. In the East, these prove to be predominantly structured in quinions, whereas in the Western area they are assembled from ternions, a use that seems to be peculiar to the Islamic codex. ${ }^{101}$ Indeed, Jewish production in the same area is characterised by the quaternion, with the sole exception of Toledo, where parchment codices composed of ternions were produced. ${ }^{102}$ Conversely, Western Hebrew codices made from paper favoured thick quires; indeed, manuscripts composed of senions and octonions predominate, even if there is no lack of codices constructed from quires composed of 4, 5, 7 and more bifolia. ${ }^{103}$ One also encounters a remarkable variety of different types of quire in paper manuscripts of Arab origin, ${ }^{104}$ which distinguish themselves from manuscripts of North African origin where, at least in the case of the Koran, trust was largely placed in the quinion. ${ }^{105}$ In the East, Jewish production-as much in paper as in parchment-was also centred on the quinion, as it was in Islamic production, with the exception of codices originating from Iran and Uzbekistan, which were for the most part assembled from quaternions. ${ }^{106}$ Paper therefore provides a rather varied panorama in the Western Jewish and Islamic worlds, but one which in any event leans towards rather thick quires (this observation is valid, above all, with respect to Hebrew manuscripts, which have been studied more closely).

The hypothesis that holds paper to be more perishable and less reliable than parchment appears to be supported by the creation of codices made from mixed quires-that is, as we have already said, of paper quires, but with the inner or outer bifolium, or both, made from parchment, most likely with the aim of endowing the quire with greater solidity and durability. ${ }^{107}$ The authors of Une recherche sur les manuscrits à cahiers mixtes say of France and Italy (the former favouring the senion, the latter the quinion): 'Mais on peut se demander si le glissement vers le septénions et les octonions constaté chez les mixtes ne

101 See Orsatti 1993, 325-326.

102 Hebrew parchment manuscripts are essentially composed of quaternions in Ashkenaz and Sefarad (which of course includes Spain) and in Byzantium; meanwhile, in Italy and the East (with the exception of Persia and Uzbekistan) manuscripts are composed of quinions. See BeitArié 1981, 12-19 (for the definition of areas) and 43-49.

103 See Beit-Arié 1981, 41-49, and in particular p. 47: 'Paper quires adhere to the same local practice [which is to say the technique used for parchment] in the Orient [5 bifolia] and Ashkenaz [4 bifolia], while they show a variety of compositions in Sefarad, Italy and Byzantium: 4-10 and 12 sheets in Sefarad, 5-10 and 12 sheets in Italy, 4-8 sheets in Byzantium'.

104 See Orsatti 1993, 307-308.

105 See Orsatti 1993, 312-313.

106 See Beit-Arié 1981, 44 and 48.

107 Irigoin offers this explanation for the Greek context too. See Irigoin 1998, 12. 
s'explique pas par le fait qu'on a ajouté deux bifolia aux quinions et sénions de papiers des cahiers normaux' ${ }^{108}$ In fact, this hypothesis is not applicable to the senion: 'pour les sénions, il est plus difficile de chosir une hypothèse parmi toutes celles possibles'. ${ }^{109}$ Another possible hypothesis could be that the aim was to create a sort of 'reinforced' senion, that is to say a quaternion made from paper, but protected on the outside and inside by a bifolium made from parchment. ${ }^{110}$

\subsection{Quiring and format}

In this section, only paper codices will be examined, since any study of the formats of parchment codices in the absence of an opportunity to conduct a hands-on examination of such material would be rather pointless. ${ }^{111}$

We have already ascertained that there was a preference for thicker quires where paper was concerned. Now we propose to investigate the nature of the relationship between quire typology and format, by which we mean the type of folding a sheet underwent in order to form the bifolia used to make quires. With this aim in mind, we shall analyse paper manuscript production of the $15^{\text {th112 }}$ century in its entirety by subdividing it into two distinct sub-groups: in-quarto and in-octavo codices on the one hand, and in-folio and large in-folio ${ }^{113}$ codices on the other.

Based on an examination of the data relating to European production considered overall, it emerges that the rate of diffusion of senions is the same whether it be for in-folio or large in-folio formats, and likewise for in-quarto and

108 Bianchi et al. 1994. Here, it should be pointed out that the same sort of hypothesis has been proposed in relation to Hebrew manuscripts: 'Tout se passe donc come si l'octonion mixte était un sénion de papier auquel on ajoute deux bifolia de parchemin' (278).

109 Bianchi et al. 1994, 279.

110 In the case of a single bifolium of parchment it could just as easily be postulated that one is dealing with a reinforced paper quinion.

111 Concerning the particular set of problems encountered in relation to the formats of parchment manuscripts, see Bischoff / Maniaci 1995, passim.

112 In our sample, the output from the first part of the $14^{\text {th }}$ century is almost irrelevant.

113 The definition of the terms in-folio and large in-folio in this instance serves a purely functional purpose. In fact, the two subdivisions were arrived at based on the height and width of codices. The first group includes all manuscripts attaining a maximum height of $340 \mathrm{mmm}$ and a maximum width of $240 \mathrm{~mm}$, whilst the second group includes all manuscripts of larger size, i.e. of a size $(\mathrm{H}+\mathrm{W})$ exceeding $560 \mathrm{~mm}$. 
in-octavo ${ }^{114}(52.3 \%)$ formats. The quinion, on the other hand, despite being well represented among the small formats (approximately 25\%), certainly proves to be more common in the larger ones (37\%). The quaternion, as we have already seen, does not appear to be a quire structure particularly well-suited to paperin the Latin context, at least. Indeed, in the in-quarto and in-octavo formats, it is adopted in $12.5 \%$ of production, whilst in the in-folio or large in-folio formats its rate of occurrence declines to just $3.2 \%$. In both groups a certain percentage of codices are composed of either octonions or thick and irregular quires, which are indicated by -1 (see Tab. 27 and 28).

$14^{\text {th }}$ and $15^{\text {th }}$ centuries. In-quarto and in-octavo. First / second half (tab. 27)

\begin{tabular}{|c|c|c|c|c|c|c|c|c|c|}
\hline \multirow{2}{*}{$\begin{array}{l}\text { Predom. } \\
\text { quiring }\end{array}$} & \multicolumn{3}{|c|}{$14^{\text {th }}$ century } & \multicolumn{4}{|c|}{$15^{\text {th }}$ century } & \multirow{2}{*}{$\begin{array}{l}\text { Total } \\
14^{\text {th }} \text { and } 15^{\text {th }}\end{array}$} & \multirow[b]{2}{*}{$\%$} \\
\hline & 1st half & 2nd half & Total & 1st half & 2nd half & $15^{\text {th }}$ & Total & & \\
\hline $1^{-1}$ & $1^{0}$ & $1^{0}$ & $1^{0}$ & $1^{0}$ & 6 & 10 & 16 & $1^{6}$ & 2.2 \\
\hline |'II & $1^{0}$ & $1^{0}$ & $1^{0}$ & $\left.\right|^{1}$ & $\left.\right|^{1}$ & $1^{0}$ & $1^{2}$ & $1^{2}$ & 0.7 \\
\hline IV & $1^{0}$ & $1^{2}$ & $1^{2}$ & 9 & 24 & $1^{0}$ & $1^{33}$ & $1^{35}$ & | 12.5 \\
\hline , V & $1^{0}$ & $1^{6}$ & $1^{6}$ & 8 & $1^{54}$ & $1^{2}$ & $1^{64}$ & $1^{70}$ & 25.1 \\
\hline , VI & $\left.\right|^{1}$ & $1^{7}$ & $1^{8}$ & 25 & |112 & $\left.\right|^{1}$ & 138 & |146 & |52.3 \\
\hline |VII & $1^{0}$ & $1^{0}$ & $1^{0}$ & $T^{2}$ & $a^{3}$ & +2 & $1^{1}$ & 1 & 0.4 \\
\hline | VIII & $1^{0}$ & $1^{0}$ & $1^{0}$ & $1^{3}$ & 9 & i) & 10 & -10 & 14.7 \\
\hline${ }_{1}^{x}$ & $1^{0}$ & 1 & $\left.\right|^{1}$ & $\left.\right|^{1}$ & $i^{2}$ & $1^{0}$ & $(\sqrt[5]{3}$ & $4^{3}$ & 1.4 \\
\hline${ }_{1} \mathrm{XII}$ & $1^{0}$ & $1^{0}$ & $1^{0}$ & $\left.\right|^{1}$ & $i^{2}$ & $1^{0}$ & $i^{2}$ & $1^{2}$ & 0.7 \\
\hline Total & $\left.\right|^{1}$ & 16 & 17 & $1^{48}$ & 210 & $1^{4}$ & 262 & |279 & |00 \\
\hline
\end{tabular}

Tab. 27: $14^{\text {th }}$ and $15^{\text {th }}$ centuries. In-quarto and in-octavo. First / second half

114 We shall be adopting the following abbreviations: in-folio = in-f; large in-folio = lf, inquarto $=$ in $4^{\circ}$, in-octavo $=$ in $8^{\circ}$. 
$14^{\text {th }}$ and $15^{\text {th }}$ centuries. In-folio and large in-folio. First / second half

(tab. 28)

\begin{tabular}{|c|c|c|c|c|c|c|c|c|c|}
\hline \multirow[b]{2}{*}{$\begin{array}{l}\text { Predom. } \\
\text { quiring }\end{array}$} & \multicolumn{3}{|c|}{$14^{\text {th }}$ century } & \multicolumn{4}{|c|}{$15^{\text {th }}$ century } & \multirow{2}{*}{$\begin{array}{l}\text { Total } \\
14^{\text {th }} \text { and } 15^{\text {th }}\end{array}$} & \multirow[b]{2}{*}{$\%$} \\
\hline & 1st half & 2nd half & Total & 1st half & 2nd half & $15^{\text {th } *}$ & Total & & \\
\hline$\left.\right|^{-1}$ & $1^{0}$ & $1^{2}$ & $1^{2}$ & $1^{0}$ & $1^{5}$ & $\left.\right|^{0}$ & $1^{5}$ & $1^{7}$ & 1.6 \\
\hline |'III & $1^{0}$ & $\left.\right|^{1}$ & $\left.\right|^{1}$ & $1^{0}$ & $1^{0}$ & $1^{0}$ & 10 & $\left.\right|^{1}$ & $\left.\right|^{0.2}$ \\
\hline IV & $1^{0}$ & $1^{3}$ & $1^{3}$ & $1^{3}$ & 8 & $1^{0}$ & $\left.\right|^{11}$ & $\left.\right|^{14}$ & |3.2 \\
\hline , v & $1^{0}$ & 12 & 12 & $1^{57}$ & |92 & $\left.\right|^{1}$ & 150 & 162 & $1^{37}$ \\
\hline ।VI & $1^{0}$ & |20 & $1^{20}$ & $1^{64}$ & 144 | & $\left.\right|^{1}$ & |209 & |229 & $\left.\right|^{52.3}$ \\
\hline ।VII & $।^{1}$ & $1^{0}$ & $।^{1}$ & $।^{1}$ & $1^{3}$ & $1^{0}$ & $1^{4}$ & $1^{5}$ & $\left.\right|^{1.1}$ \\
\hline | VIII & $\left.\right|^{1}$ & 10 & $\left.\right|^{1}$ & $1^{6}$ & $\left.\right|^{7}$ & $1^{0}$ & $\left.\right|^{13}$ & |14 & $\left.\right|^{3.2}$ \\
\hline$\left.\right|^{1 X}$ & $1^{0}$ & $\left.\right|^{1}$ & $\left.\right|^{1}$ & $1^{0}$ & $1^{0}$ & $1^{0}$ & $1^{0}$ & $\left.\right|^{1}$ & $\left.\right|^{0.2}$ \\
\hline${ }_{1}^{x}$ & $1^{0}$ & $1^{2}$ & $1^{2}$ & $1^{0}$ & $1^{0}$ & $1^{0}$ & $1^{0}$ & $1^{2}$ & 0.5 \\
\hline |XII & $1^{0}$ & 10 & $1^{0}$ & $1^{0}$ & $1^{3}$ & $1^{0}$ & $1^{3}$ & $1^{3}$ & | 0.7 \\
\hline Total & $1^{2}$ & $1^{41}$ & $1^{43}$ & |131 & $\left.\right|^{262}$ & $1^{2}$ & |395 & 1438 & 100 ן \\
\hline
\end{tabular}

Tab. 28: $14^{\text {th }}$ and $15^{\text {th }}$ centuries. In-folio and large in-folio. First / second half

At this point we should verify the way in which production rates are distributed in each individual country, ${ }^{115}$ since in the case of the support (for example) we discovered how the choice of a certain kind of quire does not depend solely, broadly speaking, on the choice of material (paper or parchment), but also on its use in different locations. ${ }^{116}$

In French production, the senion proves to be by far the most frequently used quire in both small and large formats (62\% and 65\%, respectively), although the latter's rate of diffusion is slightly higher. Conversely, the percentage of quinions is striking. Evidently these are seldom used in the smaller formats (3\%), but are well represented in larger formats, where they account for $19 \%$ of production. With respect to quaternions, precisely the opposite situation emerges: these are seen in $20 \%$ of the production of small format volumes,

115 In particular, French, German and Italian output will be analysed, given that the number of English paper codices is insufficient for the purposes of a statistical analysis.

116 Italian paper codex production mainly employed the quinion (as it did in parchment production as well), whereas in the rest of Europe the preference was for senions. 
whereas they play a fairly insignificant role in the production of in-folio and large in-folio format ones (3\%). Thick and irregular quires prove to be more frequent in the small formats than in the large ones, ${ }^{117}$ whilst the codices composed of octonions are seen in both types of production, even if they appear to be adopted more often in the larger in-folio and large in-folio formats (see Charts 5 and 6).

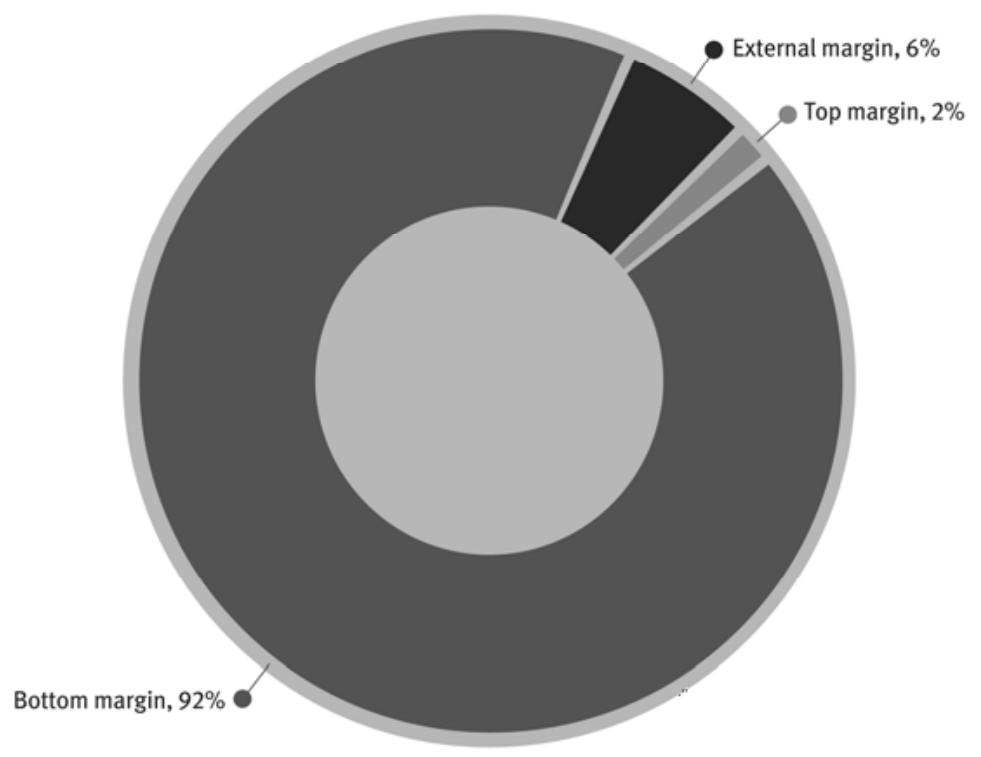

Chart 5: France, in-quarto and in-octavo (total number of codices: 31 )

117 Clearly, among the smaller formats there is a larger percentage of codices of not particularly high quality. 


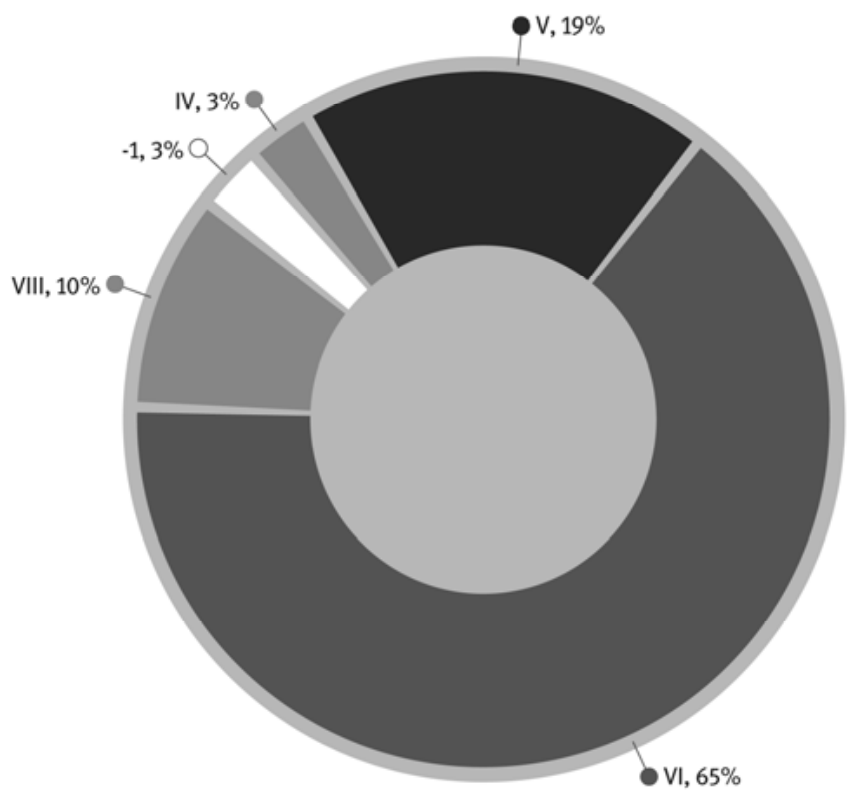

Chart 6: France, in-folio and large in-folio (total number of codices: 31)

To account for a distribution of this kind of the various types of quire, one could hypothesise that quires composed of an even number of bifolia were used to assemble small format codices, given that the quinion was seldom used in inquarto and in-octavo volumes, whilst it is in precisely these volumes that quaternions appear. A possible explanation for a choice of this kind may lie in the way in which in-quarto volumes were fabricated. In them, if the quires had been made from an odd number of bifolia-quinions, for example-it would have been necessary to cut a sheet of paper in two (so as to obtain a fifth bifolium), a step that would have required more time and effort than would be necessary if the quires were formed by carrying out an even number of folds. ${ }^{118}$

In small format volumes of Italian origin, the quinion-which was used in the vast majority of production, both parchment and paper-proves to be the preferred option, even if the quaternion and senion reach levels of diffusion equating to $14 \%$ and $15 \%$, respectively. On balance, then, 'even numbered'

118 Bozzolo / Ornato 1980, 145-147. 
quires are seen in $38 \%$ of the total production of small format volumes. Moreover, the effect of thicker quires composed of seven bifolia or more should not be underestimated, since it amounts to more than $10 \%{ }^{119}$ overall (see Chart 7 ).

\section{Italy, in-quarto and in-octavo (total number of codices: 101) $\quad$ (ch. 7)}

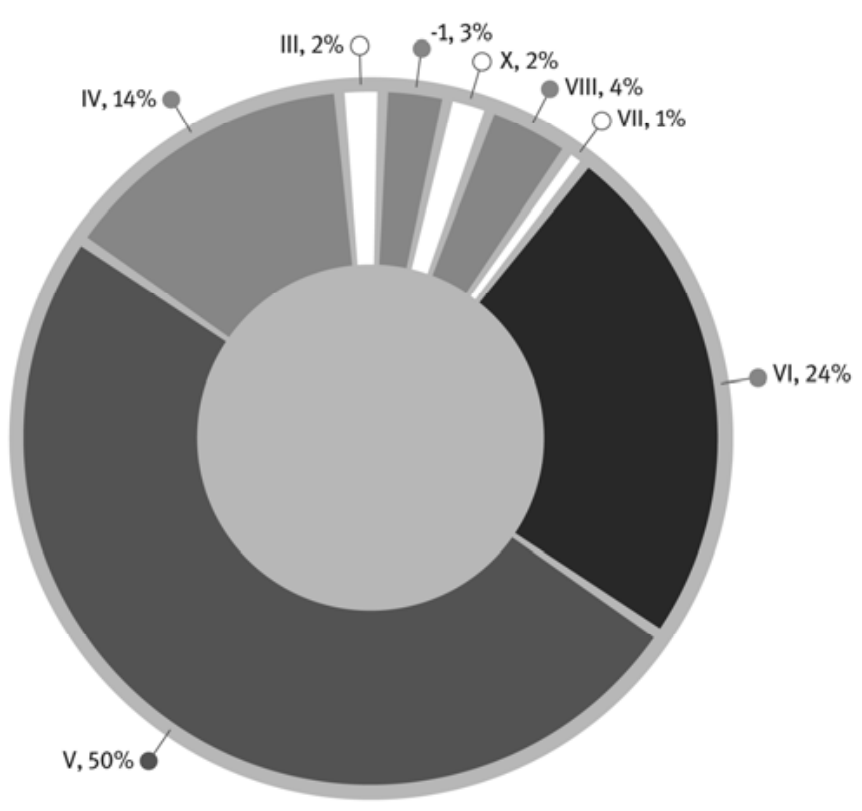

Chart 7: Italy, in-quarto and in-octavo (total number of codices: 101)

Conversely, large format codices present an entirely different kind of distribution: above all, quinions prove to be much more widely diffused, accounting for $68 \%$ of the total production (i.e. $18 \%$ more than in small format manuscripts), whilst the use of quaternions decreases to the point where it just scrapes $2 \%$. On the other hand, senions show a more or less stable distribution, amounting to $21 \%$ of the overall sample. The presence of codices made from quires composed of eight bifolia remains steady at $4 \%$. Septenions reach a level of $2 \%$, whilst the number of thicker quires ${ }^{120}$ decreases to a rate of $3 \%$ (see Chart 8 ).

119 The only codices composed of octonions are present at a rate of $4 \%$.

120 Quires composed of nine, ten and twelve bifolia. 


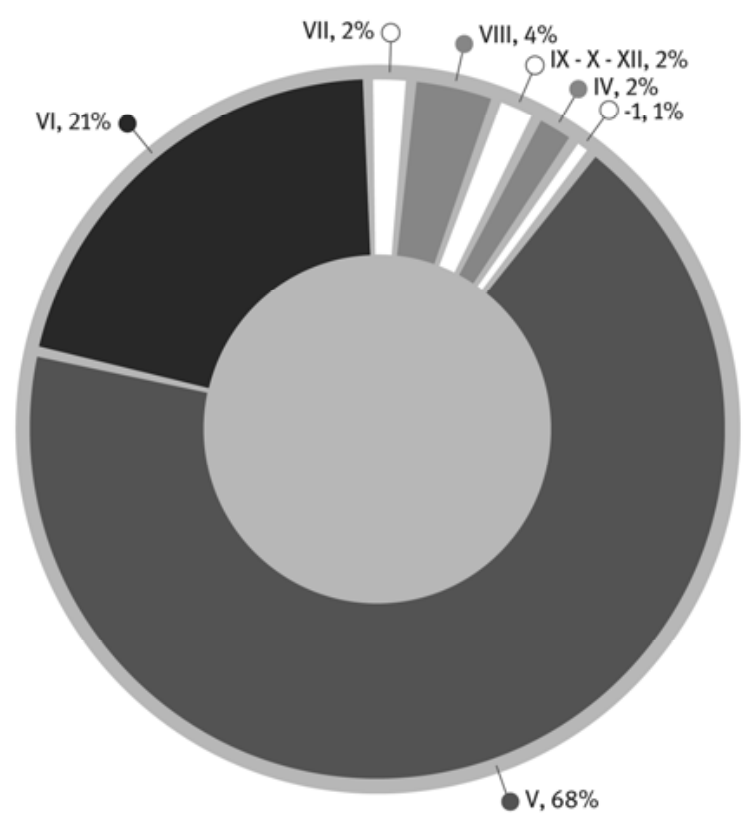

Chart 8: Italy, in-folio and large in-folio (total number of codices: 171)

Therefore in Italian production, too, one sees a certain tendency to use quires composed of an even number of bifolia in small format volumes, even though the quinion remains the preferred quire for the making of in-quarto and inoctavo books, where it still achieves a usage level of 50\%.

Large format volumes could be further subdivided to distinguish between in-folio and large in-folio formats in order to obtain a more accurate picture of the distribution of quires, above all with respect to quinions. In fact, it emerges that the quinion, notwithstanding its frequency of use in in-folio volumes (in the production of which they reach a level of diffusion of almost $61 \%$ ), appears to be by far the most favoured structure in the large in-folio volumes, to the extent that they comfortably achieve a diffusion rate of $80 \%$ (see Tab. 29). Here, it might be helpful to point out that in our sample 46 out of 55 large in-folio volumes composed of quinions are juridical manuscripts. 
Italy, in-folio and large in-folio. 15th century. First / second half

(tab. 29)

\begin{tabular}{|c|c|c|c|c|c|}
\hline \multirow[b]{2}{*}{ In-folio } & \multicolumn{3}{|c|}{ Predominant quiring } & \multicolumn{2}{|c|}{ Total $15^{\text {th }}$ century } \\
\hline & & 1st half & 2nd half & & $\%$ \\
\hline & $1^{-1}$ & $1^{0}$ & $1^{2}$ & $1^{2}$ & $1^{2.2}$ \\
\hline & IV & $\left.\right|^{1}$ & $1^{2}$ & $1^{3}$ & |3.4 \\
\hline & ।V & $\left.\right|^{14}$ & 140 & $1^{54}$ & , 60.7 \\
\hline & , $\mathrm{Vl}$ & $1^{7}$ & $\left.\right|^{13}$ & $1^{20}$ & $1^{22.5}$ \\
\hline & ।VII & $\left.\right|^{1}$ & $\left.\right|^{1}$ & $1^{2}$ & $1^{2.2}$ \\
\hline & , VIIII & $1^{3}$ & $1^{4}$ & $1^{7}$ & 17.9 \\
\hline & IXII & $1^{0}$ & $\left.\right|^{1}$ & $\left.\right|^{1}$ & |1.1 \\
\hline Total & & 26 & 63 & | 89 & 100 \\
\hline \multicolumn{6}{|c|}{ Large in-folio } \\
\hline & ।V & | 31 & $1^{24}$ & $1^{55}$ & |83.3 \\
\hline & , $\mathrm{Vl}$ & 9 & $1^{2}$ & $\left.\right|^{11}$ & | 16.7 \\
\hline Total & & 40 & 26 & , 66 & 100 \\
\hline
\end{tabular}

Tab. 29: Italy, in-folio and large in-folio, $15^{\text {th }}$ century. First / second half

In Germany, paper codices prove to be mainly composed of senions; indeed, this is true as much for the smaller formats, where they achieve a level of diffusion of $88 \%$, as for the larger ones, where they account for some $84 \%$ of the total production. The share of codices formed from quaternions is the same in both groups (2\%), as is also-roughly speaking-that of quinions, where it amounts to $10 \%$ in small format volumes and $11 \%$ in large ones (see Charts 9 and 10). In the German area, then, based on what can be inferred from our analysis of these data, there appears to be no difference in the manufacturing strategies adopted for both small and large format volumes. 


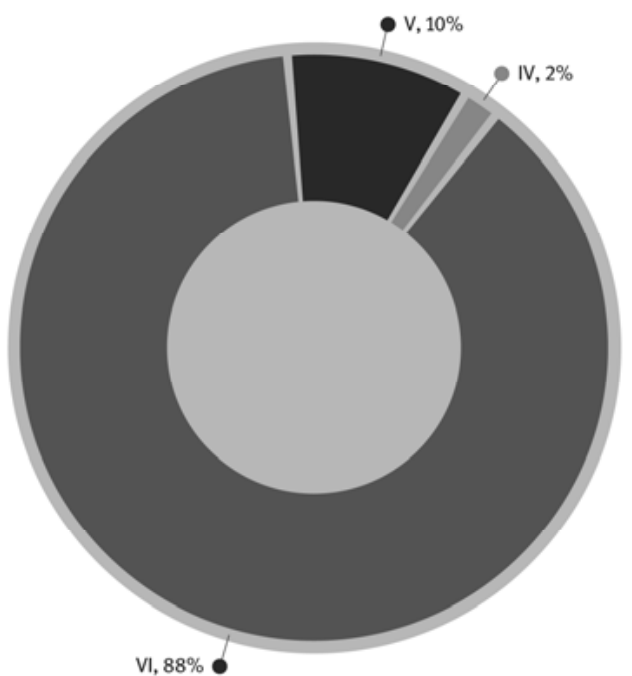

Chart 9: Germany, in-quarto and in-octavo (total number of codices: 83)

Germany, in-folio and large in-folio (total number of codices: 153) (ch. 10)

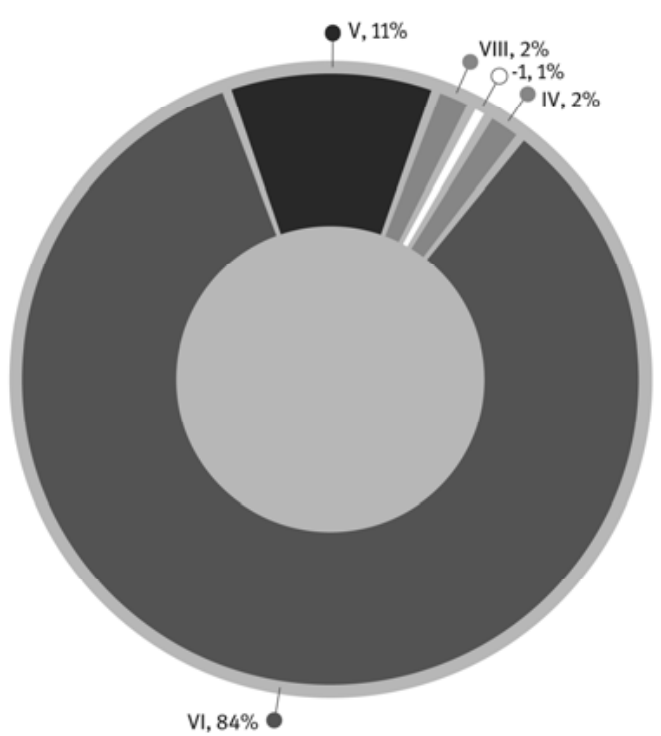

Chart 10: Germany, in-folio and large in-folio (total number of codices: 153) 


\subsection{Quiring and textual typology}

In order to highlight a possible link between textual typology and quiring we considered it practical-in the first phase, at least-to limit the investigation to the $13^{\text {th }}$ and $14^{\text {th }}$ centuries, which is to say the period when the widespread use of the quaternion declined and left the field open to other types of quire, including the senion and quinion, the latter above all in Italy.

The task of illustrating the relationship between textual typology and quiring is a rather complex one, given that the subdivision of textual types is not evenly distributed within one and the same country, and even less so among different countries. ${ }^{121}$ Furthermore, despite limiting our analysis to specific national contexts, ${ }^{122}$ the presence of different textual types varies considerably in relation to the time intervals examined. ${ }^{123}$ It is therefore obvious that in a situation where such disparate data have to be analysed some problems will arise, even if within the context of each individual nation some clear tendencies have emerged. Here, it seems worthwhile to shed some light on them. ${ }^{124}$

\subsubsection{England}

In England in the first half of the $13^{\text {th }}$ century one already finds a certain percentage of codices composed of senions. However, these do not seem to be linked to any specific textual type, apart from Bibles, which appear to be composed of senions in a just under half of all instances ${ }^{125}$ Starting from the second half of the $13^{\text {th }}$ century, senions are seen throughout English production, to the extent that they were used in codices that acted as vehicles for all textual types. In theological texts, senions account for $84 \%{ }^{126}$ of the total sample, whilst in

121 This happens not only because each country may have favoured different disciplinesindeed, it is well known that at that time France produced a large amount of theological manuscripts, while Italy predominated in other sectors, including juridical studies-but also on account of the limitations of the sample which, as we have pointed out, was assembled using catalogues.

122 With the passage of time, needs changed in each country and therefore production types changed as well. Furthermore, our sample has intrinsic limitations, as we have pointed out previously.

$12313^{\text {th }} \cdot 1,13^{\text {th }} \cdot 2,14^{\text {th }} \cdot 1,14^{\text {th }} \cdot 2$.

124 The subdivision of codices according to textual typology and quiring was deemed impractical for Germany because the total number of representative items in the sample for the $13^{\text {th }}$ and $14^{\text {th }}$ centuries was not sufficient to permit the creation of subdivisions.

125 Out of a total of 11 occurrences, 5 are composed of senions.

126 Out of a total of 25 occurrences, 2 are composed of quaternions, 2 of octonions, and 21 of senions. 
liturgical and patristic texts ${ }^{127}$ they are present in three quarters of the production. The same is true of sermons and histories. ${ }^{128}$ As for Bibles, senions account for almost half of the output, whilst in the other half more substantial quires of eight or more bifolia were employed. ${ }^{129}$ Needless to say, our observations regarding the various textual types do not all have the same value, given that in some instances we can count on plentiful numbers-theological, liturgical, patristic and biblical texts-whereas in other instances, such as collections of sermons and histories, a rather restricted sample meant that it was only possible identify some general indications.

The first half of the $14^{\text {th }}$ century is marked by production strategies that see the revival of the quaternion (observed in $34 \%$ of the total sample), although the senion remains the most commonly used quire. University texts-i.e. theological and philosophical works, and sermons-are still composed entirely of senions, as are juridical texts. ${ }^{130}$

With respect to quaternions, ${ }^{131}$ these appear most frequently in codices containing the Statuta Angliae, ${ }^{132}$ of broadly speaking, though not wholly, juridical content, and in liturgical volumes, which are almost exclusively assembled from quaternions.

In the second half of the $14^{\text {th }}$ century, the quaternion is by now favoured in the bulk of production (56.5\% of the total), although the senion is still seen above all in specific types of manuscript. In fact, it is quite noticeable how senions continue to represent the quire of choice $(62.5 \%)$ in theological texts. This is also the case with the collections of sermons (57.7\%). In addition, for this period the only two philosophical codices in the sample are composed of senions.

The remainder of the output is predominantly formed from quaternions, which in liturgical volumes amount to $71 \%$ of the total production. Quaternions

127 In the liturgical volumes, out of a total of 16 manuscripts, 12 are composed of senions, whereas in the patristic books 9 out of 12 are composed of senions.

128 The total number of occurrences for each of these two groups is under ten units.

129 Out of a total of 38 occurrences, 18 are composed of senions and 18 of quires assembled from eight bifolia and above.

130 In this last instance, the number of items in the sample is particularly low (only 4 occurrences), which furthermore are all composed of senions.

131 Out of a total of 24 occurrences, 14 are composed of quaternions, 9 of senions, and 1 of quinions.

132 These codices are indicated using the label giu2. Concerning the labels that indicate the various types of textual typology, see Appendix I, Surveying Protocol, in the sub-section 'Textual typology'. 
are also represented in $59 \%$ of sacred texts, $71 \%$ of codices containing statutes and related material, $51 \%$ of histories, and $66 \%$ of glossed gospels.

Bibles as a textual typology merit a separate comment, even if very few of them are present in the sample. ${ }^{133}$ These seem to exhibit a distinct change in their physical structure: indeed, some $90 \%$ of them are formed from quaternions. The change of manufacturing strategy with respect to quiring probably reflects a production context and functionality which no longer targeted the single user, but instead a community. ${ }^{134}$

\subsubsection{France}

In the first half of the $13^{\text {th }}$ century French manuscript production is still concentrated on the quaternion, even if a few examples of codices composed of senions have already begun to appear among the theological and juridical works, and Bibles.

Starting in the second half of the century, production of volumes composed of senions, as we have already seen, accounts for almost two fifths of the total: in particular, theological (71.4\%), philosophical (76\%), and almost half of sermon collections are structured in senions. Volumes of a juridical nature are by preference fabricated using senions, although there is no lack of examples assembled from quinions and quaternions.

The book of the Bible, in particular, is assembled using decidedly thick structures, including quires of six, eight and ten, but most of all twelve bifolia. ${ }^{135}$

On the other hand, the quaternion is the preferred quire for liturgical codices, and those containing sacred texts, texts on medicine, the classics and history, although in the first four typologies other kinds of quiring can be observed. ${ }^{136}$

A sample of sufficient size was not available for the first half of the $14^{\text {th }}$ century. However, in our opinion it is still possible to put forward some general observations. The manuscripts originating from universities present with a structure that had already been trialled in the previous century-in fact, the theological volumes are composed of senions in $75 \%$ of cases. In the codices containing sacred texts, qua-

133 Out of a total of 9 occurrences, 8 are composed of quaternions, and 1 of senions.

134 Bozzolo / Ornato 1980, 265.

135 We will return to the Bibles later on in this contribution.

136 Liturgical works: out of a total of 13 occurrences, 8 are composed of quaternions, 1 of quinions, and 4 of senions; Sacred literature: out of a total of 12 occurrences, 7 are composed of quaternions, 2 of senions, and 3 of octonions; Medical texts: out of a total of 8 occurrences, 5 are composed of quaternions, 1 of quinions, and 2 of senions; Classical texts: out of a total of 7 occurrences, 5 are composed of quaternions, 1 of quinions, and 2 of senions. 
ternions and senions are used in equal measure, whereas the production of juridical codices seems always to favour the use of senions.

The use of quaternions in more than half of the output is taken up again in the second half of the century. This is the case, above all, in liturgical texts, where this type of quire becomes practically invariable $\left(90 \%\right.$ of the total) ${ }^{137}$. Sacred texts are produced in equal measure in quaternions and senions, as in the previous half-century. Needless to say, a certain percentage of manuscripts composed of senions survive in various other textual typologies, such as, for example, the classics, but to a greater degree only in juridical codices, which are composed of senions in $70 \%$ of cases.

Therefore, both in France and in England the senion is mainly linked to the printed university book, where it endures even when book manufacturing strategies change at a more generalised level. Other types of codices, such as liturgical ones in England, adopted the senion only for a limited period of time, which more or less coincides with the period of maximum diffusion, and subsequently reverted to the traditional structure, namely the quaternion.

\subsubsection{Italy}

In the first half of the $13^{\text {th }}$ century the population of our sample is not particularly representative. Nevertheless, as we have already stressed, a clear preference for the quaternion in Italian production is plain to see.

Starting in the second half of the century, we meet with quaternions and quinions as much as with senions, with the latter not being linked to a specific genre of codex, apart from Bibles, in which they reign supreme. The same is true of quaternions which, apart from in liturgical codices where, broadly speaking, they prove to be the predominant quire type, appear in almost all textual typologies. Quinions, on the other hand, despite being in a minority in our sample in relation to the aforementioned other two quire types, appear to be the preferred solution for the structuring of juridical texts, to the extent that they appear in eight out of twelve codices (66.6\% of the total). ${ }^{138}$

In the first half of the $14^{\text {th }}$ century the number of instances of codices composed of quaternions, quinions and senions is almost the same. The three types of quire are distributed more or less equally among the various textual typologies, with the exception of juridical codices, which are predominantly com-

137 Out of a total of 20 occurrences, 18 are composed of quaternions and 2 of senions.

138 We can also report 2 codices composed of quaternions and 2 of senions. 
posed of quinions (7 examples in 8), and the small number of theological volumes, which are all composed of senions.

The second half of the century is set against a contextual backdrop in which the quinion is fully established. Once again, the juridical codex in particular is fully in tune with this type of quire: indeed, 18 volumes of 22 (about 82\%) present with this structure. In codices containing profane texts, and in theological and liturgical volumes, the quinion predominates, and indeed plays, from this time onwards, a fundamental role in manuscript production, both in parchment and in paper.

Quaternions, used in the production of all textual typologies, hold a subordinate position compared with quinions, apart from in books containing the classics, in which they are used to a greater extent.

In liturgical and theological codices, and in volumes of sacred and profane texts, one continues to find volumes composed of senions, even if this choice is not the preferred solution in any particular textual typology.

In Italian production, then, following a period of even distribution in the utilisation of the various types of quire, the quinion became the preferred structure in all textual typologies, with juridical codices leading the way, where they make their first strong appearance.

\subsubsection{Bibles}

In the early centuries of the Middle Ages up until and including the entire $12^{\text {th }}$ century, the Bible ${ }^{139}$ represented the embodiment of the word of God and functioned as a symbol of the spiritual identity of a monastery, a bishop's office, or the religious duties of a sovereign. It therefore took on a public meaning which was reflected in its physical characteristics-majestic, multi-volume, lavishly illustrated. By contrast, in the $13^{\text {th }}$ century a new type of Bible appeared-of small format, with the text of the Old and New Testaments contained in one volume-that clearly signalled a new conception of the Bible, which by now had become a book intended for strictly personal use. ${ }^{140}$ This does not mean to say that large format

139 Here, we are not referring to a particular type of Bible, but rather to an ideal notion. See Light 1987, 276: 'Before the thirteenth century, the Bible, whether we are speaking of the great English and French twelfth-century romanesque Bibles, the Italian giant Bibles of the eleventh and twelfth centuries, the lavish Ottonian gospel books, or the ninth-century products of the scriptorium at Tours, was an impressive embodiment of the word of God [...]'.

140 Light 1987, passim. 
Bibles were no longer produced; on the contrary, at this time in northern France we find multi-volume large format Bibles, and in Italy large format single-volume Bibles. Among all the types of Bible produced in the $13^{\text {th }}$ century, the so-called 'pocket Bibles'141 are beyond doubt the most original, above all because they represent the change that occurred in the very conception of the Bible, which had previously been seen as a symbolic object laden with extra-textual significance but now became an object for personal use-a book for reading and for referring to specific passages in. The first Bibles of this type seem to emerge simultaneously in France and England in about 1230, and a few years later they spread to Italy and Spain. ${ }^{142}$ The hypothesis regarding the advent of pocket Bibles and, above all, their likely users, points towards universities, since the small format seems to fulfil the need of students and teachers to possess an easily transportable text. The same is true of mendicant monks, who also needed to have at their disposal an easily consultable and transportable sourcebook. ${ }^{143}$

This is not the appropriate place to fully explore a topic of this kind, which not only encompasses the physical materiality of the book-Bible object, but also the very concept it implies. Instead, what we wish to stress here is the extent to which the transformation of an intellectual representation-in this case, of the Bible-resulted in material changes in its 'vehicle', namely the book as an object. The most direct result of this new concept-if we leave to one side the novelty of the presentation of the sacred text in a single volume, which affects both large and small formats equally-is without doubt the so-called pocket Bible. The material characteristics of this product are well known to all: a single volume with a large number of leaves made from exceedingly thin parchment structured into particularly thick quires; minute script (textualis or Gothic bookhand); and a decorative apparatus that varies from volume to volume, and which sometimes was executed with extraordinary care.

This description-which clearly is not exhaustive-has the sole purpose of calling to the reader's mind the image that is most often associated with the concept of a pocket Bible. This typology accounts for some 54 witnesses $^{144}$ in our cor-

141 Not to be confused with 'Paris Bibles', in other words Bibles of a different format-ranging from pocket-sized to monumental-which reflect a very clear textual tradition that originated in Paris in around 1230 and spread throughout the rest of France and Europe. See Light 1994, passim.

142 Light 1987, 277.

143 Light 1987, 279.

144 The definition of the term 'pocket Bible' is subject to arbitrary interpretations, but in our case we are dealing only with Bibles defined as such based on the characteristics indicated by Light 1987, 278, which is to say not exceeding $200 \mathrm{~mm}$ in leaf height and $150 \mathrm{~mm}$ in written area height. 
pus. The volumes originate from various countries (see Tab. 30), and all present with rather thick quires:

$\begin{array}{lll}-\quad 5 \text { bifolia } & 1(1.8 \%) \\ -\quad 6 \text { bifolia } & 15(27.8) \\ -\quad 8 \text { bifolia } & 11(20.5 \%) \\ - & 10 \text { bifolia } & 9(16.7 \%) \\ - & 11 \text { bifolia } & 1(1.9 \%) \\ - & 12 \text { bifolia } & 17(31.4 \%)^{145}\end{array}$

\begin{tabular}{|c|c|c|c|c|c|c|}
\hline Pocket Bi & ibles & & & & & (tab. 30) \\
\hline Predom. quiring & England & France & Italy & Low Countries & German area & Total \\
\hline ¡v & $\left.\right|^{1}$ & $0^{0}$ & 10 & 10 & $1^{0}$ & $1^{1}$ \\
\hline ¡VI & 8 & $1^{2}$ & $1^{4}$ & $\left.\right|^{1}$ & $1^{0}$ & 15 \\
\hline ¡VIII & $1^{6}$ & 14 & $1^{0}$ & $1^{0}$ & $\left.\right|^{1}$ & $\left.\right|^{11}$ \\
\hline${ }_{1}^{x}$ & $1^{3}$ & $1^{6}$ & $1^{0}$ & 10 & $1^{0}$ & 9 \\
\hline $\mathrm{I}^{\mathrm{X}}$ & $1^{0}$ & $\left.\right|^{1}$ & $1^{0}$ & $1^{0}$ & $1^{0}$ & $1^{1}$ \\
\hline${ }_{\mid}^{x \|}$ & $1^{3}$ & $1^{14}$ & 10 & 10 & 10 & , 3 \\
\hline Total & 21 & 27 & $1^{4}$ & $\left.\right|^{1}$ & $1^{1}$ & $1^{564}$ \\
\hline
\end{tabular}

Tab. 30: Pocket Bibles

The Bible's new function meant that it had to be re-conceptualised from a material standpoint as well: the need to house both the Old and New Testaments in one small format volume calls for a series of well thought out choices being made. These choices concern the mise en texte and the mise en page, just as much as the support that hosts them. In fact, the parchment used had to be particularly thin in order to make it possible to contain the entire biblical text within a single volume.

In all likelihood, it was precisely the thinness of the parchment which, from a technical point of view, made the creation of this new type of Bible possible. ${ }^{146}$

145 These percentages are presented in Chart 11, in which rounded values are shown.

146 'Two technical innovations-extremely thin, almost translucent parchment, and a minute, very compact gothic book hand-opened the way for a Bible that was not only very small in 




Chart 11: Pocket Bibles

At the same time, the parchment's extreme thinness may account for the decision to assemble particularly thick quires, a choice which would assure a certain amount of robustness over time. We should not forget that for paper, too, similar hypotheses have been proposed: thicker quires could be related to materials-both paper and parchment-that were particularly thin, and which were considered less robust.

Naturally, thicker quires were also employed in larger format Bibles (see Tab. 31, which lists all the $13^{\text {th }}$-century Bibles present in our corpus). Indeed, Bibles contained within a single volume-be they of medium or large formatcalled for carefully considered solutions, both with respect to page construction and the organisation of the relevant support.

terms of the size of each page, but also one which was not cumbersomely thick when bound in one volume'. See Light 1987, 278. 
Bibles, $13^{\text {th }}$ century. First / second half

(tab. 31)

\begin{tabular}{|c|c|c|c|c|c|c|c|c|c|}
\hline \multirow{2}{*}{$\begin{array}{l}\text { Predom. } \\
\text { quiring }\end{array}$} & \multicolumn{3}{|l|}{ First half } & \multicolumn{5}{|c|}{ Second half } & \multirow[t]{2}{*}{ Total } \\
\hline & England & France & Total & England & France & Italy & German area & Total & \\
\hline IV & $1^{2}$ & $1^{0}$ & $1^{2}$ & $1^{1}$ & $\left.\right|^{1}$ & $1^{0}$ & $1^{0}$ & $1^{2}$ & $1^{4}$ \\
\hline , $v$ & $1^{4}$ & $1^{0}$ & $1^{4}$ & $1^{2}$ & $1^{0}$ & $1^{0}$ & $1^{0}$ & $1^{2}$ & $1^{6}$ \\
\hline , VI & $1^{5}$ & $1^{3}$ & 8 & $\left.\right|^{18}$ & $1^{6}$ & $1^{6}$ & $\left.\right|^{1}$ & | 31 & 39 \\
\hline |VIII & $1^{0}$ & $\left.\right|^{1}$ & $\left.\right|^{1}$ & $1^{9}$ & $1^{7}$ & $1^{0}$ & $\left.\right|^{1}$ & $\left.\right|^{17}$ & $\left.\right|^{18}$ \\
\hline${ }_{1} x$ & $1^{0}$ & 1 & 1 & $1^{4}$ & $1^{6}$ & $1^{0}$ & $1^{0}$ & $\left.\right|^{10}$ & $\left.\right|^{11}$ \\
\hline${ }_{1} \mathrm{XI}$ & $1^{0}$ & $1^{0}$ & 10 & $1^{0}$ & $\left.\right|^{1}$ & 10 & $1^{0}$ & $\left.\right|^{1}$ & $\left.\right|^{1}$ \\
\hline${ }_{1} \mathrm{XII}$ & $1^{0}$ & $1^{0}$ & $1^{0}$ & $1^{4}$ & 16 & $1^{0}$ & $1^{0}$ & $1^{20}$ & 20 \\
\hline Total & |11 & $1^{5}$ & $\left.\right|^{16}$ & $1^{38}$ & 37 & $1^{6}$ & $1^{2}$ & 83 & |99 \\
\hline
\end{tabular}

Tab. 31: Bibles, $13^{\text {th }}$ century. First / second half

The number of $14^{\text {th }}$-century Bibles in our corpus is distinctly low. Nevertheless, one can quite easily ascertain that the quaternion reclaimed its position as the predominant type of quire, ${ }^{147}$ thereby once again altering the concept of the Bible as a product, and therefore the manufacturing solutions associated with it.

\subsection{Quiring and layout}

It is well known that in the Latin context a correlation exists between the size of manuscripts ${ }^{148}$ and their proportions, ${ }^{149}$ in the sense that, as the centuries pass, one observes an attempt to rationalise codices so as to produce, roughly speaking, volumes of consistent proportions, irrespective of the number of folds the skin undergoes. ${ }^{150}$ The arrangement of the text on the page proves to be linked to the volume's size, insofar as in all eras layouts in one column are more com-

147 Out of a total of 13 occurrences, 9 are composed of quaternions, 1 of quinions, 2 of senions, and 1 of quires assembled from 12 bifolia.

148 Regarding the term 'size, see note 80.

149 The term 'proportion' refers to the width/height relationship.

150 For some hypotheses on how this correlation works, see Bozzolo / Ornato 1980, 253-261; Bianchi et al. 1993b, 386-390. 
mon in 'small' manuscripts, whereas layouts in two columns are more common in 'large' ones. ${ }^{151}$ Most likely, the correlation that exists between the size of codices and the layout of the text overshadows the relationship which unites the latter with the dimensions of the written area, and therefore the dimensions of the leaves themselves. ${ }^{152}$

Therefore, the proportion of the page is correlated to the layout of the text in either one or two columns, ${ }^{153}$ and the choice of one or the other solution seems to depend on the dimensions of the written area and line spacing. ${ }^{154}$ In particular, the adoption of a two-column layout is embraced more quickly as the line spacing decreases. Like line spacing, the type of script also exerts a certain influence over the speed with which the shift is made from one type of mise en page to the other. Clearly, legibility plays a fundamental role in this connection: in fact, the layout of the text in two columns makes it possible to preserve maximum usability without sacrificing the overall 'performance' of the page. ${ }^{155}$

We shall not concern ourselves here with the reason why one form of layout was chosen over another; rather, we shall try to determine whether a link exists between the layout of the text and quiring-in other words, whether or not a certain type of quire proves to be used more frequently for full-page layouts or two-column ones.

Also in carrying out this part of the investigation we shall examine the $13^{\text {th }}$ and $14^{\text {th }}$ centuries in relation to the production of England, France and Italy ${ }^{156}$ (we have already explained the reasons behind this choice vis-à-vis textual typologies). We should immediately make it clear that the data with respect to the $13^{\text {th }}$ and $14^{\text {th }}$ centuries will be placed in comparison with an added degree of caution, since they relate to unequal numbers of items in the sample and, above all, to different textual typologies-or at least ones which are present in different numbers. ${ }^{157}$

151 Here, we are referring to essentially high width/height values.

152 Bozzolo / Ornato 1980, 322.

153 Bozzolo / Ornato 1980, 326.

154 Bozzolo / Ornato 1980, 318-330.

155 Bozzolo et al. 1984, 215-221.

156 There are not enough $13^{\text {th }}$ - and $14^{\text {th }}$-century codices originating from Germany and the Low Countries in our sample to enable us to make further subdivisions.

157 Earlier on we ascertained that some textual typologies are linked to the use of specific quires, hence a strong presence of codices on certain subjects can affect the representativeness of the sample. 


\subsubsection{England}

Already in the first half of the $13^{\text {th }}$ century, for which the population of manuscripts structured in senions in our sample of codices is not very high, the link between this type of quire and the layout of the text in two columns seems to be clear, to the extent that $32 \%$ of the codices in question present with quires formed from six bifolia. On the other hand, the arrangement of bifolia into quaternions is the preferred solution for manuscripts laid out in a single column ( $70.4 \%$ of the total), in which the percentage of senions is very low. The quinion appears to be adopted for both single block and twocolumn layouts, although in the latter the percentage is higher (see Tab. 32). In the second half of the $13^{\text {th }}$ century the use of senions is very widespread. However, one notices a small difference which favours the two-column layout $(65 \%)$ over the full-page layout $(59.1 \%)$. Here, it must be remembered that the two-column layout, despite the fact that it was used in all periods, and from the $11^{\text {th }}$ century onwards took on an increasingly preponderant role, was adopted as a favoured technical solution starting, indeed, in the $13^{\text {th }}$ century. ${ }^{158}$ Full-page codices, even if they are in a clear minority in comparison to two-column manuscripts, and are chiefly quired in senions, are composed of quaternions in $27.3 \%$ of the sample. The two-column / senions association is mainly represented in the first half of the century, whereas the link between the full-page and quaternions seems rather strong in the second half of the $13^{\text {th }}$ century, when the use of senions is widespread (see Charts 12 and 13). A final observation concerns the thickest quires (i.e. quires containing eight, ten or twelve bifolia), which are consistently correlated to two-column layouts (see Tab. 32, and Chart 13). ${ }^{159}$

158 Concerning the spread of two-column layouts and what motivated their use, see Bozzolo / Ornato 1980, passim.

159 Often one is dealing with pocket Bibles, for which a two-column layout became necessary so as to render them legible. 


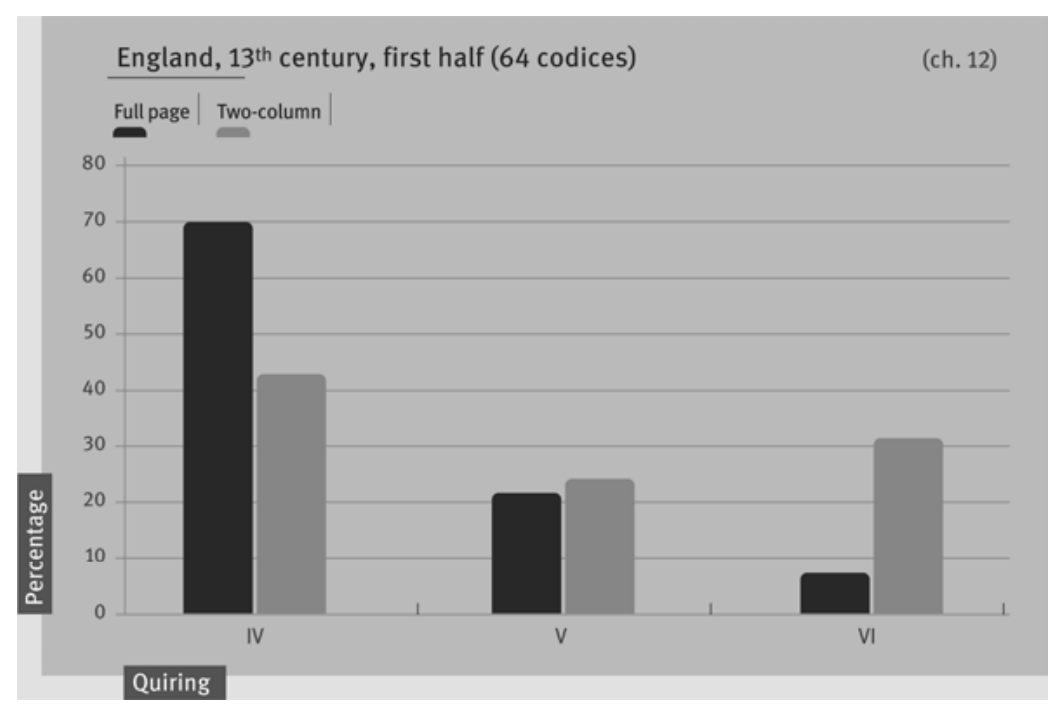

Chart 12: England, $13^{\text {th }}$ century, first half (64 codices)

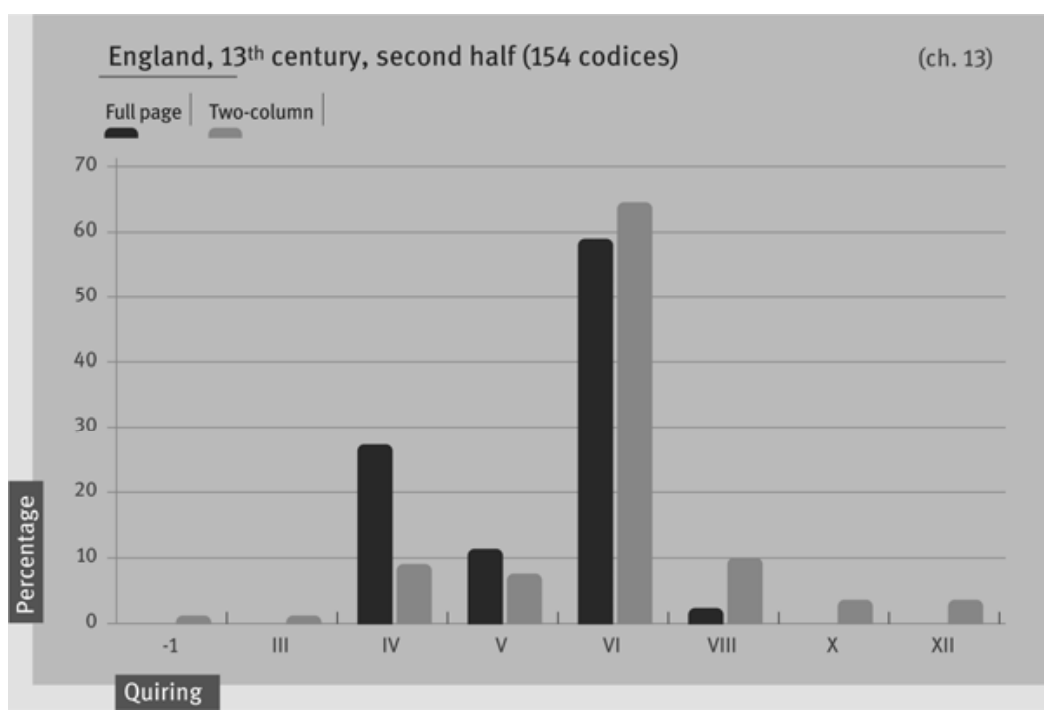

Chart 13: England, $13^{\text {th }}$ century, second half (154 codices) 


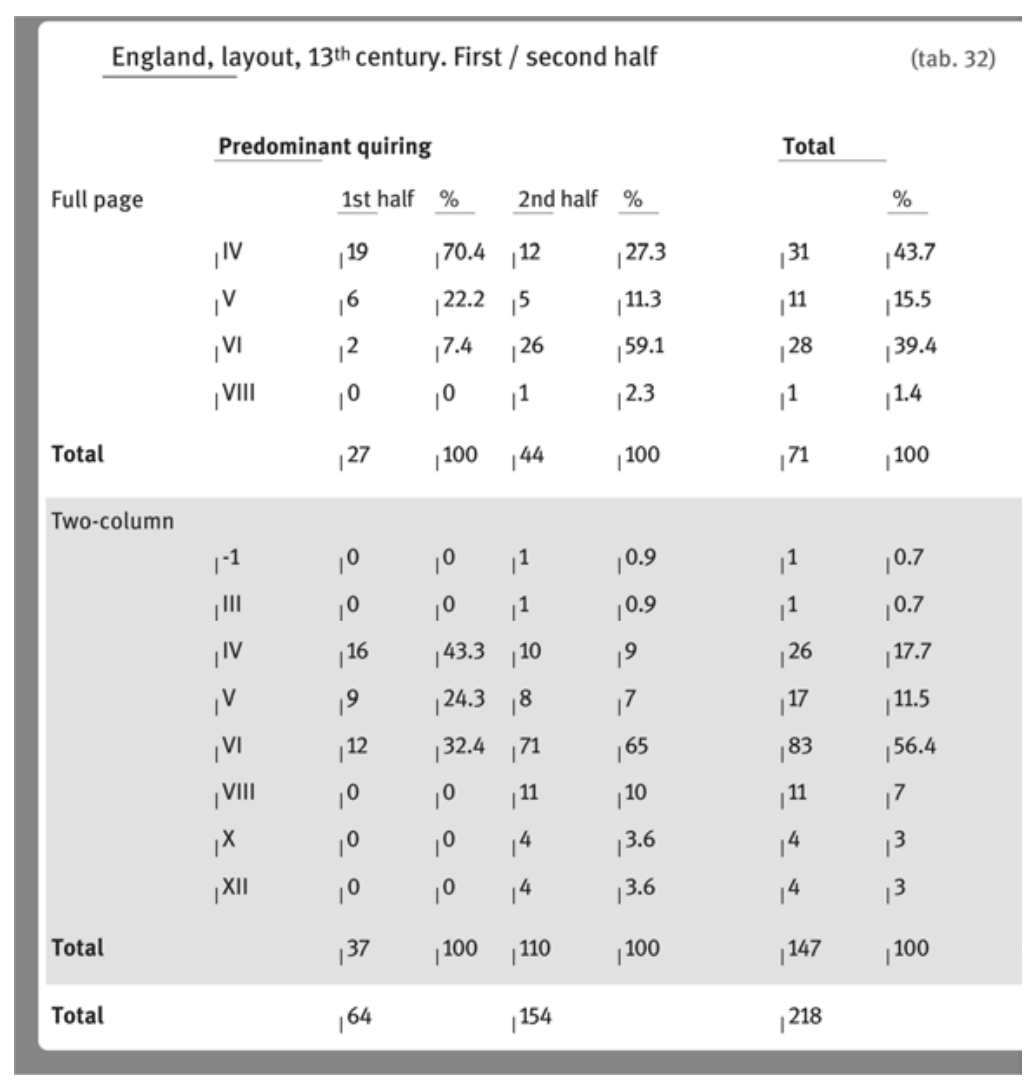

Tab. 32: England, layout, $13^{\text {th }}$ century. First / second half

During the first half of the $14^{\text {th }}$ century, even if full-page layouts can be associated as much with quaternions as with senions, the close link that exists between two-column layouts and quiring in senions (84\%) once again emerges very clearly (see Tab. 33 and Chart 14). The mechanism that governs the latter type of association is not readily identifiable. However, it seems fairly clear that in the case of full-page manuscripts-even if one cannot deny a preference for the quaternion-there is certainly more flexibility in the choice of the quiring structure. We already know that, starting in the second half of the $14^{\text {th }}$ century, a change took place in the manufacturing techniques used for manuscripts. This change re-focused attention on the quaternion, notwithstanding a certain tendency to associate the quaternion with full-page layouts and the senion with two-column ones, though in a less marked way than in the antecedent periods (see Tab. 33 and Chart 15). 
England, layout, $14^{\text {th }}$ century. First / second half

\section{Predominant quiring}

Full page

\begin{tabular}{|c|c|c|c|c|}
\hline & 1st half & $\%$ & 2nd half & $\%$ \\
\hline$\left.\right|^{-1}$ & $\left.\right|^{1}$ & 2.4 & $\left.\right|^{1}$ & 1.3 \\
\hline |'II & $1^{0}$ & $1^{0}$ & $\left.\right|^{1}$ & 1.3 \\
\hline IIV & $1^{20}$ & | 48.8 & $1^{49}$ & |62 \\
\hline ।V & $1^{2}$ & 14.9 & $1^{4}$ & $1^{5}$ \\
\hline الإ & | 18 & 143.9 & |24 & |30.4 \\
\hline
\end{tabular}

Total

। $41 \quad$ |100 ,79 |100

Two-column

II $^{-1}$
III $^{\mathrm{IV}}$
।VI $^{\mathrm{VIII}}$

Total

$\left.।^{0} \quad ।^{0} \quad ।^{1} \quad\right|^{1.4}$

$\left.\left.।^{0} \quad ।^{0} \quad\right|^{1} \quad\right|^{1.4}$

$\left.1^{4} \quad 1^{16} \quad\right|^{35}$

| 50.8

$1^{0} \quad 1^{2}$

$1^{3}$

$1^{42}$

| 1.4

, 0 | 1

| 25

, 100

169

| 100

| 148

, 66

214

Total

$1^{66}$ (tab. 33)

Total

$\begin{array}{ll}1^{2} & \frac{\%}{।^{1.7}} \\ 1^{1} & ।^{0.8} \\ 1^{69} & 1^{57.5} \\ 1^{6} & 1^{5} \\ 1^{42} & 1^{35}\end{array}$

| 120 | 100

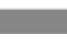

Tab. 33: England, layout, $14^{\text {th }}$ century. First / second half 


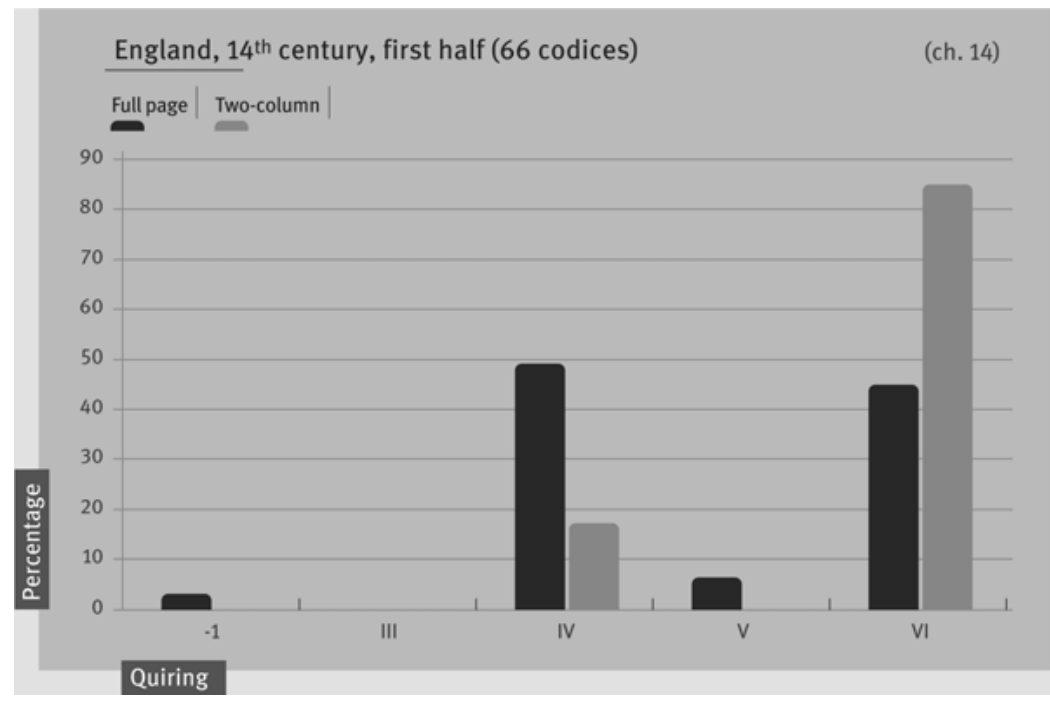

Chart 14: England,14 ${ }^{\text {th }}$ century, first half ( 66 codices)

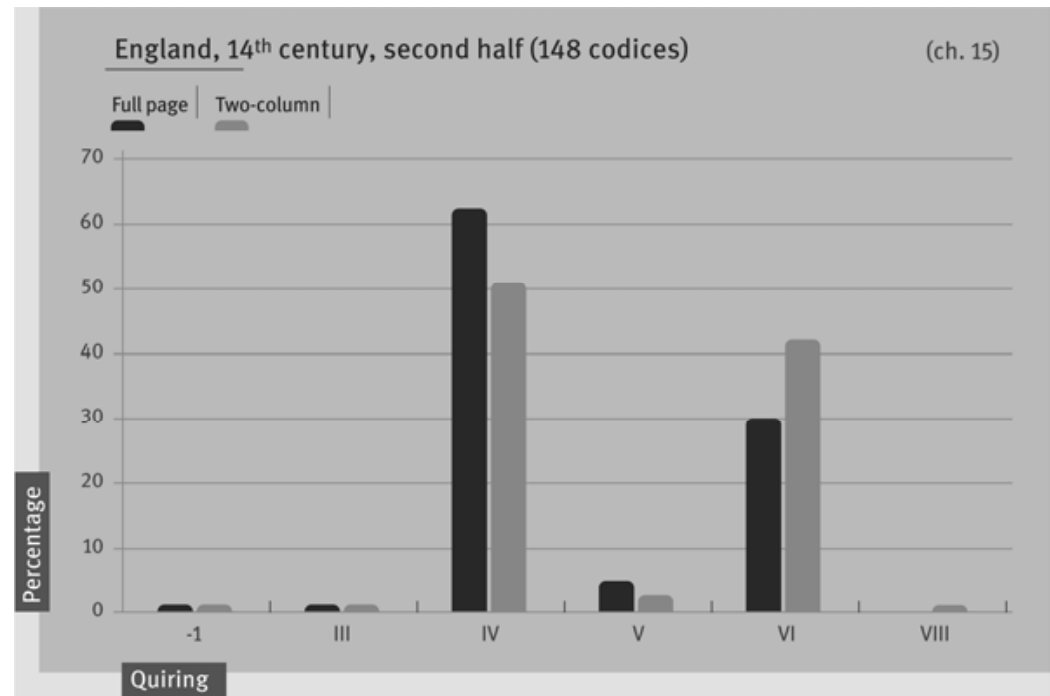

Chart 15: England, $14^{\text {th }}$ century, second half (148 codices) 


\subsubsection{France}

In the first half of the $13^{\text {th }}$ century French manuscript production is for the most part based on the quaternions, which are seen as much in full-page layouts as in two-column ones. However, we should not fail to point out that almost all the codices composed of senions, in addition to the small number composed of thicker quires, have two-column layouts. Starting from the second half of the $13^{\text {th }}$ century, layouts in two-columns became the norm and are associated with very thick quires composed of six, eight, ten or twelve bifolia, although some of the production is structured in quaternions (approximately 22\%). Pages laid out in one column are almost always seen in volumes composed of quaternions (71.4\%), apart from a few instances of senions and other types of quire (see Tab. 34 and Charts 16 and 17).

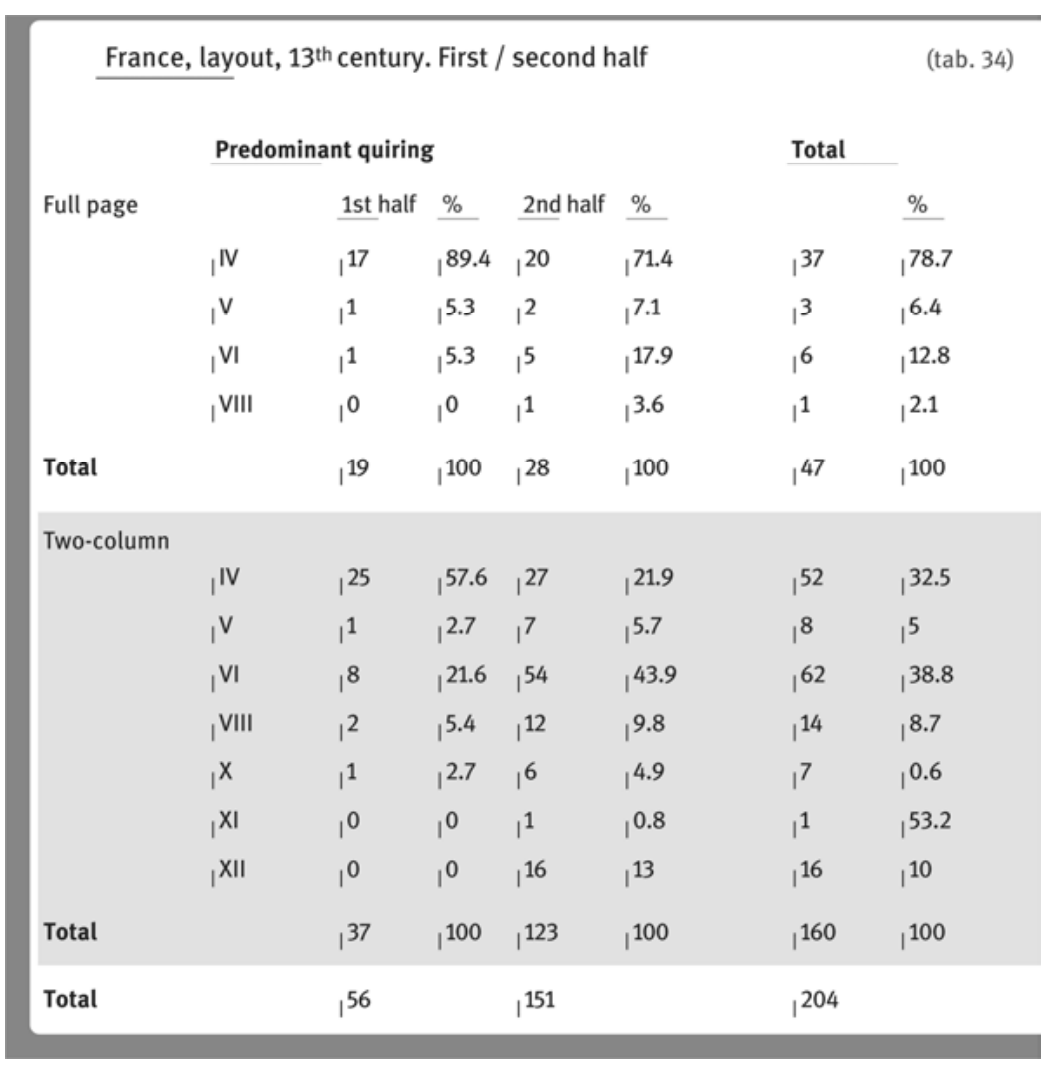

Tab. 34: France, layout, $13^{\text {th }}$ century. First / second half 


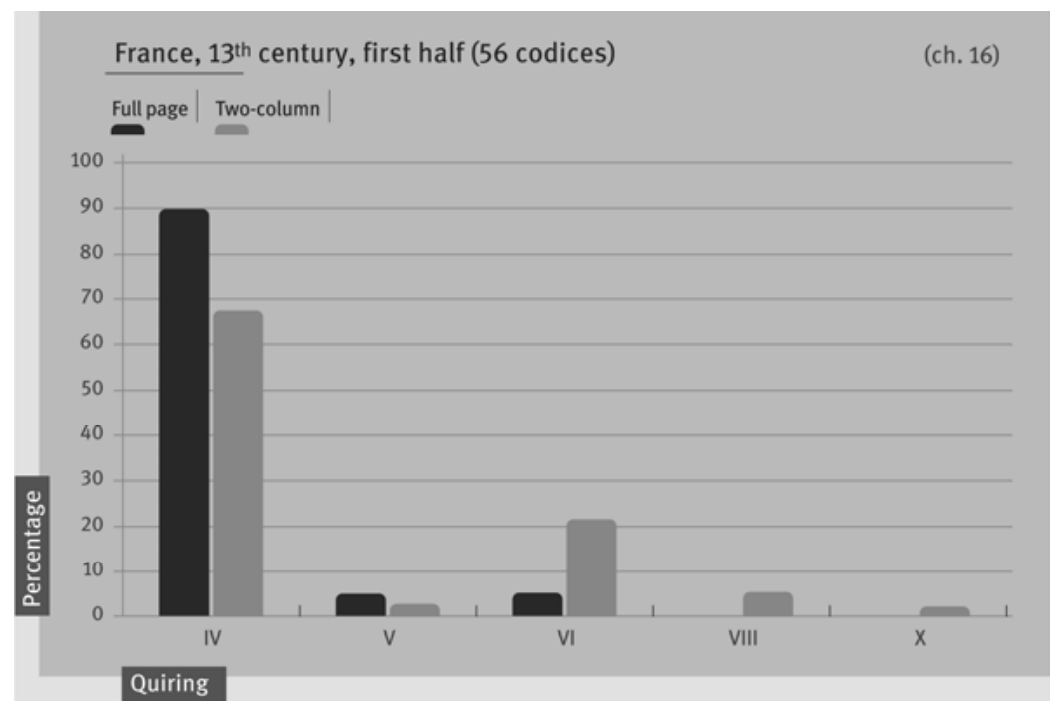

Chart 16: France, $13^{\text {th }}$ century, first half ( 56 codices)



Chart 17: France, $13^{\text {th }}$ century, second half (151 codices) 
The number of codices included in our sample that were manufactured in the first half of the $14^{\text {th }}$ century is not particularly high, and these mostly consist of volumes presenting with two-column layouts (31 instances in a total of 38). In most cases, these are structured in senions, even if examples of volumes composed of quaternions or quinions can also be observed (see Tab. 35 and Chart 18). Starting in the second half of the $14^{\text {th }}$ century, the senion is used less than the quaternion, which also tends to host two-column layouts. Nevertheless, the association typologies-full-page layout/quaternions, two-column layout/ senionsidentified earlier on, are still respected ${ }^{160}$ (see Tab. 35 and Chart 19).

\begin{tabular}{|c|c|c|c|c|c|c|c|}
\hline \multirow[b]{3}{*}{ Full page } & \multirow{2}{*}{\multicolumn{5}{|c|}{ layout, $14^{\text {th }}$ century. First / second half }} & \multirow{3}{*}{ Total } & \multirow[t]{2}{*}{ (tab. 35) } \\
\hline & & & & & & & \\
\hline & & 1st half & $\%$ & 2nd half & $\%$ & & $\%$ \\
\hline & IV & $1^{3}$ & । 42.9 & 26 & 10.3 & 29 & 65.9 \\
\hline & । & $\left.\right|^{1}$ & 14.2 & $1^{3}$ & 8.1 & $1^{4}$ & ן9.1 \\
\hline & ।VI & $1^{3}$ & $1^{42.9}$ & $1^{8}$ & $\left.\right|^{21.6}$ & $\left.\right|^{11}$ & $1^{25}$ \\
\hline Total & & $1^{7}$ & 100 & 37 & 100 & 44 & 100 \\
\hline \multicolumn{8}{|c|}{ Two-column } \\
\hline & IIV & $1^{7}$ & $1^{22.6}$ & 15 & । 40.5 & 22 & $1^{32.3}$ \\
\hline & । & $1^{4}$ & 12.9 & $1^{0}$ & $1^{0}$ & $1^{4}$ & $1^{5.9}$ \\
\hline & ¡VI & 20 & 64.5 & $\left.\right|^{21}$ & 56.8 & |41 & 60.3 \\
\hline & |XII & $1^{0}$ & $1^{0}$ & $\left.\right|^{1}$ & $\left.\right|^{2.7}$ & $\left.\right|^{1}$ & 1.5 \\
\hline Total & & 31 & 100 & |37 & 100 & | 68 & 100 \\
\hline Total & & 38 & & 14 & & 112 & \\
\hline
\end{tabular}

Tab. 35: France, layout, $14^{\text {th }}$ century. First / second half

160 In the second half of the $14^{\text {th }}$ century we find that $70.3 \%$ of full-page codices are composed of quaternions and $21.6 \%$ of senions, whilst in the case of two-column layouts $40.5 \%$ of codices are composed of quaternions, and $56.8 \%$ of senions. 


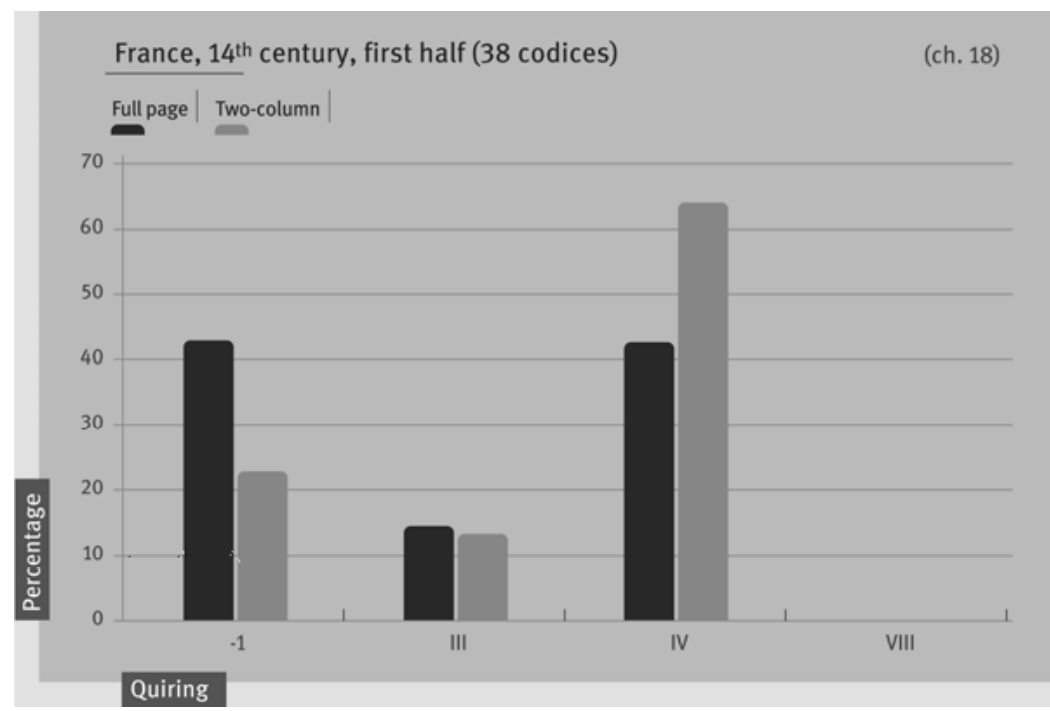

Chart 18: France, $14^{\text {th }}$ century, first half (38 codices)

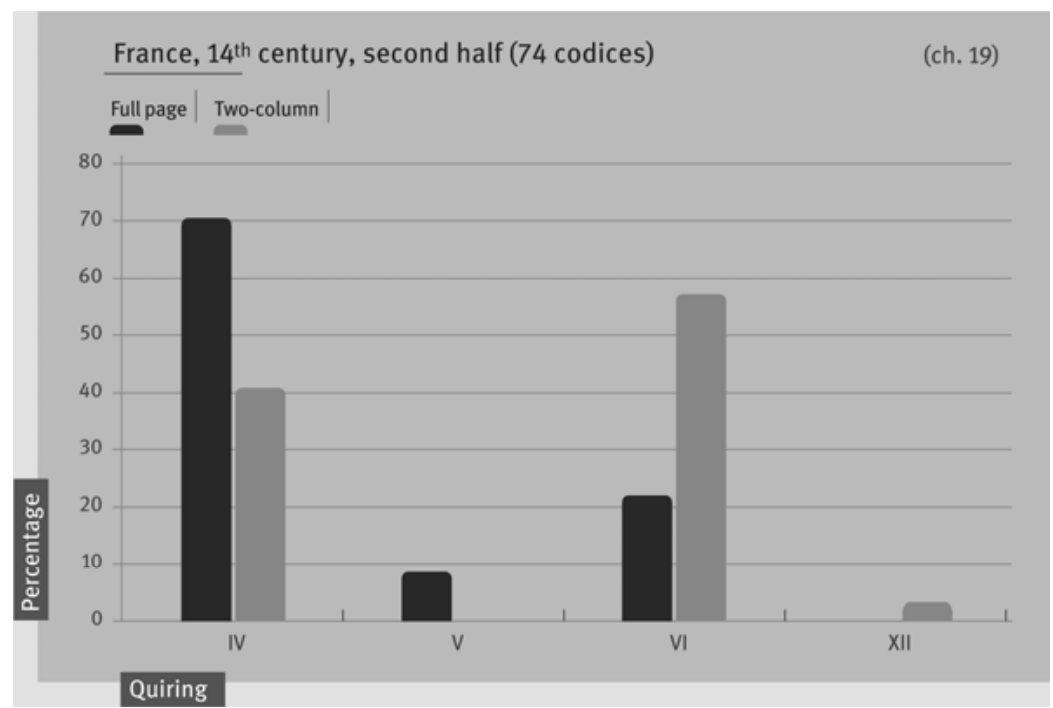

Chart 19: France, $14^{\text {th }}$ century, second half (74 codices) 


\subsubsection{Italy}

From the second half of the $13^{\text {th }}$ century ${ }^{161}$ onwards Italian manuscript production also leans towards favouring two-column layouts over full-page ones. With respect to quiring, codices with full-page layouts are, above all, composed of quaternions, whereas those with two-column arrangements show a preference for the senion. The quinion is worthy of a separate comment, since it is used as much in full-page layouts as in two-column ones, although in the latter it appears in decidedly larger numbers (see Tab. 36 and Chart 20).

\begin{tabular}{|c|c|c|c|c|}
\hline \multicolumn{4}{|c|}{ Italy, layout, $13^{\text {th }}$ century. Second half } & \multirow{7}{*}{ (tab. 36) } \\
\hline & \multicolumn{3}{|c|}{ Predominant quiring } & \\
\hline \multirow[t]{4}{*}{ Full page } & & 2nd half & $\%$ & \\
\hline & IV & 11 & $1^{55}$ & \\
\hline & ।V & $1^{3}$ & $\left.\right|^{15}$ & \\
\hline & ।VI & $1^{6}$ & $1^{30}$ & \\
\hline Total & & $1^{20}$ & 100 & \\
\hline \multicolumn{5}{|c|}{ Two-column } \\
\hline & |III & 1 & $\left.\right|^{2.6}$ & \\
\hline & IV & $1^{8}$ & $\left.\right|^{21.1}$ & \\
\hline & ।v & |10 & |26.3 & \\
\hline & ।VI & $\left.\right|^{18}$ & $1^{47.4}$ & \\
\hline & |VIII & $1^{1}$ & $\left.\right|^{2.6}$ & \\
\hline Total & & $1^{38}$ & 100 & \\
\hline Total & & 58 & & \\
\hline
\end{tabular}

Tab. 36: Italy, layout, $13^{\text {th }}$ century. Second half

161 For the first half of the $13^{\text {th }}$ century the number of items in the sample is statistically insignificant. 


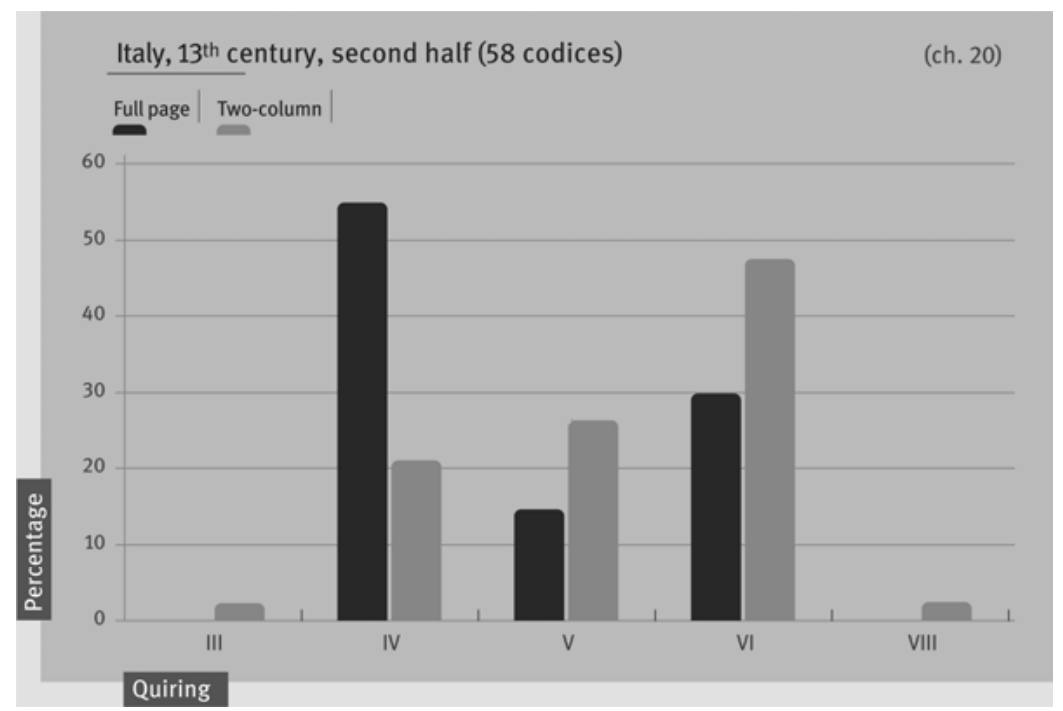

Chart 20: Italy, $13^{\text {th }}$ century, second half (58 codices)

The number of full-page codices dating from the first half of the $14^{\text {th }}$ century is not representative, given that this type of layout is totally overshadowed by the two-column one. Senion or quinion quire types appear to have been better suited-in the view of artisans and, perhaps, end users-to the layout of texts in two columns, even if the quaternion, despite being less used, still accounts for $20.7 \%$ of production (see Tab. 37 and Chart 21).

In the second half of the $14^{\text {th }}$ century there is no longer a marked discrepancy between the number of full-page codices and two-column ones, to the extent that the two options appear to be made use of equally, although two-column layouts remain the preferred option. 


\begin{tabular}{|c|c|c|c|c|c|c|c|}
\hline \multirow[b]{3}{*}{ Full page } & \multirow{2}{*}{\multicolumn{5}{|c|}{ yout, $14^{\text {th }}$ century. First / second half }} & \multirow{3}{*}{ Total } & \multirow[t]{2}{*}{ (tab. 37) } \\
\hline & & & & & & & \\
\hline & & 1st half & $\%$ & 2nd half & $\%$ & & $\%$ \\
\hline & ।III & $1^{0}$ & $1^{0}$ & $1^{1}$ & $\left.\right|^{1.8}$ & $\left.\right|^{1}$ & $\left.\right|^{1.6}$ \\
\hline & IV & $1^{2}$ & $1^{40}$ & 16 & $\left.\right|^{29.1}$ & |18 & $1^{30}$ \\
\hline & $\mathrm{l}$ & $1^{2}$ & 140 & $1^{24}$ & । 43.7 & $1^{26}$ & 143.3 \\
\hline & । $\mathrm{Vl}$ & $1^{0}$ & $1^{0}$ & $\left.\right|^{11}$ & $\left.\right|^{20}$ & $\left.\right|^{11}$ & $\left.\right|^{18.3}$ \\
\hline & ।VII & $\left.\right|^{1}$ & |20 & $1^{0}$ & $\perp^{0}$ & $\left.\right|^{1}$ & $\left.\right|^{1.7}$ \\
\hline & |VIII & $1^{0}$ & $1^{0}$ & $\left.\right|^{1}$ & $\left.\right|^{1.8}$ & $\left.\right|^{1}$ & $\left.\right|^{1.7}$ \\
\hline & IX & $1^{0}$ & $1^{0}$ & $1^{1}$ & $\left.\right|^{1.8}$ & $\left.\right|^{1}$ & $\left.\right|^{1.7}$ \\
\hline & ${ }_{1}^{x}$ & $1^{0}$ & $1^{0}$ & $1^{1}$ & 1.8 & $\left.\right|^{1}$ & $\left.\right|^{1.7}$ \\
\hline Total & & $1^{5}$ & 100 & $1^{55}$ & |100 & 160 & |100 \\
\hline \multicolumn{8}{|c|}{ Two-column } \\
\hline & II $^{\prime \prime}$ & $\left.\right|^{1}$ & 13.4 & $\left.\right|^{1}$ & $\left.\right|^{1.6}$ & $1^{2}$ & $1^{2.2}$ \\
\hline & ${ }_{\text {IV }}$ & $1^{6}$ & |20.7 & $\left.\right|^{17}$ & $\left.\right|^{27.4}$ & $\left.\right|^{23}$ & $\left.\right|^{25.3}$ \\
\hline & , v & $\left.\right|^{10}$ & | 34.5 & 32 & |51.6 & 142 & |46.1 \\
\hline & ।VI & $\left.\right|^{12}$ & | 41.4 & $\left.\right|^{11}$ & |17.8 & $1^{23}$ & $\left.\right|^{25.3}$ \\
\hline & | VIII & $1^{0}$ & $1^{0}$ & $\left.\right|^{1}$ & |1.6 & $\left.\right|^{1}$ & | 1.1 \\
\hline Total & & 29 & 100 & 62 & 100 & 91 & |100 \\
\hline Total & & $1^{34}$ & & |117 & & 151 & \\
\hline
\end{tabular}

Tab. 37: Italy, layout, $14^{\text {th }}$ century. First / second half

Both quaternions and senions are used at the same rate for full-page layouts and two-column ones, but it is clear that the quinion is becoming the preferred technical option for all manuscript production, although at this juncture it appears to be more widely used in the manufacture of codices with two-column layouts (see Tab. 37 and Chart 22). 


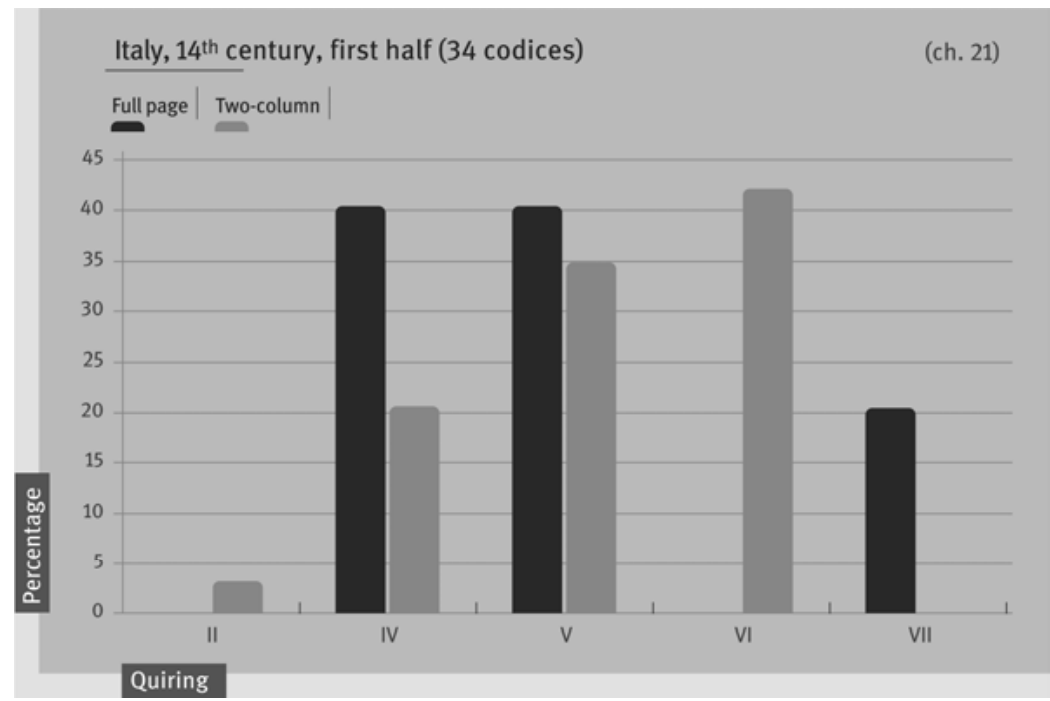

Chart 21: Italy, $14^{\text {th }}$ century, first half (34 codices)

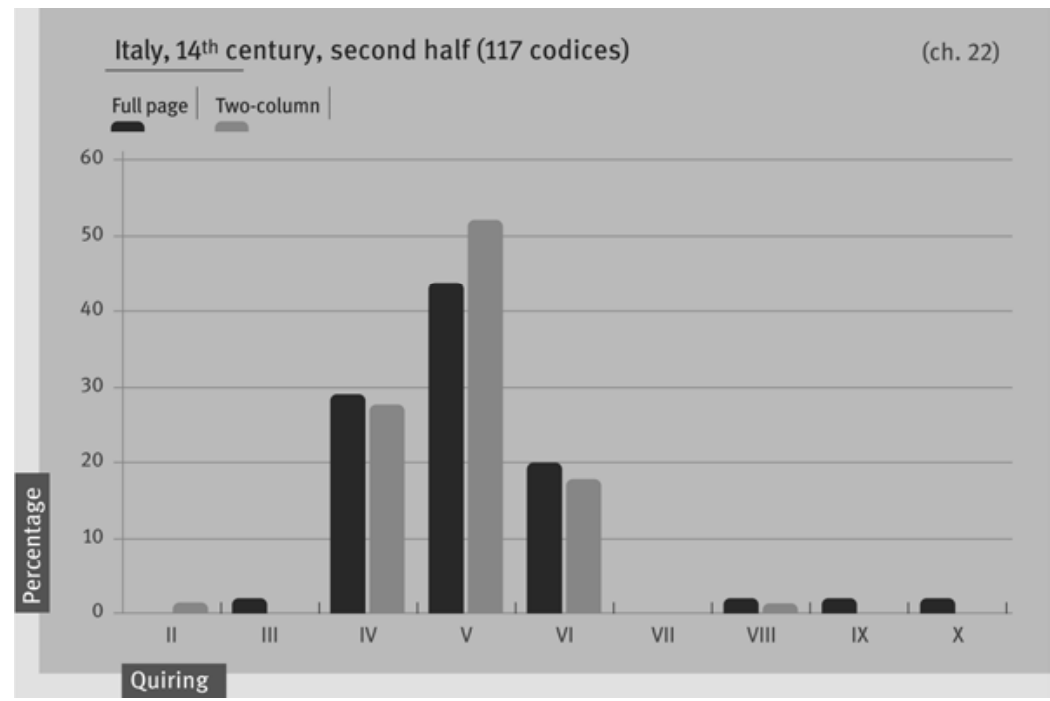

Chart 22: Italy, $14^{\text {th }}$ century, first half (117 codices) 


\subsection{Quiring and size}

It has been demonstrated that a link exists between the size of manuscripts and the layout of texts ${ }^{162}$ - up until the $14^{\text {th }}$ century, at least ${ }^{163}$-and we have already confirmed that some textual typologies go hand in hand with certain types of quire, whilst a given type of layout is more often than not associated with a specific type of quire. At this point, it is not easy to attempt to identify the mechanism lying behind the correlation between textual typology, size and layout, and no less so to associate them with quiring.

With the goal of evaluating whether or not a link exists between size and quiring, and if so, what it may be (in other words, whether the latter undergoes modifications in relation to the former), we will have to 'neutralise' all the other parameters, namely period, country of origin, textual typology and layoutwhich, as we have already established, exert an influence on quiring.

To clarify, then: if our aim is to discover the extent to which size exerts an influence on quiring, for any given period we will have to be able to isolate a sample of codices produced in one country that belong to one textual typology, and which also have the same kind of layout in common. In spite of the fact that our sample, taken as a whole, is quite large, as soon as subdivisions are made with the aim of maintaining all the variables listed above, numbers decrease so much that it becomes very difficult to draw any firm conclusions. Leaving aside the fact that, in all likelihood, the most conspicuous differences should emerge between large and small manuscripts, ${ }^{164}$ these always prove difficult to compare, since by choosing a specific textual typology from a particular period and for a given country-for example, $13^{\text {th }}$-century theological codices in England ${ }^{165}$ and France-we find ourselves looking at an essentially standard size. ${ }^{166}$

162 The 'small' manuscripts are full-page, the 'large' ones two-column.

163 Starting in the $15^{\text {th }}$ century, one begins to see very large full-page manuscripts.

164 For the sake of brevity, we shall adopt the following classes: size $<320 \mathrm{~mm}=$ small $\mathrm{manu}$ scripts, size $320 \mathrm{~mm}-490 \mathrm{~mm}=$ medium-small manuscripts, size $490 \mathrm{~mm}-670 \mathrm{~mm}=$ large manuscripts. See Bozzolo / Ornato 1980, 268.

165 With respect to England, though only with the aim of providing an example (since the reasons behind the phenomenon are difficult to explain), here we present an experiment carried out on the $13^{\text {th }}$ and $14^{\text {th }}$ centuries using theological and philosophical codices, and collections of sermons with two-column layouts. The results are summarised in Tab. 38 and 39. Maintaining all the variables cited above, it would appear that in the second half of the $13^{\text {th }}$ century the medium-large manuscripts present with a higher number of senions (90\%) than the medium-small ones (50\%). However, it should be noted that the former are far more numerous than the latter. It is clear that, no matter how much effort was made to link quiring to size in an attempt to separate the other parameters, these always exert a certain influence. In 


\subsection{Conclusions}

In carrying out this research, it has been our aim to study a particular aspect of the codex, namely quiring-which is to say the way in which the support that bears the text, be it parchment or paper, is arranged. This parameter, even if it might seem rather marginal with respect to the codex considered overall and the text that it acts as a vehicle for, is in actual fact very closely linked to the conception of the manufactured object-be it a university codex, pocket Bible, or notebook-as an ensemble of elements that contribute to the creation of a specific type of book-object conceived of in order to fulfil a primary purpose (in that it functions as a vehicle for a given message).

Therefore, the aim of our research has been to provide a picture of the various configurations that quiring assumed in the Late Middle Ages-our reasons for choosing this period for a closer study have been explained earlier on in the text-by examining the changes that led to one type of quire being favoured over another, depending on the era and context (either geographical or cultural, or both) concerned. Within this setting, we have attempted to identify the characteristics that appear to be most directly linked to quiring, and the extent to which they exerted an influence over it. Naturally, it was necessary to focus on different spans of time, depending on the variables examined.

The evolution of quiring forms a broad and multiplex panorama, hence it is difficult to describe it in brief. Therefore, given that we would like to offer the reader some useful observations, we think it will be helpful here to focus on only the most salient aspects, or at least the most characteristic ones.

Book manufacturing techniques, in particular with respect to the one that interests us here, remained essentially unchanged until the end of the $12^{\text {th }}$ century. Indeed, it is in the $13^{\text {th }}$ century that one sees a change in manufacturing solutions. This resulted from the emergence of new requirements in relation to the usability of certain texts, and therefore the use to which the manuscript would be put. The first country in which the 'symptoms' of this change are seen is England, where in the first half of the century codices composed of senions start to appear, although this type of quire only became fully established from 1250 onwards. In France, the adoption of the senion starts a few decades after its first appearance in

this case, we can hypothesise that the two-column theological volumes were in any event fabricated in the largest size, and therefore the presence of senions could be linked not so much to size, but instead to the layout chosen for that size. With regard to other periods, here we cannot add anything, because no distinct phenomenon has emerged.

166 Medium-small, and medium-large manuscripts. See footnote 164. 
England. Indeed, in the period when the senion reaches its maximum diffusion in French production, at the same time in England it has already begun its downward trajectory. In the second half of the $14^{\text {th }}$ century a reversal in the trend is seen in both countries which spurs the revival of the quaternion, a strategy that will achieve its full expression during the $15^{\text {th }}$ century.

In the second half of the $13^{\text {th }}$ century Italian production does not yet show a pronounced orientation towards a particular type of quire, although we should acknowledge the senion's not insignificant role, and likewise that of the quinion, which proves to be far more widely represented in Italy than elsewhere. Starting in the $14^{\text {th }}$ century, the use of the quinion becomes increasing widespread, until finally it prevails in all types of codex, to the extent that, whilst in the rest of Europe (with the exception of Germany) one sees the revival of the quaternion from the $14^{\text {th }}$ century onwards, in Italy manuscripts for the most part will continue to be structured in quinions up until the advent of printing.

In our sample, the number of codices produced in Germany in the $13^{\text {th }}$ and $14^{\text {th }}$ centuries is rather low, and therefore does not enable us to identify a trend, whereas in the $15^{\text {th }}$ century the senion was heavily used and became the most widely employed quire in Germany precisely at the time when its use in English and French production began to decline.

Returning for a moment to the establishment and dissemination of quiring in senions in the $13^{\text {th }}$ century, it may be just as well to remind the reader of the close link that existed between quiring and textual typology. Regardless of all the hypotheses, technical and otherwise, put forward to account for the reasons lying behind this change in the structure of the codex, the senion-which at the time of its appearance in England did not seem to be linked to a specific type of book-proves to be inextricably linked to the English and French ${ }^{167}$ university codex. In the period of its maximum diffusion (1250-1350, approximately), the senion was used, albeit to varying degrees, for virtually all textual typologies, but it is in the university context, and primarily in the theological codex, that it holds its ground even when the quaternion is once again the favoured option.

The juridical codex deserves a special mention here, chiefly where Italy is concerned. Indeed, in the second half of the $13^{\text {th }}$ century, when the quinion was still used to a lesser extent than the other quire types, the bulk of juridical production is structured in quinions. One can therefore hypothesise that the debut of the quire composed of five bifolia is linked to the juridical manuscript, a typology that would retain this structure in the centuries to come.

167 Chiefly theological codices, but also philosophical and juridical ones. 
That there exists a relationship between quiring and specific textual typologies seems undeniable. Indeed, in the case of $13^{\text {th }}$-century pocket Bibles we can venture to say that a close link exists between the function of a certain kind of book and its material execution, to the extent that the change in the concept of the Bible, which became a book to be used by individuals, coincides with a modification of its 'architecture'.

Another characteristic that we have linked to quiring (again, in the period spanning the $13^{\text {th }}$ and $14^{\text {th }}$ centuries) is the layout of the text. We have previously noted the way in which this is related to other variables, including a volume's size. Here, we will try to assemble some overall observations. We should state at the outset, however, that the said observations will be compared with the reality seen in each individual country, where the various phenomena may have manifested themselves in different ways. The correlation that we want to draw attention to here is as follows: senions are frequently employed in cases where the text is laid out in two columns, whereas a full-page layout is preferred for codices structured in quaternions. Even in England, in the second half of the $13^{\text {th }}$ century, when the use of the senions was widespread in volumes with full-page and two-column layouts, the use of quires composed of six bifolia in the latter occurred at a greater rate. Conversely, when manufacturing techniques once again shifted towards the use of quaternions-in the second half of the $14^{\text {th }}$ century-a certain tendency to associate, by preference, quaternions with full-page layouts and senions with two-column ones persisted. In French production, too, above all from the second half of the $13^{\text {th }}$ century onwards, codices with twocolumn layouts as a rule present with thick quires that contain more than six bifolia, whereas full-page manuscripts appear to be mainly composed of quaternions. In the first half of the $14^{\text {th }}$ century the most widely distributed type of codex presents with a two-column layout and is composed of senions. However, starting in the second half of the century the quaternion, accompanied by both types of layout, again reached an apogee, and even the full-page/quaternion and two-column/senion associations retain a certain relevance.

Italy presents a somewhat different landscape compared with the other countries. In fact, even if the abovementioned basic solution remains valid, we should not underestimate the role played by the quinion, which, starting in the first half of the $14^{\text {th }}$ century, is used in the making of a not negligible number of codices, above all ones with two-column layouts. In addition, in the second half of the century onwards, one encounters a very particular situation: the percentage of full-page codices quired in quaternions is not all that different from those with two-column layouts, and the same holds true for the senion, which one sees used as much for two-column layouts as for full-page ones. Instead, it is the 
quinion that, despite being widely employed in both cases, seems to be more frequently used in codices laid out in two columns.

Among the variables that we have linked to quiring is the writing support, whose usage trend presents unmistakable characteristics, to the extent that, already in the $14^{\text {th }}$ century, a clear dichotomy emerges between parchment and paper production: the former being focused on the quaternion, apart from in Italy, where the quinion also holds the upper hand with this support, whereas the latter favours the senion or quinion, or in any event, fairly thick quires. As for the $15^{\text {th }}$ century, we have examined the output of each country, and regardless of the fact that the overall trends outlined above remain steady, the technical choices made in the different countries examined were not the same. In England, the quaternion is used in both parchment and paper production, but it is precisely in the context of the latter that the senion survives, above all in the second half of the century. French production, in turn, presents a very clearly delineated picture, since codices made from parchment are for the most part composed of quaternions, whereas those made from paper lean much more towards senions, or in any event, towards fairly thick quires. As regards Italy, here we can only repeat what we have already affirmed, namely that the quinion accounts for the lion's share of manuscript production, be it in parchment or in paper, the only proviso being that in the first case one also sees the use of the quaternion, and in the second (probably on account of the 'paper effect', which we have already discussed) a good percentage of senions. Examination of production originating from the German area also reveals a very clear association between parchment and the quaternion, and paper and the senion. Indeed, the bulk of German production of the $15^{\text {th }}$ century is in paper, so it is therefore mostly structured in senions. However, as soon as one takes into account parchment-based production, quaternions once again emerge as the preferred option.

In addition, in the context of paper-based production, we have identified the link that exists between format and quiring type. ${ }^{168}$ When one looks at the European situation overall, the senion appears to be equally distributed, be it in large or small format works. On the other hand, the quaternion is seen in large format works, but it is almost absent in small format ones. For its part, the quinion, despite being represented in both large and small format books, appears to be encountered more often in the latter. Naturally, if one examines the situations seen

168 With this aim in mind, we subdivided our sample into two groups: small formats (i.e. inoctavo and in-quarto) and large formats (i.e. in-folio and large in-folio). 
in each individual country, ${ }^{169}$ different behaviours will be observed. In France, the senion is utilised in both large and small format volumes, without much difference between the two, whilst the quinion appears chiefly in in-folio and large infolio books. In the case of quaternions, one sees precisely the opposite situation: these are used in the manufacture of small format books, and seldom in large ones. We have already offered an explanation for this behaviour: the decision to use quires made from an even number of bifolia for in-quarto volumes is probably related to issues to do with efficiency, given that the making of small format volumes using quinions would have entailed a greater expenditure of energy.

Such a need to economise and rationalise the production process does not appear to have been particularly important in Italy. Indeed, despite meeting with a higher percentage of quinions in large format volumes, here we must report that almost half the output of small format works is based on quires composed of ten leaves. Senions are used in almost equal measure in both formats, whereas quaternions once again chiefly appear in in-octavo and in-quarto volumes. It should be noted that in Italy, when one considers in folio and large in folio codices separately, in the manufacture of the former, despite the fact that quinions played a predominant role, other types of quire were utilised, whereas in the latter the rate of quinion usage exceeds $80 \%$, and most of these are juridical manuscripts.

The German area shows almost no difference in the choices made with respect to the making of small and large format volumes. Broadly speaking, the senion predominates, whilst the percentage of quaternions is minimal in both groups. Quinions are also seen in more or less equal numbers in both large and small format codices.

From the picture which has emerged, it seems obvious that there exists a correlation between quire type and support, be it parchment or paper, whilst with respect to the latter, format also appears to exert a certain degree of influence on manufacturing solutions, which always reflect local ways and means.

In concluding this brief excursus, which is not exhaustive by any means, and which has the sole aim of calling to mind the various issues to be addressed by arranging them alongside each other as multiple aspects of a unitary object as it comes into being, we have to leave many questions unanswered. In any event, here we hope to have contributed to shedding some light on the historical development of an important constituent component of the manuscript, and at the same time to have kindled an interest in conducting further research.

169 With respect to England and the Low Countries, there were too few paper codices in our sample to enable us to carry out any kind of statistical analysis. 


\section{Appendix I: Surveying protocol}

\section{General information on the codex}

SHELFMARK. In the case of a composite codex, the leaves taken into consideration must be indicated.

CATALOGUE. Abbreviated reference to the catalogue.

SUPPORT. Information on the type of support is provided using the following abbreviations:

C = Paper (Italian 'Carta')

$\mathrm{P}=$ Parchment

MI = Mixed (quires made from paper with the outer or the outer and inner bifolia made from parchment).

FORMAT: The format of paper manuscripts is mentioned wherever it is indicated in the catalogue. In reality, this datum is almost always established at a later stage (during the data analysis phase), and is based on a manuscript's dimensions. ${ }^{170}$

170 In this case, we are referring to the number of folds undergone by a sheet to form the constituent bifolia of a quire, even if it must be said that the simple broad term 'format' is ambiguous, since it can be taken to mean different things. Jacques Lemaire, in his Introduction à la codicologie (Lemaire 1989) states: 'Une fois que la feuille de papier est dégagée de la forme, elle présente les dimensions délimitées par le chassis, c'est-à-dire des mesures que le papetier peut fixer arbitrairement (alors que les feuilles de parchemin offrent des surfaces variables selon la nature et la taille de l'animal). Ces dimensions définissent le format du papier suivant le premier sens que l'on attribute à ce vocable [...] Mais le mot format désigne aussi, depuis les origines de l'usage du papier, le mode du pliage que l'on fait subir aux feuillets pour constituer les cahiers d'un livre, c'est-à-dire la façon dont une feuille est pliée un certain nombre de fois en deux pour former un cahier (qui comprendra un total de feuillets équivalents à deux élevé au carré du nombre de pliages)'. The writer goes on to propose, in order to avoid any misunderstanding on account of the word's polysemy, the terms adopted by Charles and Victor Mortet: '[...] ont proposé autre fois de réserver le mot format à la designation des dimensions du papier transformé en volume, d'appeler format commercial la dimension-type du papier qui sort de la forme et format bibliographique la dimension du papier plié pour composer les cahiers' (Lemaire 1989, 34-35). In Denis Muzerelle's Vocabulaire codicologique we find two definitions for the term 'format': (a) in the section headed Pliage: 'la façon dont une feuille est plié une fois en deux pour former $2^{\mathrm{n}}$ feuillets' (Muzerelle 1985, 92); and (b), in the section headed Dimensions: 'les dimensions du volume en hauteur et en largeur' (Muzerelle 1985, 100). J. Peter Gumbert, for his part, identifies a material format: 'the fraction the leaf is of the whole sheet', an apparent format of a manuscript; 'the way its leaves are paired'; and a working format: 'the way the material was, or was not folded upon entering the 


\section{Dating, localisation, scribe}

DATING TYPE. Whether or not the dating is attested $(=\mathrm{A})$ or estimated $(=\mathrm{E})$ is indicated.

CENTURY 1. The century to which the manuscript dates is indicated in Arabic numbers.

CENTURY 2. This option is used to indicate manuscripts which straddle two centuries.

HALF-CENTURY. The half-century is mentioned using the figures 1 or 2.

QUARTER-CENTURY. The quarter-century is mentioned (if it is explicitly indicated, or readily deducible) using the figures $1,2,3,4$.

THE TERMS A QUO AND ANTE QUEM. The farthest limits of the dating are indicated, or, in cases where the codex is dated to the year, the same date is entered into each field (e.g. 1455-1455).

LOCALISATION TYPE. An attested localisation is indicated by the letter A, an approximated one by the letters (AL).

COUNTRY. The country of origin of the codex is indicated using the following initials:
A $=$ Austria
$\mathrm{B}=$ Belgium
$\mathrm{E} \quad=$ England
$\mathrm{F} \quad=$ France
$\mathrm{FN}=$ Flanders $^{171}$
$\mathrm{G} \quad=$ Germany
I = Italy
$\mathrm{H}=$ Holland
Sc $=$ Scotland

quire-which is, in essence, the sense of "format" familiar to bibliographers' (Gumbert 1993, 227244). Albert Derolez has the following to say about format: 'Le mot format est employé avec trois significations qu'il faut bien distinguer. D’abord pour indiquer la taille du livre, c'est-à-dire sa hauteur et éventuellement sa largeur, exprimables en centimetres ou millimetres (format absolu); ensuite pour exprimer la proportion entre la largeur et la hauteur du livre: ainsi on parle de format étroit, format large, format carré; nous utiliserons l'expression proportion du feuillet (PF) pour indiquer ce format relatif; finalment, on distingue le format bibliographique (in-folio, in- $4^{\circ}$, in- $8^{\circ}$, etc.), qui indiquet comment les bifeuillets des cahiers ont été obtenus par le pliage de la feuille ou de la peau)' (Derolez 1984, I, 26). A series of definitions, which broadly speaking include all the cases covered here, can be found in Maniaci 1996 (1998²), in the section headed Modalità di piegatura (127). 171 Some catalogues make specific mention of Flanders, whilst others refer more broadly to Belgium, without specifying the precise region of origin. The data were inserted in accordance with the way that they were found in the catalogues. 


$$
\begin{aligned}
& \mathrm{Sv}=\text { Sweden } \\
& \mathrm{Cz}=\text { Czechoslovakia } \\
& \mathrm{W}=\text { Wales }
\end{aligned}
$$

QUADRANT. North $(=\mathrm{N})$, South $(=\mathrm{S})$, etc.

REGION. The region where the codex was produced should be indicated in cases where it is explicitly cited in the catalogue or can be deduced.

CITY. The place of manufacture is specified, in the original language, if possible.

INSTITUTION. The place where the codex was produced is specified (e.g. the Monastery of Saint Denis).

ATTESTED SCRIBE. Whether or not the copyist is attested $(=A)$ or deduced $(=D)$ is specified.

SCRIBE'S NAME. The name of the scribe, to be transcribed in the standardised Latin form.

\section{Text}

TEXTUAL TYPOLOGY. This is indicated by means of the following initials:

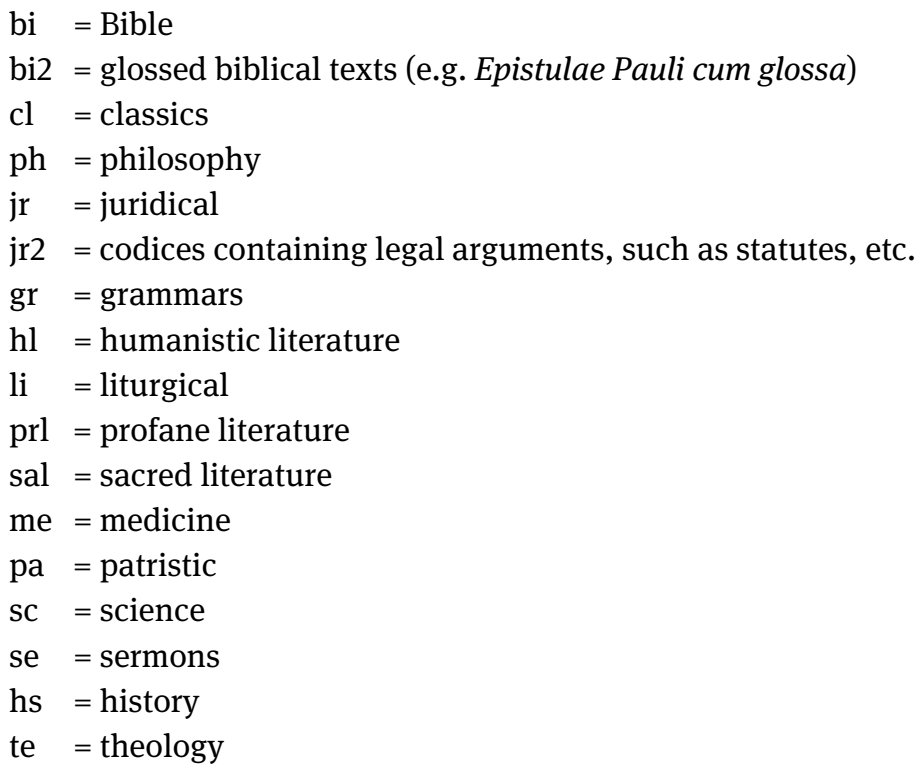

LANGUAGE OF TEXT. The language in which the text is written is specified, together with a second language, should it be present. Languages are identified as follows: 


$$
\begin{aligned}
\mathrm{fr} & =\text { French } \\
\mathrm{en} & =\text { English } \\
\text { it } & =\text { Italian } \\
\mathrm{la} & =\text { Latin } \\
\mathrm{du} & =\text { Dutch } \\
\mathrm{ge} & =\text { German }
\end{aligned}
$$

\section{Material characteristics}

NUMBER OF LEAVES. The number of leaves, excluding flyleaves.

LEAF HEIGHT. To be measured in millimetres, in common with all the other dimensions that follow.

WIDTH OF LEAF.

HEIGHT OF WRITTEN AREA.

WIDTH OF WRITTEN AREA.

FULL-PAGE/TWO-COLUMN. A full-page layout is indicated by '1', a two-column layout by '2'.

ORGANISED GLOSS. Indicate whether the codex was endowed with the possibility of having glosses added (in practice, whether or not it presents with ad hoc ruling).

NUMBER OF WRITTEN LINES.

D1. QUIRING

PREDOMINANT QUIRING. The quire type (quaternion, senion, etc.) that represents at least half of the quires in a codex is specified.

QUIRING 1. The minority quires are specified in descending order based on their thickness, or, in the absence of a predominant quire, the types of quires present, again in descending order based on their thickness.

QUIRING 2.

\section{QUIRING 3.}

QUIRE ORGANISATION. In the absence of predominant quiring, the arrangement of quire types is specified:

irr = irregular

succ = successive quires, which is to say small groups of one type of quire followed by small groups of another type of quire.

MIX = mixed, which is to say sometimes small, successive groups, and sometimes an individual quire of one type followed by another constructed in a different way.

D.2 OTHER ELEMENTS 
CATCHWORDS. The presence or absence of catchwords, based on what is explicitly recorded in catalogues, is indicated by 'yes' or 'no'. In cases where more detailed information is provided on the position or orientation of catchwords, the following initials are used:

ce $=$ centred

rt $=$ right-hand side

lt $=$ left-hand side

ve $=$ vertical

QUIRE SIGNATURES. The presence or absence of quire signatures, based on what is explicitly recorded in catalogues, is indicated by 'yes' or 'no'. Wherever possible, Derolez's number should be supplied (if it is deducible).

LEAF SIGNATURES. See above.

$A D$ HOC SIGNATURES. This specification refers to the presence or absence of internal numeration within a quire that indicates the sequence of bifolia within the same, but which does not serve to identify the position of the quire within the codex, nor to establish to which quire any erroneously positioned bifolia belong ${ }^{172}$.

RULING TECHNIQUE. The technique used for the main ruling is indicated, and where relevant, secondary ruling ${ }^{173}$, by means of the following initials:

$\mathrm{HP}=$ blind (hardpoint)

$\mathrm{P}=$ lead

I $\quad=$ ink

$\mathrm{C}=$ colour $^{174}$

FRAME RULING. Under this heading (the English term employed by Ker) details of the ruling used to create the written area are noted. This ruling consists

172 In order to clarify the notion of ad hoc signatures, we can provide an example drawn from Ker I: in the Gray's Inn 16 manuscript, the first six leaves of each quire are countermarked by the letters a-f, accompanied by a graphic symbol-depending on the case in question, this might be a vertical stroke preceding or following the leaf signatures, or a horizontal stroke, or a 'toppled' C, etc. - which indicates the quire. Derolez refers to this kind of signature as Type 5 in his classification of signatures des feuillets (Derolez 1984, I, 48).

173 Some catalogues list two kinds of ruling-lead and ink, for example-which are inserted in the survey form under the heading 'Ruling types 1 and 2'. Unfortunately, in most cases it is not made clear which of the ruling types was used for the horizontal ruling, and which for the delineation of written areas.

174 Here, the term 'colour ruling' should be taken to mean ruling carried out page by page, rather than using drypoint. The drawing medium (lead, ink, etc.) is not specified. On issues of this kind, see Canart et al. 1991, 205-225. 
in just four lines (two vertical, two horizontal) that form the frame which contains the text.

\section{Writing and decoration}

SCRIPT TYPE. The script type, as indicated by the catalogue, is reported in an abbreviated form.

PRESENCE OF ILLUSTRATIONS. If indicated by the catalogue, the presence of illustrations is mentioned.

PRESENCE OF BORDERS/FRAMING. See above.

INTIALS. Only the presence of an initial and/or the most elaborated type of initial is noted using the following abbreviations:

$\mathrm{ru}=$ rubicated

pf $=$ pen-flourished

de $=$ decorated (all the decorated initials which are not historiated are placed in this class, with a certain degree of stretching of the boundaries).

hs $=$ historiated ${ }^{175}$

HISTORY OF THE CODEX

PATRON.

CLIENT.

FIRST POSSESSOR/OWNER. Here, the first known owner (individual or institution) is reported.

DATE OF POSSESSION

MEMO. This space, as has already been stated, is reserved for various items of information which cannot be inserted into the survey form, such as remarks, observations, etc.

175 For a summarised subdivision of initials, such as the one used for this investigation, see Pace 1990, 91-101, passim, and in particular, 94-97. It should be borne in mind that the decorated initials category is regarded as being 'in opposition' to the simple and filigranated categories on the one hand, and the historiated one on the other, inasmuch as it encompasses everything that does not fit into these classes, such as zoomorphic, kaleidoscopic, figurative and populated, etc., initials. 


\title{
Appendix II: Specimen of a completed survey form
}

\author{
Survey form
}

SHELFMARK: Arras B. M. 870 (349)

CATALOGUE: M.C.L.B P.F.

FORMAT:

SUPPORT: $p$

Dating, localisation, scribe

TYPE OF DATING: $S$

CENTURY 1: 13

CENTURY 2:

HALF-CENTURY: 1

QUARTER-CENTURY:

TERMINUS A QUO:

TERMINUS ANTE QUEM:

LOCALISATION TYPE: $S$

COUNTRY: $F$

QUADRANT:

REGION:

CITY:

INSTITUTION:

ATTESTED SCRIBE:

SCRIBE'S NAME:

Text

TEXTUAL TYPOLOGY: Cl

MAIN AUTHOR: Solinus

MAIN TEXT: Collectanea rerum memorabilium

LANGUAGE OF TEXT: 1 la

PROSE OR VERSE FORM: $p$

\section{Material characteristics}

NUMBER OF LEAVES: 73

HEIGHT OF LEAF: 305

WIDTH OF LEAF: 230

HEIGHT OF WRITTEN AREA: 175

WIDTH OF WRITTEN AREA: 105

FULL PAGE/TWO-COLUMN: 1

ORGANISED GLOSS:

NUMBER OF WRITTEN LINES: 18 


\section{Quiring}

PREDOMINANT QUIRE: 6

QUIRING 1:

QUIRING 2:

QUIRING 3:

ORGANISED QUIRING:

CATCHWORDS: yes

QUIRE SIGNATURES:

LEAF SIGNATURES:

AD HOC SIGNATURES:

RULING METHOD: $1 \mathrm{i}$

FRAME RULING:

\section{Script and decoration}

SCRIPT TYPE:

PRESENCE OF ILLUSTRATIONS:

PRESENCE OF FRAMING:

MAXIMUM COMPLEXITY OF INITIALS: pe

USE OF GILDING:

History of the codex

PATRON:

CLIENT:

FIRST OWNER: Arras, Saint-Vaast

DATE OF POSSESSION: 1628

MEMO (SPACE RESERVED FOR REMARKS AND OBSERVATIONS) 


\section{References}

Beit-Arié, Malachi (1981), Hebrew Codicology: Tentative Typology of Technical Practices employed in Hebrew Dated Medieval Manuscripts, Jerusalem: Israel Academy.

Bianchi et al. (1994), 'Une recherche sur les manuscrits à cahiers mixtes', in Scriptorium, 48: 259-286.

Bianchi, Francesco et al. (1993a), 'Facteurs de variation de l'épaisseur du parchemin italien du VIII' au XV' siècle', in Maniaci, Marilena / Munafò, Paola F. (eds), Ancient and Medieval Book Materials and Techniques (Erice, 18-25 September 1992), I-II, Città del Vaticano: Biblioteca Apostolica Vaticana (Studi e Testi, 357-358), I, 95-184 (repr. in [Ornato et al.] [1997], 275-345).

Bianchi, Francesco et al. (1993b), 'La structure matérielle du codex dans les principales aires culturelles de l'Italie du XI ${ }^{\mathrm{e}}$ siècle', in Maniaci, Marilena / Munafò, Paola F. (eds), Ancient and Medieval Book Materials and Techniques (Erice, 18-25 September 1992), I-II, Città del Vaticano: Biblioteca Apostolica Vaticana (Studi e Testi, 357-358), II, 363-456.

Bischoff, Frank M. (1991), 'Pergamentdicke und Lagenordnung. Beobachtungen zur Herstellungstechnik Helmarshausener Evangeliare des 11. und 12. Jahrhunderts', in Rück, Peter (ed.), Pergament: Geschichte, Struktur, Restaurierung, Herstellung, Sigmaringen: Jan Thorbecke, 97-144.

Bischoff, Frank M. (1993), 'Observations sur l'emploi de différentes qualités de parchemin dans les manuscrits médiévaux', in Maniaci, Marilena / Munafò, Paola F. (eds), Ancient and Medieval Book Materials and Techniques (Erice, 18-25 September 1992), I-II, Città del Vaticano: Biblioteca Apostolica Vaticana (Studi e Testi, 357-358), I, 57-94.

Bischoff, Frank M. (1994), 'Systematische Lagenbrüche: Kodikologische Untersuchungen zur Herstellung und zum Aufbau mittelalterlicher Evangeliare', in Rück, Peter / Boghardt, Martin (eds), Rationalisierung der Buchherstellung im Mittelalter und in der frühen Neuzeit. Ergebnisse eines buchgeschichtlichen Seminars der Herzog August Bibliothek Wolfenbüttel $12^{\text {th }}-14^{\text {th }}$ November, 1990, Marburg: Institut für Historische Hilfswissenschaften (Elementa diplomatica, 2), 83-110.

Bischoff, Frank M. / Maniaci, Marilena (1995), 'Pergamentgröße, Handschriftenformate, Lagenkonstruktion. Anmerkungen zur Methodik und zu den Ergebnissen der jüngeren kodikologischen Forschung', in Scrittura e civiltà, 19: 277-319.

Bozzacchi, Giampiero / Palma, Marco (1985), 'La formazione del fascicolo nel codice altomedievale latino: ipotesi e verifiche sperimentali', in Scrittura e Civiltà, 9: 325-336.

Bozzolo, Carla (1994), 'La production manuscrite dans les pays rhénans au XVe siècle (à partir des manuscrits datés)', in Scrittura e Civiltà, 18: 184-242.

Bozzolo, Carla / Coq, Dominique / Muzerelle, Denis / Ornato, Ezio (1984), 'Noir et blanc. Premiers résultats d'une enquête sur la mise en page dans le livre médiéval', in Questa, Cesare / Raffaelli, Renato (eds), Il libro e il testo. Atti del convegno internazionale (Urbino, settembre 1982), Urbino: QuattroVenti, 195-221 (repr. in [Ornato, Ezio et al.] [1997], La face cachée du livre médiéval. L'histoire du livre vue par Ezio Ornato, ses amis et ses collègues. Avec une préface d'Armando Petrucci, Roma: Viella [I libri di Viella, 10], 473508).

Bozzolo, Carla / Ornato, Ezio (1980), Pour une histoire du livre manuscrit au Moyen Âge. Trois essais de codicologie quantitative, Paris: CNRS (Publications de l'équipe de recherche sur l'humanisme français des XIV et $\mathrm{XV}^{\mathrm{e}}$ siècles. Textes et études, 2). 
Busonero, Paola (1995), 'L'utilizzazione sistematica dei cataloghi nelle ricerche codicologiche: uno studio sulla fascicolazione nel basso Medio Evo', in Gazette du livre médiéval, 27: 13-18.

C.G. VI = Catalogue général des manuscrits latins. VI. (3536-3775 B) Bibliothèque Nationale, Paris, 1975.

C.G. VII = Catalogue général des manuscrits latins. VI. (3776-3835) Bibliothèque Nationale, Paris, 1988.

Canart, Paul (1980-1981), Lezioni di paleografia e di codicologia greca, Città del Vaticano: Biblioteca Apostolica Vaticana.

Canart, Paul et al. (1991), 'Recherches préliminaires sur les matériaux utilisés pour la réglure en couleur dans les manuscrits grecs et latins', in Scriptorium, 45, 2: 205-225.

Casanatense 1 = Moneti, Elena / Muzzioli, Giovanni / Rossi, Innocenza / Zamboni, Mercedes (eds) (1949), Catalogo dei manoscritti della Biblioteca Casanatense. I, Roma: Istituto poligrafico e Zecca dello Stato.

Casanatense 2 = Santovito, Emma / Ceresi, Maddalena (eds) (1956), Catalogo dei manoscritti della Biblioteca Casanatense. II, Roma: Istituto poligrafico e Zecca dello Stato.

Casanatense 3 = Ceresi, Maddalena (ed.) (1952), Catalogo dei manoscritti della Biblioteca Casanatense. III, Roma: Istituto poligrafico e Zecca dello Stato.

Casanatense 4 = Ceresi, Maddalena (ed.) (1961), Catalogo dei manoscritti della Biblioteca Casanatense. IV, Roma: Istituto Poligrafico dello Stato.

Casanatense 5 = Moricca Caputi, Ada (ed.) (1958), Catalogo dei manoscritti della Biblioteca Casanatense. V, Roma: Istituto poligrafico e Zecca dello Stato.

Casanatense 6 = Saitta Revignas, Anna (ed.) (1961), Catalogo dei manoscritti della Biblioteca Casanatense. VI, Roma: Istituto poligrafico e Zecca dello Stato.

Clairvaux = Bouhot Jean-Paul / Genest, Jean-François / Vernet, André (1997), La Bibliothèque de l'abbaye de Clairvaux du XII' au XVIII' siècle, II. Les manuscrits conservés. Première partie. Manuscrits bibliques, patristriques et théologiques, Turnhout, Brepols. ${ }^{176}$

Codici latini del Petrarca = Feo, Michele (ed.) (1991), Codici latini del Petrarca nelle biblioteche fiorentine. Mostra 19 maggio - 30 giugno 1991, Firenze: Casa editrice Le Lettere / Cassa di Risparmio di Firenze.

Colker, Trinity = Colker, Marvin L. (1991), Trinity College Library, Dublin. Descriptive Catalogue of the Mediaeval and Renaissance Latin Manuscripts, I-II, Scolar Press, Aldershot.

Daneu Lattanzi, Sicilia = Daneu Lattanzi, Angela (1965), I manoscritti ed incunaboli miniati della Sicilia, Roma: Istituto Poligrafico e Zecca dello Stato.

Derolez, Albert (1984), Codicologie des manuscrits en écriture humanistique sur parchemin, I. Texte, Il. Catalogue, Turnhout: Brepols (Bibliologia, 5-6).

Derolez, Albert (1995), 'La codicologie et les études mediévalés', in Hamesse, Jacqueline (ed.), Bilan et perspectives des études médiévales en Europe. Actes du premier Congrès européen d'études médiévales (Spoleto, 27-29 mai 1993), Louvain-La-Neuve (Fédération internationale des études médiévales. Textes et études du Moyen Âge, 3), 371-386.

Devoti, Luciana (1994), 'Aspetti della produzione del libro a Bologna: il prezzo di copia del manoscritto giuridico tra XII e XIV secolo', in Scrittura e civiltà, 18: 77-142.

176 The codicological descriptions of manuscripts collected under the letters C, F and I were consulted in draft form (thanks to the generosity of the authors) in 1993, during a visit to the IRHT in Paris. 
Di Majo, Anna et al. (1994), 'Il codice Cassinese 132 di Rabano Mauro: nota tecnica', in Cavallo, Guglielmo (ed.), Rabano Mauro, De rerum naturis. Cod. Casin. 132 / Archivio dell'Abbazia di Montecassino. Commentari, Pavone Canavese: Priuli e Verlucca, 89-98.

Filosofici 1 = De Robertis, Teresa et al. (eds) (1980), Catalogo di manoscritti filosofici nelle biblioteche. 1. Firenze, Pisa, Poppi, Rimini, Trieste, Firenze: Olschki.

Filosofici 2 = Frioli, Donatella et al. (eds) (1981), Catalogo di manoscritti filosofici nelle biblioteche, 2. Busto Arsizio, Firenze, Parma, Savignano sul Rubicone, Volterra, Firenze: Olschki.

Filosofici 3 = Garfagnini, Gian Carlo / Pagnoni Sturlese, Maria Rita / Pomaro, Gabriella / Zamponi, Stefano (eds) (1982), Catalogo di manoscritti filosofici nelle biblioteche, 3. Firenze, Pisa, Pistoia, Firenze: Olschki.

Filosofici 4 = Avarucci, Giuseppe et al. (eds) (1982), Catalogo di manoscritti filosofici nelle biblioteche, 4. Cesena, Fabriano, Firenze, Grottaferrata, Parma, Firenze: Olschki.

Filosofici 5 = Casarsa, Laura et al. (eds) (1985), Catalogo di manoscritti filosofici nelle biblioteche, 5. Cesena, Cremona, Lucca, S. Daniele di Friuli, Teramo, Terni, Trapani, Udine, Firenze: Olschki.

Filosofici 6 = Cau, Gian Mario et al. (eds) (1992), Catalogo di manoscritti filosofici nelle biblioteche, 6 . Atri, Bergamo, Cosenza, Milano, Perugia, Pistoia, Roma, Siena, Firenze: Olschki.

Filosofici 7 = Cao, Gian Mario et al. (eds) (1993), Catalogo di manoscritti filosofici nelle biblioteche, 7. Novara, Palermo, Pavia, Firenze: Olschki.

Frioli, Aldersbach = Frioli, Donatella (1990), Lo scriptorium e la biblioteca del monastero cisterciense di Aldersbach, Spoleto: Centro Italiano di studi sull'alto medioevo.

Gilissen, Léon (1977), Prolégomènes à la codicologie, Recherches sur la construction des cahiers et la mise en page des manuscrits médiévaux, Gand: Éditions scientifiques StoryScientia.

Gumbert, Johan Peter (1993), 'Sizes and Formats', in Maniaci, Marilena / Munafò, Paola F. (eds), Ancient and Medieval Book Materials and Techniques (Erice, 18-25 September 1992), I-II, Città del Vaticano: Biblioteca Apostolica Vaticana (Studi e Testi, 357-358), I, 227-263.

Haskins, Charles Homer (1972), La rinascita del XII secolo, Bologna: Mulino (Italian translation. Originally published as The Renaissance of the Twelfth Century, Cambridge: Harvard University Press 1927).

Irigoin, Jean (1998), 'Les cahiers des manuscrits grecs', in Hoffmann, Philippe (ed.), Recherches de codicologie comparée. La composition du codex au Moyen Âge, en Orient et en Occident, Paris: Presses de l'École Normale Supérieure, 1-19.

Ker I = Ker, Neil R. (1969), Medieval Manuscripts in British Libraries. I. London, Oxford: Clarendon Press.

Ker II = Ker, Neil R. (1977), Medieval Manuscripts in British Libraries. II. Abbotsfield-Keele, Oxford: Clarendon Press.

Ker III = Ker, Neil R. (1983), Medieval Manuscripts in British Libraries. III. Lampeter-Oxford, Oxford: Clarendon Press.

Ker IV = Ker, Neil R. / Piper, Alan J. (1992), Medieval Manuscripts in British Libraries. IV. PaisleyYork, Oxford: Clarendon Press.

Kuttner I = Kuttner, Stephan / Elze, Reinhard (1986), A Catalogue of Canon and Roman Law Manuscripts in the Vatican Library, I. Codices Vaticani latini 541-2299, Città del Vaticano: Biblioteca Apostolica Vaticana (Studi e Testi, 322).

Kuttner II = Kuttner, Stephan / Elze, Reinhard (1987), A Catalogue of Canon and Roman Law Manuscripts in the Vatican Library. II. Codices Vaticani Latini 2300-2746, Città del Vaticano: Biblioteca Apostolica Vaticana (Studi e Testi, 328). 
Le Goff, Jacques (1979), Gli intellettuali nel medioevo, Milano: Mondadori.

Lemaire, Jacques (1989), Introduction à la codicologie, Louvain-La-Neuve, Université Catholique de Louvain (Publications de l'Institut d'études médiévales. Textes, Études, Congrès, 9).

Leonardi, Vaticani = Codices Vaticani Latini 2060-2117, recensuit Claudius Leonardi operam dante Maria Magdalena Lebreton, indicibus instruxerunt Ambrosius M. Piazzoni et Paulus Vian, Città del Vaticano: Biblioteca Apostolica Vaticana, 1987.

Light, Laura (1987), 'The New Thirteenth-Century Bible and the Challenge of Heresy', in Viator. Medieval and Renaissance Studies, 18: 275-288.

Light, Laura (1994), 'French Bibles c. 1200-30: a New Look at the Origin of the Paris Bible', in Gameson, Richard (ed.), The Early Medieval Bible. Its Production, Decoration and Use, Cambridge: Cambridge University Press, 155-176.

Lowe, Elias Avery (1934-1966), Codices Latini Antiquiores. A Palaeographical Guide to Latin Manuscripts Prior to the Ninth Century. Oxford, The Clarendon Press.

M.C.L.B.P.F. = Jeudy, Colette / Riou, Yves-François (1989), Les manuscrits classiques latins des bibliothèques publiques de France, I. Agen-Évreux, Paris, CNRS.

Maier, Vaticani Burghesiani = Maier, Anneliese (1952), Codices Burghesiani Bibliothecae Vaticanae, Città del Vaticano: Biblioteca Apostolica Vaticana (Studi e Testi, 170).

Maniaci, Marilena (1996 [1998²]), Terminologia del libro manoscritto, Milano, Roma: Istituto centrale per la patologia del libro.

Munk Olsen, Birger (1982-1989), L'étude des auteurs classiques latins au Xle et XII siècles, 4 vols, Paris: CNRS.

Muzerelle, Denis (1985), Vocabulaire codicologique. Répertoire méthodique des termes français relatifs aux manuscrits. Paris: CEMI (Rubricae. Histoire du livre et des textes, 1).

Mynors, Balliol = Mynors, Roger A. B. (1963), Catalogue of the Manuscripts of the Balliol College Oxford, Oxford: Clarendon Press.

Ornato, Ezio (1997), 'La codicologie quantitative, outil privilégié de l'histoire du livre médiéval', in Ornato, Ezio et al., La face cachée du livre médiéval. L'histoire du livre vue par Ezio Ornato, ses amis et ses collègues. Avec une préface d'Armando Petrucci, Roma: Viella (I libri di Viella, 10), 375-402.

Orsatti, Paola (1993), 'Le manuscrit islamique: caractéristiques matérielles et typologie', in Maniaci, Marilena / Munafò, Paola F. (eds), Ancient and Medieval Book Materials and Techniques (Erice, 18-25 September 1992), I-II, Città del Vaticano: Biblioteca Apostolica Vaticana (Studi e Testi, 357-358), II, 269-331.

Pace, Valentino (1990), 'Miniatura e decorazione dei manoscritti', in Jemolo, Viviana / Morelli, Mirella (eds), Guida a una descrizione uniforme di manoscritti e al loro censimento, Roma: ICCU, 91-102.

Palma, Marco (1988), 'Modifiche di alcuni aspetti materiali della produzione libraria latina nei secoli XII e XIII', in Scrittura e civiltà, 12: 119-133.

Palma, Marco (1994), 'La struttura fisica degli Exultet' in Cavallo, Guglielmo (ed.), Exultet. Rotoli liturgici del medioevo meridionale, Roma: Istituto Poligrafico e Zecca dello Stato, 39-51.

Parkes, Malcom Beckwith (1979²), English Cursive Book Hands, 1250-1500, Hampshire: Taylor \& Francis.

Rizzo, Silvia (1973), Il lessico filologico degli Umanisti, Roma: Edizioni di Storia e Letteratura. Saenger, Newberry = Saenger, Paul (1989), A Catalogue of the Pre-1500 Western Manuscript Books at the Newberry Library, Chicago/London: The University of Chicago Press. 
Sirat, Colette (1998), 'Pour quelle raison trouve-t-on au Moyen Âge des quinions et des quaternions? Une tentative d'explication', in Hoffmann, Philippe (ed.), Recherches de codicologie comparée. La composition du codex au Moyen Âge, en Orient et en Occident, Paris: Presses de l'École Normale Superieure, 131-135.

Supino Martini, Paola (1992), 'Le sottoscrizioni testimoniali al documento italiano del secolo VIII: le carte di Lucca', in Bullettino dell'Istituto storico italiano per il medio evo, 98: 87108.

Thurn, Würzburg II.2 = Thurn, Hans (1986), Die Handschriften der Universitätsbibliothek Würzburg. II.2, Wiesbaden: Harrassowitz.

Thurn, Würzburg II.I = Thurn, Hans (1973), Die Handschriften aus benediktinischen Provenienzen. Il.1, Wiesbaden: Harrassowitz.

Tomiello, Antonella (1992-1993), 'Per un esame della scrittura testuale italiana : la cosiddetta "littera bononiensis". PhD thesis, Università degli studi di Padova.

Turner, Eric Gardner (1977), The Typology of the Early Codex, Philadelphia: University of Pennsylvania Press (Hanley Foundation Series, 18).

Vézin, Jean (1998), 'Les cahiers dans les manuscrits latins du haut Moyen Âge', in Hoffmann, Philippe (ed.), Recherches de codicologie comparée. La composition du codex au Moyen Âge, en Orient et en Occident, Paris: Presses de l'Ecole Normale Superieure, 99-104.

Wilmart, Vaticani = Wilmart, André (1937), Codices Reginenses latini. I. Codices 1-250, in Biblioteca Apostolica Vaticana.

Zamponi, Manoscritti petracheschi = Zamponi, Stefano (1984), I manoscritti petracheschi della Biblioteca Civica di Trieste. Storia e Catalogo. Padova, Antenore (Censimento dei codici petracheschi, 8).

Zappella, Giuseppina (1994), 'Il fascicolo nella struttura del libro antico', in Accademie e Biblioteche d'Italia, 1: 17-60.

* Busonero $=$ Busonero, Paola, teologici

* Devoti $=$ Devoti, Luciana, giuridici

* Notices $=$ Notices

The final three entries, marked with an asterisk, are not printed catalogues. The first entry refers to a corpus of 18 theological and philosophical codices drawn from the third volume of the Catalogue des manuscrits datés, which was scrutinised in person by the author. The second is composed of 16 juridical manuscripts (held in French and Italian libraries). Their descriptions were kindly supplied by Luciana Devoti, who personally examined them while carrying out a research project on glossed juridical manuscripts (published in the present volume). The Notices are descriptions of manuscripts, still in hand- or typewritten form, compiled by various authors (among whom we should mention Élizabeth Pellegrin) and held by the Institut de Recherche et d'Histoire des Textes in Paris. 
